Tarih Kültür ve Sanat Araştırmaları Dergisi

Revue des Recherches en Histoire Culture et Art مجلة البحوث التاريخية و الثقافية و الفنية
Vol. 7, No. 5, December 2018

Copyright (C) Karabuk University

http://kutaksam.karabuk.edu.tr

\title{
DOI: 10.7596/taksad.v7i5.1889
}

Citation: Üçler, F. (2018). Psikiyatrik Vakalardan Esinlenen Edebi Eserlerde Kadın Karakterler Üzerine Bir Inceleme. Journal of History Culture and Art Research, 7(5), 687-725.

\section{Psikiyatrik Vakalardan Esinlenen Edebi Eserlerde Kadın Karakterler Üzerine Bir İnceleme*}

\section{An Investigation on Female Characters in Literary Works Inspired by Psychiatric Cases}

Fatma Üçler ${ }^{1}$

\begin{abstract}
The aim of this study is to evaluate the text of psychiatric cases from a literary perspective. Based on the stories and therapies of her patients, Gülseren Budayıcıoğlu who is a psychiatrist presents them to the reader in her short stories and novel fictions. We will subject the works based on female characters to literary analysis. The author's first work, Madalyonun lçi, consists of short stories. The second work, Günahın Üç Rengi, basically contains three main stories. His third work, Hayata Dön, despite being a novel, displays cases of patients. In these works, the author reveals his identity as a doctor and the perception of reality is always open. The fourth work, Kral Kaybederse, is a technical novel fiction. In every work, woman is in the foreground. In her works, the effects of the damage on the psychology of the women and, as a psychiatrist, the authors' approach to the problems and his guidance to the women on how to deal with these problems are included.
\end{abstract}

Keywords: Psychological novel, Psychotherapy, Psychoanalysis literature, Women, Gülseren Budayıcıoğlu.

\footnotetext{
* Bu makale, 4-5 Ekim 2018 tarihinde, İzmir'de 2. Uluslararası Kadın Kongresi'nde sunulan bildirinin genişletilmiş hâlidir.

${ }^{1}$ Kocaeli Üniversitesi, Türk Dili Bölümü, Öğretim Görevlisi, Türkiye. E-mail: fatma.ucler@kocaeli.edu.tr
} 
Bu çalışma, edebiyatı psikanalitik açıdan değerlendirmek yerine; psikiyatrik vakalardan oluşan metni, edebî açıdan değerlendirmek amacındadır. Psikiyatrist Dr. Gülseren Budayıcıoğlu, hastalarının hikâyelerinden ve terapilerinden yola çıkarak öykü ve roman kurmacası içinde bunları okuyucuya sunmaktadır. Eserleri, kadın karakterlerini esas alarak edebî çözümlemeye tabi tutacağız. Yazarın ilk eseri Madalyonun Içi, kısa kısa öykülerden oluşur. İkinci eser Günahın Ü̧̧ Rengi, temelde üç esas öykü barındırır. Üçüncü eseri Hayata Dön, romandır yine de içinde, kısa hasta vakaları yer alır. Bu eserlerde yazar, Doktor kimliğini açık eder, gerçeklik algısı daima açıktır. Dördüncü eser Kral Kaybederse'de teknik roman kurgusu oluşmuştur. Her eserde ön planda olan kadındır. Eserlerdeki kadınların aldığı hasarların psikolojilerine nasıl etki ettiği, yazarın psikiyatr olarak sorunlara yaklaşımı ve kadınlara, bu sorunlarla nasıl baş edebilecekleri konusunda yol göstericiliğini içerir.

Anahtar Kelimeler: Psikolojik roman, Psikoterapi, Psikanaliz, Edebiyat, Kadın, Gülseren Budayıcıoğlu.

\section{Giriş}

Edebiyat, pek çok sosyal bilim alanından beslenerek ilerleyen, kendini geliştiren ve dönüştüren bir sanat dalıdır. Özellikle psikoloji edebiyatı doğrudan etkiler. Çünkü edebî türler içinde bilhassa roman ve öyküde kişiler büyük öneme sahiptir. Kişilerin yaratı süreci, yazarın edebî ve gözlem gücü ile orantılıdır. Başarılı addedilen hikâye ya da romanların kişilerine baktığımızda bu gücü görebiliriz. Kurmaca dünyanın kişileri bazen gerçek dünyadakilerden seçilir. Burada ise gerçeğin kurguya uygunluğundan bahsedilebilir. Yazarların gerçeklik algısı yaratabilmesi için, insanı tanımada, oluşturmada bu bilim dalından faydalanması kaçınılmazdır.

Bu çalışmamızda, iki roman, iki öykü kitabı bulunan Psikiyatr Gülseren Budayıcıoğlu'nun eserlerindeki kadın karakterler üzerinde duracağız. Söz konusu eserler kurmaca dünyaya ait olsa bile, yazar tarafından gerçek hikâyelerden oluşturulduğu bilgisi ile yayımlanmıştır. Biz de bu doğrultuda çok çeşitli psikolojik nedenlerle kliniğine gelen hastaları, fiktif kişi hâline getiren yazarın kadın tipolojisini çıkarmaya çalışacağız. Çalışmada üzerinde durduğumuz nokta; hem Türk kadınının ne gibi sebeplerle psikolojik hasar aldığını ya da verdiğini göstermek, hem de bir doktorun tababet ile edebiyat örüntüsünü nasıl kurduğuna dair edebî bir inceleme yapmaktır.

Madalyonun İçi adlı kitapta on beş öykü bulunmaktadır. Bu öykülerde çeşitli hâlleri ile Türk kadınının psikolojisini, kafasının içini bir psikiyatr gözüyle görmekteyiz. Birbirinden bağımsız olsa da kadının varlığı, sağlığı öykülerde önemli bir şekilde vurgulanmaktadır. Günahın Ü̧̧ Rengi adlı eser de yine öykülerden oluşmaktadır. Olaylara müdahil, etkin ya da pasif konumu ile özellikle cinsel yaşantıda önemli yere sahip olan kadınlar, eserde anlatılı̆̆ı kadar tanıtılıp değerlendirilecektir. Hayata Dön, adlı eserde, hayata dair tüm umudunu yitirmiş varlıklı bir genç kızın, doktor ${ }^{2}$ ve kadın dayanışması ile nasıl hayata döndürüldüğü anlatılmaktadır, ancak burada dikkat çeken başka husus, hayata döndürülmeye çalışılan kişiye en büyük zarar yine bir kadından, "anne" den gelmiştir. Kırsalda kadın baskısı, kalabalık ailede kadının rolü bu eserin kadınlara dair başka bir yönünü gösterir. Yazarın Kral Kaybederse adlı romanında temel olarak üç kadın dikkat çeker: Aldatılan kadın, çok sevilen metres ve kadınlara düşkün bir erkeğin annesi. Bunların hepsi çok farklı kişiliktedirler. Burada onları aynı öyküde buluşturan bir erkektir. Ne var ki hepsinin ayrı kişilikte olması gibi ayrı ayrı yaraları da mevcuttur. Bunlar haricinde eserde pek çok kadın figürü de ayrıca bahis konusu olacaktır.

\footnotetext{
${ }^{2}$ Metin içinde geçen “Doktor” kelimesi, aksi belirtilmediği sürece, Psikiyatrist Doktor Gülseren Budayıcıoğlu’nu anlatmak için kullanılmıştır.
} 
Hayattan çeşitli açılardan yaralar almış kadınların bu hâline doğrudan ya da dolaylı bir şekilde sebep olanlar, bu kadınların hayata karşı duruşu, bir kadın olan doktorun onlara hayatla mücadele etmeyi öğretmesi eserlerin omurgasını oluşturmaktadır.

Eserler bir kadın yazar tarafından yazıldığı için, ayrıca eser içinde kadına yönelik pek çok erkek görüşü hâkim olduğu için feminist okumaya müsaittir. Eserin bu yönünü, salt kuramsal okumayla değil, bölümler içinde, kadına bakış açılarını göstermeye çalışırken belirttik.

Sartre, "Yazarın, insanlar bu yoldan çıkarılacak nesne karşııında bütün sorumluluklarını yüklenebilsinler diye dünyayı ve özellikle de insanoğlunu öteki insanlara açıkça göstermeyi seçtiğini söyleyebiliriz. (...) Yazarın görevi de hiç kimsenin dünyadan habersiz kalmamasını ve bu yüzden kendisinin suçsuz olduğunu ileri sürememesini sağlamaktır." (1982: 31) görüşünü temel alarak, yazarın, hastaların ona aktardıklarına kendi birikimini de katarak okuyuculara sunduğunu iddia edebiliriz. "Demek ki yazmak hem dünyanın üstündeki örtüleri kaldırmak, hem onu okuyucunun cömertliğinin karşısına görev gibi çıkartmaktır. (...) Şu dünyanın haksızlıklarıyla birlikte önüme getirilişi, bu haksızlıkları soğukkanlılıkla seyredeyim diye değil, tiksintimle canlandırayım, üstlerindeki perdeyi kaldırayım ve onları birer haksılık, yani yok edilmesi gereken- yolsuzluklar olarak yaratayım diyedir. Böylece yazarın evreni ancak okuyucunun incelemesi, hayranlığı, tiksinmesi sonunda tüm derinliğiyle ortaya çıkacaktır ..." (Sartre, 1982: 60-62). Budayıcıoğlu da yazarken tam da bu işi yapar. Kitaplarını, herhangi bir doktora gidemeyen kişilerin kendi kendilerini tanıyıp, kaderlerini sorgulamak için kaleme aldığını bildirir. Ancak o, dünyanın üstündeki örtüleri kaldırma işini, sadece ve ilk olarak eserlerinde yapmaz, önce hastaları ile terapi seanslarında, sonra okuyucularına karşı yapar. Öte yandan evreni okuyucuya sunarken sadece hayal gücü ve gözlemini değil, kaderin ve gerçek kişilerin oluşturduğu hayatlardan kaynak alarak oluşturmuştur.

Karl Gustav Jung "Psikoloji ve Edebiyat" adlı yazısında, "Psişik süreçlerin incelenmesinden başka bir şey olmayan psikoloji, edebiyatın incelenmesi konusuna da el atabilir; çünkü insan ruhu (psyche) bütün bilimlerin ve sanatların kaynağıdır. (...) Sanat eserini incelemek söz konusu olunca, karmâşık psişik faaliyetlerin ortaya çıkardığı bir ürünü ele almamız gerekiyor demektir." (1981: 53) yorumlarında bulunmaktadır. Burada incelediğimiz romanlar ve bu çalışma ise Jung'un söylediklerinin aksini ele almaktadır. Yani psikoloji edebiyatı değil, edebiyat psikolojiyi ele almaktadır. Yazar roman ve öykülerinde Jung'un ifade ettiği gibi, insan ruhunu sanatın temeline oturtmuştur. Kurmacadan ziyade gerçeği edebiyata çeviren Doktor bize edebiyat içindeki psikolojiyi değerlendirme fırsatı tanımıştır. Bu bakımdan okuyucular ve araştırıcılar, psikoloji ve edebî yaratıyı bu eserlerde iç içe bulabilmektedirler.

\section{Yöntem}

Bu araştırmada, Gülseren Budayıcıoğlu'nun dört eseri, eleştirel okumaya tabi tutuldu. Berna Moran, Edebiyat Kuramları ve Eleştiri eserinin Önsöz'ünde "Bir sanat olayında rol oynayan dört unsur vardır: Sanatçı, eser, okur ve bunların içinde bulunduğu dı̧̧ dünya (toplum)." (2004: 9-10) der. İncelememizde, söz konusu eserleri, kuramsal olarak tek bir bakış açısı ile ele almasak da, genel esere yönelik okuma yapıldı. Ayrıca, okumalar kadın açııından değerlendirilerek feminist okuma kuramı ile daha çok ilişkilendirilmiştir. Bunun yanı sıra psikolojik alt yapı ile yazılan bu eserler, psikanalitik alandaki temel eserlerle desteklenerek, kadın, aile, psikoloji gibi yan dallar ile ilişkilendirilerek incelenmiştir. Özellikle kadın kimliğinin belirgin olduğu bu eserlerde, kadın tiplerinin hangi yönleri ile ön plana çıktığı vurgulanmıştır. 


\section{Eserler}

\section{1. Öyküler}

\section{1. Madalyonun $i_{c ̧} i^{3}$}

Yazarın ilk kitabı olan bu eser, 12 kısa, 4 uzun öyküden oluşmaktadır. Bu dört öykü tek seferde okuyucuya sunulmamış her biri parçalar hâlinde, başlıkları numaralandırılarak 12 öykü arasına serpiştirilmiştir. Bölümler hâlindeki dört öykü uzundan kısaya doğru incelenecektir. Diğerleri ise eserdeki sıraya göre değerlendirilecektir.

1. "Çöp Apartmanı”: Bu öykü, birbirinden farklı sorunlara sahip üç kız kardeşi ve onları bu hâle getiren annelerini ele alır. Üç kız kardeş ve babaları, kendilerine ait bir apartmanın bir dairesinde yaşamaktadır. Gülben otuzlu yaşlardadır, gece altını ıslatma sorunu vardır. Doktora bu sebeple, zorla gelir, tedaviye yanaşmaz, verilen ilacı kullanmaz. Ayrıca oldukça ketumdur. Ondan sonra kız kardeşi Neriman Doktora gelir. Normal bir ailesi olmadığını bilir, önce kendi sonra kız kardeşleri için yardım almak ister. Neriman evdeki tek çalışandır, dış işlerle uğraşır, ancak evde temizlik hastası iki ablası ve hasta bir babası vardır. Onların bakımını, evin temizliğini yapar, Temizlik oldukça sıra dışıdır. Eller on kere sabunlanır, defalarca durulanır. Yemek yaparken bile her bir fasulye tek tek sabunlanır öyle pişirilir. Mutfak eşyaları, kıyafetler makineye girmeden önce elde üç kez sabunlu, üç kez duru suda yıkanır öyle makineye konulur. Çöplerin de ayrı hikâyesi vardır. Çöpe atılacak her şey tek tek incelenip öyle poşete konur, yine de gözden kaçan bir şey olursa diye poşet çöpe atılmaz, tekrar kontrol edilmek üzere odalara konur. Evde çöp koyacak oda kalmayınca kiracılar çıkarılır ve boş daireler çöp biriktirmek için kullanılır. Böylece apartman, çöp apartmanına dönüşür. Gülben'in gece ıslattığı çarşaflar bile yıllardır böyle istiflenmiştir. Neriman tedaviye açıktır, kendini ve ailesini kurtarmak ister. İ̧ yerinden bir genç onu sever, istemeye gelirler ancak ablaları bu evliliği istemez. O günden sonra Neriman'a daha çok yüklenirler. Neriman ablalarına ve babasına bakmak için işten ayrılır ve çok yıpranır. Nihayetinde baba hastanelik olur. Neriman babasının yanında kalmak zorundadır. İki kız kirlenme korkusu ile ne yemek pişirebilir ne su içebilirler. Neriman Doktora başvurur ve Doktor bunu, acil durum olarak değerlendirip iki kız kardeşi görmek için eve gider. En büyük abla Safiye Doktora çıkışır, onu reddeder. Ancak Doktor ilk seferinde onun direncini kırmayı başarır. Aile içinde en büyük yarayı Safiye almıştır. Bu yüzden de en büyük travma onunkidir. Annesinden hiçbir zaman sevgi, şefkat görmemiştir. Hatta annesi, ona uğursuz olduğunu defalarca söylemiştir. İlk çocuk olmanın zorluğunu daima sırtında taşımıştır. Annesi onu ve diğer kızlarını 'oğlan olmadıkları için' hiç sevmemiştir. Hatta kız bebeklerle ilgilenmediği için bebekler ilgisizlikten ölmüştür. Kocasının onu oğlan doğuramadığı için sevmediğini zanneder. Safiye anneannesinin içini döktüğü kişidir. Ondan annesiyle ilgili pek çok şey öğrenmiş ve bunları ömür boyu sır olarak saklamıştır. Annesi oldukça titiz, sinirli ve kuralcıdır. 26 yaşına kadar iki kere nişanlanmış ayrıımıştır. En sonunda kızların babası ile evlenmiştir. Ancak birbirlerini hiç sevmemişlerdir, bundan en büyük hasarı da çocuklar almıştır. Babanın daha önce sevdiği neşeli, konuşkan, sıcak ve herkesin sevdiği bir karısı ile oğlu vardır, ancak trafik kazasında ikisi de ölür. íkinci evliliği ise sadece mutsuzluk getirir. Adam evi kirletme korkusuyla içeri zor girmektedir. Bu yüzden de kendini işe verir. Çocukları ile hiç ilgilenmez. Anne ilk kız Safiye ile sürekli psikolojik ve fiziksel çekişme hâlindedir. Safiye liseye giderken komşularının oğlu Mehmet'le plâtonik aşk yaşarlar. Anne bunu fark edince Safiye'yi daha çok ezer. Doğum gününde Mehmet yolda Safiye'ye bir hediye vermek ister, annesini gören Safiye, oğlana uzaklaşmasını söyler, o anda otobüs oğlana çarpar ve oğlan ölür. Annesi Safiye'yi eve sürükleyip dövmeye başlar, kemiklerini kırıncaya dek döver, Safiye dayak yedikçe rahatladığını söyler (!) bu yüzden annesini kışkırtır. Anne bu dayak esnasında ilk kalp krizini geçirir. Safiye ambulansı çă̆ırıp annesini kurtarır. Hastanede polisler durumu sorunca da kaza olduğunu söyler ve ikinci kez annesini kurtarır. Ama annenin zulmü bitmez, hem Mehmet'in ölümünden, hem kendi hastalı̆ından yaşadığı her an Safiye'yi

\footnotetext{
3 ilk baskısı 2003 yılında yapılmıştır.
} 
sorumlu tutar, üstelik Safiye annesine bakmak için okulunu bırakmıştır. Olanları ne baba ne kardeşler sorar, hepsi de annenin yaptıklarından haberdardır. Anne ölürken bile Safiye'ye vicdan azabı yükleyip ölür, son sözleri “ Öbür tarafta iki elim yakanda olacak, yaptıkların yanına kâr kalmayacak !" olmuştur. Sırf bu yüzden Safiye intihar etmekten bile vazgeçmiştir. Kendini daima suçlu hisseder. Annesinin sinirliliğine ve titizliğine kızmasına rağmen kendisi de kız kardeşlerine bu şekilde davranır hatta annenin küçümseyici bir şeklide kızlara taktığı lâkaplarla seslenir. Safiye Doktorla konuştukça açılır, suçluluk duyguları hafifler, kirlenme korkusu ile yemek, tuvalet, yıkanma ihtiyaçlarından bile kendini mahrum bırakırken yavaş yavaş hayata adapte olmaya başlar. Tedaviye en dirençli ablanın bu tavrı kızlar üstünde de olumlu etki yapar. Gülben gece ıslatmalarını keser, hasta olduklarına ikna olurlar ve hepsi ilaçlarını düzenli kullanırlar. Nihayet evden çıkma cesaretini gösterip ölmeden önce babalarını görürler. Bu son görüşme onların terapisinde büyük yer eder, kendilerini sevmediklerini zannettikleri babaları onları çok sevdiğini söyler. Hayatları düzene girmeye başlar. Tedaviden sonra artık her şey, oturdukları semt bile değişmiştir. Yeni eşyalar, yeni ev ve yeni bir hayat başlamıştır. Eskiden kir dolu bir evde temizlenmeye çalışan, hiç konuşmayan, iletişim şekli olarak kavgayı tanıyan kızlar uyumlu bir hâle dönüşmüştür. Neriman kendisini seven gençle evlenir, Gülben görücü usulü evlenir. Safiye kendini Neriman'ın oğluna adar. Ancak Gülben'in hikâyesi iki bölüm daha devam eder. Kocası Gülben'i tesadüfen yine aynı Doktora getirir. Sorun eskilerden kalma alıskanlıktır. Gülben, annesi gibi davranır, kocasını, evi kirletecek diye neredeyse kapıda soyup eve öyle alır. Eve gelip kirletecekler diye, kimseyle irtibat kurmaz. Bir de gece cinsel ilişki sonrası hemen yıkanmalarını, kıyafetler ve çarşafların hemen değiştirilmesini istemektedir. Kocası bundan rahatsızdır. Doktor Gülben'i uyarır ancak Gülben burada kendini tedaviye kapatır, bildiğini okur. Kocası ise buna kendince bir çözüm bulur, yağmurlu bir gün her yeri çamurluyken öyleye yatağa yatar, evin her yerini kirletir ve Gülben'i sıkar, bundan sonra kendisinden izinsiz hiçbir şeyin yıkanmayacağı konusunda baskı yapar. Doktora göre bu davranış hastalı̆ı tetikleyen bir şey olması gerekirken, aksine Gülben kocasını dinlemiş, eski alışkanlıklarından vazgeçmiştir. Doktor bunu, Gülben'in ortanca çocuk olduğu için, önce anneden, sonra abladan komut almaya alışkın olmasına bağlar.

Bu öykünün temel motifi, sevmeyi bilmeyen, temizlik hastası, şiddet eğilimli, kuralcı bir annenin çocuklarına ne kadar zarar verebileceğidir. Ayrıca, çocuk anneden ne görürse onu yapar, yargısında bulunabiliriz. Sevgi, kabul görme insanın temel intiyaçlarındandır. Bunun eksikliği, hele ki ebeveyn kaynaklı ise hayatın tümünü zehredecek güce sahiptir. Safiye annesine rağmen içindeki özü kaybetmemiş, fedakârlıklar yaparak daha ilk gençliğinde kardeşlerini korumuş, hasta annesine bakmıştır. Tedaviden sonra kardeşlerine yine annelik yapmış, yeğenini bir anneanne sıcaklığında sevip koruyup kollamıştır. Neriman hem ablaları hem babası için fedakârlıktan kaçınmamış, akıllıca davranıp fedakârlığın bu durumu kurtarmaya yetmeyeceğini anlamış; profesyonel destek ile ablalarının ve kendisinin hayatını kurtarmıştır. Gülben ise gerek alışkanlık gerek soya çekim, ikisinin gücünden de, otorite saydığı eşine uyarak kurtulmuştur. Aksi hâlde temizlik- titizlik yüzünden ne sosyalleşebilecek ne de kocası ile aralarında uyum olabilecektir.

Doktor burada oldukça fedakâr bir kadın motifi olarak karşımıza çıkar. Öyküdeki kişilerin bu kadar fedakâr olduğu hikâyede Doktorun da bundan uzak olması kaçınılmazdır. Normalde muayene haricinde hasta görmeyen Doktor, iki kızı kurtarmak için kendi tatil gününü aylarca onlar için harcamıştır. Sonunda üç kızın da dostane ilişkilerine muhatap olmuştur. Burada Doktorun farklı bir yüzünü daha görürüz, Safiye Doktoru reddedip terslediğinde misliyle karşılık verir. Aksi bir hastadan kaçmaz, üstüne giderek onu çözer, hatta bazen çekilmez ve aksi olduğunu, Safiye'ye özdeşim kurmak için söylemiştir. Safiye karşısında geri çekilen birinden yardım alamayacaktır, onun yardım alacağı kişi en az kendi kadar dirençli olmalıdır. Doktor da bu davranışıyla kızları hayata kazandııır.

Çocuğun en büyük ihtiyacının anne tarafından karşılanması gereken güven olduğunu ifade eden Prof. Dr. Nevzat Tarhan, anneden sevgi ve güven alamayan çocuğun anneye karşı öfke geliştirerek suçluluk duygusu 
yaşayacağını daha sonra da iç kaygı neticesinde mutsuz bireylere dönüşeceğini vurgular (2009: 313). Bu hikâyede de özellikle Safiye'nin annesi ile ilişkisi göz önünde bulundurulursa niçin ruhsal travma yaşadığı daha net görülecektir.

Safiye, yıllarca içinde taşıdığı sırını ancak Doktora söyledikten ve anlaşıldıktan sonra hayata tutunma gücü bulmuştur. "Sır taşıyan kadın, tükenmiş bir kadındır. (...) Gördüklerinizi görün. Bunu birine söyleyin. Asla geç değildir. Yüksek sesle söyleyemeyeceğinizi hissediyorsanız, yazıya dökün. İçgüdüsel olarak güvenilir olduğuna inandığınız bir kişiyi seçin. Açılmasından kaygılandığınız solucan kutusunun, içeride irin toplayacağına, dışarıda durması daha iyidir. Tercih ederseniz, sırlarla nasıl başa çıkılacağını bilen bir terapist arayın. Bu merhametli biri olmalıdır; doğru ya da yanlış konusunda güm güm öten kendine özgü bir davulu olmayan biri, suçluluk ile pişmanlık arasındaki farkı bilen ve yas tutma ile ruhun yeniden dirilişinin doğası konusunda bilgi sahibi olan biri. (...) Bir sır açığa çıkarılmadığında, yas da her koşulda ve üstelik de ömür boyu varlığını sürdürür." (Estes, 2017: 414, 421).

2. “Cinini Çıkardım”: Bu öykü 7 bölümden oluşur. Ana karakter Rezzan adlı bir genç kızdır. Rezzan oldukça güzel, zeki, başarılı ve saygın bir mesleğe sahiptir. Ancak babası Doktora getirdiğinde bir öfke nöbeti geçirmektedir. Doktor onu sakinleştirip konuşmaya başladığında ağır bir şizofren olduğunu tespit eder. ilaç verir ancak tekrar tekrar gelmesi gerekir. Kız, çalıştığı yerdeki köylü tipteki bir adamın kendisine âşık olduğu sanrısı ile; adamın aşkı uğruna kendisini dinlediğini, her yere kamera yerleştirdiğini, evini, yatak odasını bile gözetlediğini, hatta düşüncelerini bile okuduğunu iddia eder. Adamın çok güçlü olduğunu, kendisini astıracağını ve ona yardım edenlere zarar vereceğini düşünür. Çünkü o çok suçludur, adamı da çok kızdırmıştır ve ölmeyi hak ediyordur. Esasen bunlar tamamen kızın sanrı sistemindedir. Rezzan her şeyi o adamdan bir işaret olarak algılar. Adamın, tesadüfen adamın cinini kaçırdığı için kızdığını düşünür. Adam bu öfkeyle Rezzan'ın tüm banyo ve tuvalet videolarını televizyonlarda yayımlatmıştır. Kız rezil olduğu için de artık onunla evlenemeyecektir. Adam bunu sinirinden yapmıştır ama aşkından vazgeçmez. Rezzan'ın tüm hayatı artık bu adam ve onun yaptıkları olmuştur. Korkar, üzülür, acı çeker, utanır hatta adamı sever. Hastalı̆̆ın seyri içinde Doktor kızı çözmeye çalışır, ancak başaramaz. Doktor bu sanrı sisteminin içine girmeden kıza yardım edemeyeceğini anlar ve onun gerçeklerine, onun anlayacağı dilden cevap verir. Aksi takdirde asla düzelip işe gidemeyeceğine emindir. Kıza normal davranması ve iş yaşamını tehlikeye atacak bir şeyler yaptırmamak için direktifler verir. Öncelikle ona inanan, güvenen bir profil çizer. Adamdan ve adamın yaptıklarından kimseye bahsetmemesini, işini iyi yapması gerektiğini anlatır. Sanrı sistemini daralıp zararsız hâle getirir. Kızın sorunu aslında o adamla başlamaz. Rezzan kendini günahkâr olarak görür ve bir türlü bağışlayamaz. Illk önce ortaokula matematik öğretmeninin kendisini taciz ettiğinde buna ses çıkarmayıp hoşuna gitmesi en büyük günahıdır. Sonra mastürbasyon yapması başka büyük günahıdır, adam bu yüzden ahlâksız diye onunla evlenmekten vazgeçmiştir. Doktor bunların ahlâksızlık olmadığını anlatsa da Rezzan'daki bu düşünce uzunca direnç göstermiş neredeyse cinsel organını kesip atmayı bile düşünmüştür. Hayatı boyunca başarılı, zeki itaatkâr bir genç kızın bu hâle nasıl geldiği ailesinin kodlarında gizlidir.

Doktor, Rezzan'ın annesini kliniğe çağııınca işin aslı ortaya çıkar. Kızın bu hâle dönüşmesinde etken kişi annedir. Anne de şizofrendir ve bunu kocası da bilmemektedir, Doktora geldiğinde şaşırarak öğrenir. Kocasına göre karısı Nevin aşııı titiz, düzenli, misafir sevmeyen bir kadındır o kadar. Oysa Nevin Hanım aşırı kontrolcü, kirlenme korkusu olan, temizlik takıntılı bir kadındır. Bu yüzden de ilk kızını intihara sürüklemiştir, ancak bundan kendini hiç sorumlu tutmaz. Nevin Hanım eve kimsenin gelmesini, kimsenin de zorunlu olmadıkça dışarı çıkmasını istemez, eve pislik geleceğinden korkar. Bu yüzden kimseyle görüşülmez. Her gün baştan aşağı tüm ev bir yardımcıyla birlikte temizlenir. Alınan her eşya yıkanır hatta hemen hiç eşya alınmaz. İntihar eden kız lise çağlarındadır, annesi ona da evin kurallarını uygulamak ister ancak o diretir, arkadaşlık kurar, yeni kıyafetler alır, annesi ise kıyafetleri çöpe atar, arkadaşlarına gitmesine izin vermez, üstelik kızını sık sık döver. İki kızına da hiç sevgi göstermemiştir. Ama büyük kızına 
uyumsuzluğundan ötürü hem fiziksel hem ruhsal çok şiddet uygulamıştır. Kızını, arkadaşına gitmemesi için odasına kilitlediği gün kız 8. kattan atlar ve ölür. Anne, kendisine karşı çıkıldığı için kızın cezasını bulduğunu düşünür. Yaşarken anlaşamadıklarını, çünkü kirlendiğini; öldükten sonra anlaştıklarını, öbür dünyada çok temiz ve güzel bir yeri olduğunu söyler. Ölen kızı ile irtibat kurduğunu söyleyen anne bir müddet sonra, kızının kendisini çağırdığını yazan bir not bırakarak intihar eder.

Rezzan hem genetik mirasa sahip hem de baskı kurulan bir ailede yapayalnız yaşadığı için şizofren olmuştur, ne var ki bundan kurtulmak istemez. Çünkü yıllarca hissiz yaşamış, ardından sanrı dünyasında olsa da, en coşkun duyguları tatmıştır. Kendisine duyulan aşkın her şeyden büyük olduğunu, asla bitmeyeceğini düşünür. Oysa adam başkasıyla evlenerek başka bir şehre taşınmıştır Rezzan, adamın her gece ona radyodan şarkılar gönderdiğini düşünerek uykuya dalar. Annesinin ölümünden sonra, teyzesinin kızıyla yakınlaşıp sosyal yaşama yavaş yavaş uymaya çalışsa da otoriter annenin evde kurduğu düzen devam etmektedir.

Illk öyküde olduğu gibi burada da anneden sevgi, ilgi, güven duyguları ile beslenmeyen bir çocuğun ruhsal hastalığa yakalandığı görülmektedir.

"Cinini Çıkardım" hikâyesinin beşinci bölümde, konudan bağımsız başka bir kadından, Emine'den bahsedilir. O da yalnızlıktan ve sevgisizlikten sağlığını yitirmiştir. Kocası ve çocuklarıyla Hollanda'da yaşar. Orada kocası dâhil kimseyle iletişim kurmaz. Evlerine gelen giden kimse yoktur, kocası da sessiz sakin bir adamdır. Emine üç yıl boyunca rahatsızlık belirtileri gösterir, gaipten sesler duyar ama vurup kırmaya başladıktan sonra kocası Türkiye'ye gönderir. Emine'yi getiren erkek kardeşi ablasını anlamaz. Zira eniştesi çok iyi adamdır, dövmez, sövmez 'tam bir ev erkeğidir'. Ancak bu adam karısı ile ilgilenmek yerine bolca para ile onu ailesine yollar. Doktor da kardeşin tavırları üzerine, paranın Emine'nin sağlığından bile önem verilen bir şey olduğunu düşünür.

Her iki öyküde de yalnız ve duygusuz geçirilen hayatın kişiler üzerindeki etkileri detaylandırılmıştır. Öykülerdeki kocalar, evden ve eşlerinden o kadar uzaktadırlar ki, eşlerinin psikolojik rahatsızlıklarından bile haberdar değillerdir.

3. "Binbir Gece Masalı": Bu bölüm önce bir kadın öyküsü olarak başlasa da daha sonra erkek dramına dönüşmüştür. Nihal Hanım doktorların fizyolojik sebep ve çare bulamadığı bir hastalığa sahiptir. Sürekli bayılıp düşer, ancak Nihal Hanım bu hastalıktan memnun gibidir. Çünkü hastalık sırasında eşinin ona ilgi göstermesi çok hoşuna gider. Hastalığının sebebi ilgisizliktir. Eşi ile iletişim kurma şekli budur. Eşini çok sever ama aradığı sevgiyi, ilgiyi onda bulamaz. Nihal Hanım orta hâlli bir ailenin çok güzel kızıdır. Ailesi güzelliğinin ona iyi bir kısmet getireceği düşünerek onu okula ya da çalışmaya göndermezler. Tesadüf eseri olsa bile hayalinden çok öte bir adam ile evlenir. Evlilik onun istediği gibi gitmez, bir çocukları olmasına rağmen kocası onunla hiç ilgilenmez, eve geç gelir ve geldiği gibi kendini okumaya verir. Sadece hastalandığı an kocası yetişir, başında durur. Çok şanslı zannedilen kız hiç de mutlu değildir. Kocasının ailesi, toplum onu sevse de bu ona yetmez. Doktora geldikten sonra düzelme başlar, çünkü Doktor ona sadece ilâç vermez, onu sosyal hayata katacak spor yapmak gibi başka tavsiyelerde de bulunur. Öte yandan asıl Zafer Bey'e eşinin durumunu anlatıp ona böyle davranmaması gerektiğini, ilgisizliği yüzünden eşinin hastalığını bir iletişim şekline dönüştüğünü ifade eder. Kadın Psikolojisi adlı eserde, "Çoğu zaman 'Neden kadınlar bu kadar çok hasta oluyor?' diye sorulur; ama aslında bu, bir iletişim sorunudur. Erkeklerin eşlerini hasta olduğu zaman fark edişi ve diğer zamanlarda yeterli alâkayı göstermeyişiyle ilgilidir. Kadın, sadece hasta olduğu zaman ona değer verildiğini hissettiği için, kendinde küçük bir hastalık gördüğünde, bilinç altında ona sevinir." (Tarhan, 2009: 328) ifadesi tam da Nihal Hanım'ın hastalığını tanımlamaktadır.

Doktordan kendisi için de randevu alan Zafer Bey hayatını anlatır, o da eşi kadar şanssızdır. Çok güçlü, otoriter ve sert bir babanın ezilen oğludur. Ama yine de kopmayan saygıı bir ilişkileri vardır. Annesi de 
babası da kültürlü, varlıklı, neredeyse saray eğitimi almıs soylu bir aileden gelmektedir. Ancak bunlar mutluluğa yeter şeyler değildir. Zafer Bey babasının ısrarıyla Almanya'ya gider, ihtisasını tamamlar ve üst düzeyde çalışır. Bu arada çok sevdiği bir Alman kızı vardır, baba kızı küçümser, evliliğe onay vermez. Zafer Bey evlenmeye kararlıdır, ancak Alman kız evlenseler bile rahat bırakılmayacaklarını bilir ve ayrıırlar. Bunu yenilmişlik kabul eden Zafer Bey, babasına inat uğruna, arkadaşının komşusu olan, çok güzel ama hiç tanımadığı bir kızla evlenmeye karar verir. Kızın babasının tek sorduğu şey, kızını geçindirip geçindiremeyeceğidir. Varlıklı olduklarını öğrenince hemen razı olur. Bu evlilik ne aşk ne mantık evliliğidir. Zafer Bey, babasının seçeceği bir kızla evlenmemek için tanımadığı, güzelliğini beğendiği bir kızla evlenmeyi seçmiş ama çok pişman olmuştur.

Nihal Hanım sadece güzellik sermayesine güvenir, bu ona iyi bir başlangıç yaptırsa da daha sonra kendini geliştirmez. Kocasının getirdiği kitapları okumaz, onunla ortak ilgi alanları yoktur. Kocasının ilgisini yine en basit yoldan çekmeye çalışır. Aslında sevecen ve zeki bir kadındır ama gerek ailesinin telkinleri gerekse yaşadığı sosyal çevre onu kendini geliştirmesine olanak vermemiştir. Saadetin güzellikle de parayla da olmadığının kanıtıdır.

Zafer Bey'in babası Vahit Bey hikâyenin üçüncü halkasını oluşturur. O da oğlu gibi Almanya'da bir Alman kızını sevmiş ama evlenememiştir. Mantık evliliği yapar, mutlu olamaz. Bunun aynısını oğluna uyguladığı için sonra çok pişman olup özür diler. Disiplin ve otorite konusunda sarsılmaz bir duruşu vardır. Dedeleri kadı olan Vahit Bey adalet konusunda çok titizdir. Zeki ve çalışkan oluşu ona varlık kazandırmıştır. Hem memleketlerinde hem İstanbul'da işleri yürütür. İstanbul'da dokuz katı lüks otel yaptırıp başında durur. Yetmişli yaşlarında, babası gibi, bipolar rahatsızlığına yakalanır. Oldukça mutsuzdur, her şeyden kendini suçlar ve hayatı boyunca sevgi eksikliği hissettiğini söyler. Terapi ve ilaç sonrasında düzelir ve bir müddet sonra ölür. Dördüncü bölümde hikâyeye bir kadın daha katılır. Nurhayat Hanım, İstanbullu, genç, güzel ve kültürlü bir kadındır. Vahit Beyle on sekiz yıl birlikte yaşamışlardır, Vahit Bey de ona hayat garantisi olarak, ölmeden önce isstanbul'daki oteli devretmiştir. Zafer Bey onunla görüşmek ister, o ise otelin geri isteneceği korkusunu yaşamıştır. Oysa Zafer Bey babasının hayat arkadaşını tanımak istemiş ve oldukça şaşırmıştır. Bu konuyu annesi ve kız kardeşi ile zor da olsa paylaşır. Kız kardeş tepki gösterir, aristokrat aileden gelen anne tepki göstermez ve kocasının verdiği karara saygı duyarak konuyu kapatır.

Bu hikâyede birbirinden farklı üç kadın görmekteyiz: İlki orta hâlli bir ailenin kızı, çok eğitimli olmayan Nihal Hanım onca güzelliğine rağmen; çok yakışıklı, zengin, kültürlü bir adamla evlenip sağlıklı bir oğlu olmasına rağmen mutluluğu bulamamışır. İkincisi Zafer Bey'in annesi, ataları Fatih Sultan Mehmet'e dayanan, saraylara sultanlara komşu olan, Nihal Hanım'a kıyasla çok daha şanslı gözüken bu kadın da hayatın odağında olmasına rağmen evliliğinde mutlu değildir. Vahit Bey'in kendisini on sekiz yıl boyunca aldatması ayrıca bir yıkım sebebi olsa da bunu çocuklarına bile yansıtmadan konuyu kapatmıştır. Üçüncü kadın ise Nurhayat Hanımdır. Vahit Bey'in 'hayat arkadaşım' dediği kadındır. Genç, güzel, kültürlü bir kadındır. Vahit Bey'in ailesi ile ilgili her şeyi anlattığı kişidir. Yasalar önünde hiçbir hakkı olmadığını düşünerek Vahit Bey İstanbul'daki değerli oteli ona devretmiş̧ir. O, bunun hakkı olduğunu savunur, Zafer Bey ve annesi de bunu reddetmez.

4. "Panik": Panik- atak yaşayan bir adamın hikâyesidir. Üç bölümden ibarettir. Bu hikâyede çok çalışmak ve çok sorumluluk almaktan kaçınmayan aile şirketi yöneten Yaşar Bey'in panik-atak hastalı̆̆ı söz konusudur. Etkin bir kadın varlığından söz edilmediği için bu hikâyenin üzerinde çok durmayacağız. Sadece Yaşar Bey'in fedakâr ve anlayışı eşinden bahsedebiliriz, eşine hastalığında çok yardımcı olan kadın, kocasının gözünde daha çok değer kazanmıştır. Yaşar Bey eşinin sözlerine daha çok kulak verir olmuştur. Öyküdeki diğer kadın, Doktordur. Ama bu hikâyede sadece mesleki vasfı ile öne çıkmaktadır. Eserde panik atak oluşumu, atak sırasında neler yaşandığı ve hastalığın nasıl atlatılabileceğine dair pek çok bilgi verilmektedir. 
5. "Internette Aşk Başkadır”: Jale'nin hikâyesidir. Jale çok sevdiği eşinin, bebek doğduktan sonra kendisini sevmediğini düşünerek ağır bir depresyon geçirir. Kocasının onu sevmemesi onun için ölümle eş değerdir. Jale duygusal, romantik, kıııgan yapıya sahiptir. Hayranlık duyduğu kocası, onu seçtiği için gurur duyar. Ancak çocuk bakımı ve ev işleri ile yıpranan Jale mutsuz, bakımsı ve kocasının gözünde çekiciliğini kaybeden biri hâline dönüşmüştür. Depresyon tedavisi ardından düzelip hayata dönen Jale tekrar Doktora gelir, bu kez canlı, neşelidir. Lâkin vücudu dayaktan çürümüştür, kocası ile bitmez tükenmez kavgalardan sonra şiddet gördüğü için gelmiştir. Aslında kendisi için değil, çocuğu için endişelenir. İ̧̧ hayatında kendinden küçük bir gençle arkadaşça yakınlaşan Jale kocasının kıskançlığı yüzünden bu ilişkiyi bitirmiştir. Bundan suçluluk duymaz çünkü iş yerindeki erkek arkadaşı ile yaşadığı, konuştuğu her şeyi kocasına anlatır. Hem arkadaşının hem kocasının ilgisi hoşuna gider. Arkadaşı ile iletişimi kesince Jale'ye isimsiz aşk mektupları gelir. İlkini kocasına gösterse de daha sonra gelenleri göstermez ve internette yazışmaya dayalı bir aşk yaşar. i̇kisi de evli olan bu mektup arkadaşları evliliklerinden yakınır ve dertleşirler. Adamın zoruyla buluşmaya karar verirler, ne var ki bu adam Jale'nin kocasıdır. Jale'yi o gün hastanelik edene dek dövüp sonra da onunla birlikte olmuştur, bu cinsel ilişkiden ikisi de memnundur. Ancak tekrar iletişimsiz hâle dönüştüklerinde Jale intihar eder, kocası başında bir hastanede uyanır. Jale iyileştikten sonra evde kocasına sinirden saldırır ve büyük bir kavga olur. O günden sonra Jale sürekli şiddet görmeye başlar; dayağın ardından da ikisinin de istediği gibi renkli bir cinsel hayatları olur. Jale kocasını aldatan, güvenilmez, ahlâksız kadın durumuna düştüğü için çok pişmandır, suçluluk duyguları yaşar. Kocası bu suçun cezasını olarak ona şiddet uygular; etrafa rezil olmak, yaralanmak ikisini de durdurmaz. Bu, sürekli tekrar eder, ancak Jale çocuğun bundan etkileneceğini düşünerek yardım ister. Doktor bunun için olayları Jale'ye başka bir bakış açısı ile gösterir, suçluluk duygusuyla başa çıkmak için kavga çıkarıp kocasından dayak yemeyi istediğini, buna ortam hazırladığını anlatır. Aslında tek suçlu Jale değildir. O kocasına âşıktır, kocasından ilgi ve sevildiğini göstermesini ister. Çabası hep bu yöndedir. Öte yandan karısını mektuplarla kandıran, evde hiç ilgi göstermediği için karısının başka yollara sapmasına neden olan kocanın da suçu vardır. Bunları düşündüğünde Jale tek suçlunun kendi olmadığına ikna olur. Kocasıyla kurduğu ilişkiyi sadece dayak ve sonrasında sevişme ile değil duygu alışverişi yaparak, eskisi gibi mektuplaşarak devam ettirebileceğini anlar.

Doktora göre, Jale eskiden kocasının sevgisinden şüphesi yüzünden hastalanmış, hayattan soğumuştur, dayaklar başladığından beri sevgisinden, onun için önemli olduğundan emindir bu yüzden neşesi yerindedir. Jale kocasının elinden cezasını çektiğini düşünüp rahatlar ve kocasını arzular, koca ise kendisini sanal bile olsa aldatan karısını döverek cezasını keser ve rahatlar. Böylelikle ikisi de eski tutkulu aşklarını yaşayabilmektedir.

Bu eserde dayak ve kadın tuhaf bir şekilde ilişkilendirilmiştir. Kadınlar kendilerini suçlu hissettiklerinde dayağı bir tür arınma, ceza çekme vesilesi gibi görmektedir.

Doktor bu hikâye içinde başka iki vakanın dayakla ilişkisini kurar. Anadolu'nun küçük bir köyünden gelen kadın, kocasının ilgisizliğinden yakınırken 'beni artık dövmüyor bile' diyerek sitem eder. Dayak âdeta bir iletişim şekline dönmüştür. Başka bir vakada dayak sebebiyle boşanan bir kadın, avukatı ile evlenir. Avukat, önceleri, kadını eski kocanın dövmesine hayret eder, ancak o kadınla evlendikten sonra adama hak verir, o kadının dövülmeyi nasıl hak ettiğini Doktora anlatır.

"Internette Aşk Başkadır" ve "Binbir Gece Masalı"nın kadınları tam da Freud "un söylediği şekilde evliliklerinde aradıklarını bulamadıkları için psikiyatriste gelirler. "Kadınların, evlilikte hayal kırıkığına uğradıkları zaman, hayatlarını karanlığa boğan şiddetli nevrozların pençesine düştüklerini bir kere daha söylemek isterim." (Freud, 1963: 39).

6. "Çanlar Kimin için Çalıyor?": Bu öykü çok akıllı, kültürlü, tıp öğrencisi Yiğit'in öyküsüdür. İyi ve başarılı çocuk olup büyüklerinin takdirini kazanırken; akranları arasında kabul görmez. Kabul görmek için 
yapabildiği kadar haşarılık yapar. Bu sefer akranları sever, ilgi odağı olur ama büyükleri bundan hoşlanmaz. Yiğit ikili dengeyi tutturamaz. İyi ve kötü içinde sürekli savaşır ve en son ağır bir şizofren hastası olur. Bu öykü bir erkek öyküsü olduğu için değerlendirmeye almayacağız. Öykü, şizofreni ile ilgili detaylı bilgiler içerir. Burada kadınlarla ilgili Yiğit'in fikri dikkate değerdir. O kızların kendisini sevdiğini ancak konuşabileceği derecede kültürlü, kendini geliştiren kız bulamadığından yakınır. Ona göre kızların iç dünyası çok fakir, küçük kafalı ve hayal yoksunudur.

7. "Kelebeğin Ömrü": Bu öykü diğerlerine kıyasla farklı bir çizgidedir. Burada hayattan beklediğini bulamamış, hüzünlü bir kadın hikâyesi yoktur. Bu, hâlinden memnun, onu seven bir ailede yetişmiş, hayata değer katan sevgi dolu Şule'nin hikâyesidir. Ruhsal olarak sıkıntısı olmayan Şule'nin sıkıntısı fizikseldir, ağır bir ameliyattan sonra ancak üç ay kadar yaşayacaktır. Doktorun görevi ona öleceğini söylemektir. Henüz 34 yaşında olan ve hayata dair çeşitli ümitleri olan bu kadına gerçekleri söylemek kolay değildir. Doktor da ona hayatı, mutluluğu, ölümü sorgulatan bir sohbet içine çeker ve artık keyifli bir ömür sürdüğünü anlayan Şule ölümden korkmadığını kabul eder. Burada çalışan kadının evlilik ve hayata bakışını tespit edebiliriz. Şule annesiyle yaşamaktadır hâlinden de memnundur, çünkü evlense pek çok sorumlulukları olacak ve daha çok yorulacaktır. Oysa o dışarıda çalışır, annesi ona bakar, arkadaşları ve işi ile mutlu bir şekilde hayatına devam etmektedir. Ölüm gerçeği ile birden bire karşılaşmak onu sarssa da gerçeği kabullenir.

8. "Tanrım ve Ben": Bu bölüm bir öyküden çok otobiyografik anlatıdır. Doktor bu bölümde ailesini, geçmişini anlatır ve okuyuculara düşünce dünyasının kapılarını aralar. Annesinin çocuklarına gelenek, ahlâk ve dini formları yumuşak bir geçişle kabul ettirmesi, babası ve babaannesinin buna olumlu yaklaşımına değinmiştir. Çocukken, babaannesinin yapılan her işi yazdıran, ceza veren Tanrısından korkar. Öte yandan baba-tanrı bileşimi yaparak kendi Tanrısının babası gibi merhametli, sevecen olduğuna inanır. Anne ve babasının korkutmadan, babaannesinin korkutarak yerleştirmeye çalıştı̆̆ı din algısı lise çağında yazarın ilgisini çekmiştir. Babası da ona Türkçe Kur'an hediye ederek kabul ya da ret baskısından kurtarmış, araştırmaya sevk etmiştir. Fakat o çağdaki arkadaşlarının ailesi baskı yaptığı için, arkadaşları isyanı kolay buluyorlardır. Yazar ise hâlâ bu konuları okumaya meraklıdır. Temel dini kitapların hepsini okuyup, en çok tasavvuf ve din felsefesini sevmiştir. Gülseren Budayıcıoğlu'nun kalbi; merhametli, ödüllendirici, çalışanları, mutlu olup mutlu edeni seven, haktan yana, hoşgörülü olanları, insana insanca davrananları seven bir Tanrı inancında mutmaindir.

9. "Estağfurullah": Bu öykü yine bir erkek öyküsüdür. Obsesif nevroz hastalığına tutulan bir emekli müdürün hastalığı detaylıca anlatııır. Kadına dair dikkate değer tespitler yoktur. Devlet kararı ile birden bire emekli edilen Hayri Bey inançlı olmasına rağmen içinden tanrıya küfrettiğini hissetmekte ve sürekli sesli olarak tövbe etmektedir. Bu adam oldukça titiz, kuralcıdır, devletin ve kaderin kendine biçtiği role içten içe çok öfkelenir. Duygularını bastırınca da bu hastalık meydana çıkmış olur.

10. "Suç ve Ceza": Pembe Hanım'ın öyküsü şiddet üzerinedir. Kendini, dünyaya dayak yemeye gelmiş gibi hisseder. Doğulu bir ailenin güzel kızıdır. Babası içki ve kumarla iç içedir, eve gelince karısına ve kızına odunla dayak atar. Başarılı bir genç olan Pembe tıp fakültesini kazansa da babası "orospu olmasın" diye onu okutmaz. Memleketin zengin ama 'geri zekâlı oğluna' kumar borcunun kapatılması karşııında verilir. Pembe'nin kocası aşırı kıskançtır, evde ve Pembe'nin vücudunda aldatıldığına dair bir kanıt arar, bulamasa bile Pembe dayaktan kurtulamaz. Yine de baba evine dönmeyi düşünmeyen Pembe, kocası meyhane çıkışında öldürülünce mecburen babaevine döner. Bir süre sonra babası ölür ve anne-kız kurtulduklarını düşünürler. Pembe işe girer, evlenmeyi düşünmez, erkeklerden nefret eder. Ancak toplum baskısı ile 'güzel ve dul olduğu için, adının çıkmaması için' evlenir. Yeni kocasıyla, ìstanbul'a giderler, adam Pembe'yi dul olduğu için küçümser, her şeyini eleştirir, kavga çıkarır ve sonunda yine dayak başlar. Bu sırada Pembe çalışır evi geçindirir, evle ve çocuklarla ilgilenir, kocası ise maaşını kendi keyfine harcar. íki çocuğuna da karısına da ilgi ve sevgi göstermez. Buna rağmen Pembe, düzenini bozmak istemez. Adam boşanmak ister, 
Pembe reddeder, bu yüzden hastanelik oluncaya kadar Pembe'yi döver. En sonunda kocası onu ve çocukları memlekete yollar. Pembe burada kendinden genç bir erkekle yakınlaşır. Bu yakınlaşma telefonda mesajlaşmaktan ve öpüşmekten ileri gitmez. Kendisine ilgi gösterilmesi Pembe'nin hoşuna gitmiş, kendine güvenmeye başlamıştır. Ancak telefon faturası kocasının eline geçince Pembe kocasının kendisini öldüreceğini düşünür. Adam öldürmez sadece hemen boşar. Boşasa da onu yine bırakmaz, aynı evdedirler, her gün sarhoş hâlde gelir ve karııına o adamla neler yaptığını sorar, hakaretler eder, şiddet uygular, sonra da onunla bir fahişeymiş gibi ilişkiye girer. Sonra yaptıklarından pişman olup onu çok sevdiğini söylemeye başlar. Bu döngü sürekli aynı şekilde devam eder. Ayrıca adam Pembe'ye silah getirip kendini vurması, namusunu temizlemesi konusunda da baskı yapar.

Pembe kendi ile ilgili bilgiler verirken hiçbir zaman güçlü, bilinçli, kendine güvenen bir kadın olmadığını söyler. Bu yüzden iki kocası da onu hor görüp ezmişlerdir. Hayata baba dayağı ile başlayan Pembe'nin bu hislerde olmasını Doktor tabi karşılar. Öte yandan Pembe erkeklere karşı öfke duymuş, ne yapsa sevilmemiş bir kadın olarak yaşamıştır. Namus konusunda her zaman kendine güvenip başka kadınlara kızsa da kendisi de yanılmıştır. Doktora göreyse bu bilinçdışının bir planıdır, Pembe, suçunun ölüm olduğunu bildiği bir şey yaparak adeta ölüme davetiye çıkarmıştır. Babasına, kocalarına duyduğu öfke, suçluluk duygusunu da açığa çıkarmıştır. Ancak kocası onu öldürmeyip alışkın olduğu biçimde dövüp sonra da alışkın olmadığı biçimde sevince şaşırmıştır. Doktor ona hayatının odak noktalarını gösterir ve Pembe yapması gerekenin sadece kendine güvenmekten geçtiğini anlar.

Pembe başarılı bir öğrenci olmasına, tıp fakültesini kazanmasına rağmen okutulmaz. Türkiye'de Kadın 2001 adlı eserde, kız çocuklarının "okuldan ayrııma nedenleri" arasında en büyük pay yüzde 25.2 oranı 'Ailesi göndermedi' şeklindedir. (2001: 51). Hayat gerçekliğine kurmacayla baktığımızda Pembe gibi daha nice kadının hayatının olumsuza dönüştürüldüğünü tahmin etmek zor değildir.

Mutsuz ailelerin, daha kızların küçük yaşta evlendirilmesi ve çok görücü usulü evlilik sebebiyle olduğunu görmekteyiz. Küçük yaşta evlilik kadını şiddete karşı koymakta daha güçsüz kıımaktadır, öte yandan yapılan araştırmada bu küçük gelinlerin fırsat bulduğu anda, canları sıkıldığı için, kendi çocuklarına aynı şiddeti uyguladığı ve böylelikle rahatladığı bilgisine ulaşmaktayız. (Üskül Engin, 2008: 96). İncelenen öykü ve romanlarda, iletişimsiz ailelerin evlilik şekillerinin bu tipte olduğunu görürüz. Pembe'nin evliliğinde olduğu gibi, Türk toplumunda kadının irade dışı evliliklerde temel etken başlık parası olmuştur (AbadanUnat, 1982:17). Pembe babasının borçları karşılığında evlendirilmiş ve şiddet gördüğü mutsuz bir hayata dâhil olmuştur.

11. "Ölümle Dans": Burada 17 yaşında Aslı adlı bir genç kızın hikâyesi vardır. Bu kız hayatın hiçbir çilesini görmemesine rağmen mutluluğu bilmemekte, hiçbir şeye kanaat etmemekte ve her şeyin en mükemmelinin peşindedir. Bu yüzden hayattan nefret eder, intihar etmek düşüncesindedir. Doktora karşı da öfke içindedir, hatta sırf Doktoru başarısız kılmak için intihara meyleder. Doktorsa bunların farkındadır, ona kendi gerçeklerinden ve etrafındaki dünyanın haricinde dünyaların var olduğunu anlatarak genç kızı ölümün eşiğinden alır.

12. "Aç Milyarder": Öyküde kadına dair bilgi yoktur, Karadenizli bir işçi olan Mustafa'ya lotodan büyük ikramiye çıkmıştır, bu yüzden günlerdir şoktadır, yemez, içmez ve uyumaz. Doktor bir şeyler yedirip içirerek hastayı kendine getirir ancak o, ne yapacağını hâlâ bilemez. Doktordan tavsiye alarak gider. Burada konuyla ilgili sadece şunu söyleyebiliriz, Mustafa Doktora 'Doktor Bey' diye hitap eder; yazar, neden hanım değil de bey dediğini sorunca 'Bizim oralarda öyle derler' diyerek cevap verir. Bir cümle ile de olsa kadına bakış açısını görebiliriz.

13. "Tahtını Çaldıran Adam”: Bu öykü oldukça sert görünümlü, hissiz denebilecek kadar sert, 41 yaşındaki gazino yöneticisi Garip Bey'in hikâyesidir. Ancak kadın onun öyküsünde belirleyici olduğu için inceleyeceğiz. Garip Bey, yıllarca gazinoda değişik kadınlarla iş yapmış ama hiçbiri ile ilişkisi olmamıştır. 
Garip evli, 21 ve 20 yaşında çocukları olan bir adamdır. Karısı ile hemen hiç konuşmaz, sadece evin parasal intiyacını giderir. 19 yaşında gazinoya gelen tecrübesiz bir kız Garip'i âşık etmiştir. Garip'in yıllardır sevgilisi ile el ele tutuşup gezme isteği bu kızla gerçek olmuştur. Genç, güzel ve temiz olan bu kızı Garip korumak ister. Kızın isteği evlenmek, anne olmak ve namuslu yaşamaktır. Ancak Garip onu kandırmadığını, gerçekleri söylediğini, ona ömür boyu bakacağını ve onu seveceğini söylemiştir. Bu hâlde iki ay aşk yaşayan Garip, kızın genç ve zengin bir adamla gitmesine öfke duyar. Kandırıldı̆ını, hiç sevilmediğini düşünür, onu öldürmek ister; bu kararında da ısrarcıdır. Doktor onun bu öfkesinin derinlerde olduğunu anlar. Garip annesi, babası ve karısı tarafından hiç sevilmemiştir, en sonunda kendi de kendini sevmemiştir. Doktor Garip'e yardım etmeye çalışırken 19 yaşındaki kızı da ölümden kurtarır.

Bu kız kimsesizdir, gazinoya düşerek zaten kaderi çizilmiştir. Babası yaşında, evli bir adamla aşk yaşamıştır, ölüm tehlikesini göze alarak hiç tanımadığı başka bir adamla gitmiştir. Ayrıca ona âşık olan adam; kızın, kendisiyle birlikteyken temiz; başkasıyla gidince fahişe olduğunu söyler. Ayrıca bu adamın âşık olduğu kadına kestiği ceza ölümdür. Ne kadar saf temiz olsa da ya yaşlı ve evli bir adamın kapatması olacak ya da öldürülecektir. Hikâye, gazinoya adım atan kızların hayatına erkek gözüyle içerden bir bakış olarak ilginçtir.

14. "Sapık mıyım Ben?": Dünyaya kadın bedeninde gelip, çocukluğundan beri erkek gibi hisseden bir genci ele alır. Halime ya da Halim'in hikâyesi oldukça dramatiktir. Orta Anadolu'nun bir köyünde oğlan çocuk isteyen ailenin üçüncü kızıdır. Anne dördüncü doğumda ölünce 3 yaşındaki Halime, evlatlık arayan varlıklı bir aileye para karşılığı verilir. Üvey annesinden memnun olan çocuk üvey babasından nefret eder. Baba yaşılır, dindar görünür, çocuğu sürekli döver ve tesettüre sokar. Anne evden uzaklaştığında üvey baba, kızı daha çok döver ve döverken taciz eder. Kız evde yalnız kalmak istemez ama üvey teyze, mirasın kendi kızına kalması için üvey anneyi Halime’ye karşı kışkırtır ve kızla babanın evde yalnız kalmasını ister. 14- 15 yaşlarındayken yine dayak ve tacize kalkışan adamı duvara savuran Halime'yi evden kovarlar. Öz babasına para verip mahkemede yalancı şahit olarak kullanırlar ve evlatlıktan reddederler. Bu sırada babaevindeki üvey anne Halime'yi istemez. Dayısına gider, orada da yenge istemez. Nihayet liseyi bitirinceye kadar bir yurtta kalan Halime verem olur ve istanbul'da birkaç sanatoryum gezerek tedavi olur. Ne var ki sanatoryumda kızlarla yakınlaşan Halime eşcinselliğini keşfeder. Okulu bitince başka bir okula memur olur. Erkeklerden hep nefret eden Halime kızlardan hoşlanır, cinsiyetini reddeder. Çalışı̆̆ı yerdeki bir erkek ile hem kendini denemek hem de toplumsal baskıdan kurtulmak için evlenir ancak kocasının kendine dokunmasından tiksinir. Okulda bir öğretmenin de kendisi gibi olduğunu görür ve birbirlerinden cesaret alırlar. Öğretmen sevgilisi ile aynı evde yaşamaktadır, herkes onları iki kız arkadaş gibi görse de onlar sevgilidir. Öğretmen de Halim de devlet memuru oldukları için işten atılma korkusu da yaşarlar ancak öğretmen üniversite hastanesine, Halim de özel psikiyatra başvuru yaparak cinsiyetlerini değiştirmeye karar vermişlerdir. Doktor bu bölümde homoseksüellik ile transeksüellik hakkında bilgi verir. Halim'in hayatını dinledikten sonra, erkeklere olan nefreti yüzünden onlardan uzaklaşıp güçlü erkek formuna girmek için mi, yoksa yapısal bozukluk nedeniyle mi dönüşmek istediğini anlamak ister. Yapısal sorun gibi gözükse de Halim'in durumunu incelemek için süre ister.

15. "Kırık Hayatlar": Bu bölüm birbirinden bağımsız iki hikâyeden oluşur. Ilki Doktorun yürürken sokak ortasında bir gence baba ve amcası tarafından yapılan baskı ve atılan tokadı eleştiren konuşmasını hikâye eder. Bu bölüm bağımsız bir prolog gibidir. İinci ve asıl hikâye ise, Reyhan Hanım'ın kimseye yaranamadığı hayatını konu edinir. Reyhan Hanım ailesinin ortanca kızıdır. Ailesini sever ancak ablasının ve erkek kardeşinin gölgesinde kalmış, istediğince göz önünde olamamış sevilememiş bir çocukluk ve gençlik geçirmiştir. Evlenir, kocasını sever; kendine göre dört dörtlük bir kadındır, temiz, titiz, becerikli iyi bir anne, kocasıyla ilgilidir. Ancak buna rağmen kocası ona ilgi göstermez, eve geç gelir, gelince de karısını umursamaz hatta küçümser. Âdeta adam efendi, kadın köle gibidir. Öte yandan kayınvalidesi ile iyi geçinir, annesiyle en çok o ilgilenir yine de 'kimseye yaranamaz'. Doktor Reyhan Hanım'a anlattıklarından yola çıkarak; sürekli sevgi, şefkat aradığını, onay beklediğini, kendine güvenmediğini göstermiştir. Yıllardır 
'yaranmaya çalışan' rolünü Doktorun sayesinde, zor da olsa bırakan Reyhan Hanım aradığı mutluluğu bulmuştur.

16. "Kader Kurbanları": Bu bölüm hayat kadınlarından bahseder. Doktor, hamile hâli ile dövüp hastanelik ettikleri Elmas'ı hayata döndürmüştür. Elmas artık genelevden kurtulmuştur. Elmas, bu kez de yanında çalışan başka bir fahişeyi Doktora yollamıştır. Hayal Doktora çok öfkeli davranır, aşağılanmaktan kendini korumak ister, ne var ki, Doktorun deyimiyle, onlar davranışları ile önce kendi kendilerini aşağılamaktadır. Hayal, Doktora uyuşturucu niyetine aldığı ilacı yazdırmak için gelmiştir; ama Doktor onu dinlemek ister. Hayal, hâkim bir baba ve öğretmen bir annenin kızıdır. Bir de kız kardeşi vardır. Genç kızken okumaya niyeti yoktur. Babası onu sık sık döver, ama o kendini babasına ezdirdiği için annesine daha çok kızar. Lise bitmeden âşık olduğunu söyleyerek, anne babası karşı çıksa da, işsiz bir gençle evlenir. Yıl dolmadan geri döner ve boşanırlar. Baba baskısı bu kez daha da artar, ilk kocası gibi işsiz birine daha âşık olan Hayal bu kez onunla istanbul'a kaçar. Paraları bitince kaçtığı adam Hayal'i satmaya başlar, bir süre sonra da geneleve satar. Birkaç yıl içinde fiziksel ve ruhsal olarak çöken Hayal ilaç kullanmaya başlar. Hayal doktorlara gitmeye başlayınca onlardan bile iğrenir çünkü kadın doktorlar aşağılar, erkekler ya başından savar ya da ilişki kurmak ister. Sadece doktorlara değil toplumun dışlanmışlığından yakınır. Öte yandan kendi meslektaşlarını da eleştirir: 'Kimse istemese bu yola düşmez' der. Kendinden iğrenir, erkeklere olan ilgisi yüzünden başına bunların geldiğini düşünür, suçluluk hislerini azaltmak için kendini erkeklere dövdürür ve sürekli uyuşturucu ilaçlar kullanır. Ölümün ya dayak ya uyuşturucu ile geleceğini bile bile bu hayata devam eder. Bu bölümde Doktorun ilk defa bir fahişe ile karşılaşması ve ona insanca davranması anı olarak yer alır. O kadın herkesin itiş kakışı içinde hastanenin ortasına tuvaletini yapmaya kalkınca Doktor onu korumak ister; ancak fahişe iyileşip giderken, Doktora, kendi gibilere insanca muamele yapmaması konusunda uyarır. Çünkü insan olmaya alışırken taburcu olur, Doktor 'ona insan muamelesi yaparak yarasını kanatmış'tır.

"Biraz da Beni Tanımak ìster misiniz?": Bu bölüm, yazarın kendisi, annesi ve meslekî başarıları ile ilgili olan anılarından ibarettir. Kitapları arasında kendi hayatı ve düşüncelerine en çok burada yer ayırmıştır. Bu bölüm öykü olmasa da, edebi bir tür olan anıyı, burada kadın ve yazar kimliği açısından incelemeye dâhil etmeyi uygun görüyoruz.

Yazar anne ve babasından başlar, ikisi de Çorum-iskiliplidir. Babası memur olunca, sokakta oynarken gördüğü Nezahat'le evlenmek ister ve yazarın annesi Nezahat 15 yaşında Ankara'ya gelin gider. İki yıl çocukları olmaz, ilk çocuğuna hamileyken, kadın bir jinekolog gebelik şişliğini ur zannederek almak ister. Ancak bir müddet sonra yazar doğar. İlk çocuk olmanın şansları yaşayan yazar, bir kız, bir erkek kardeşi ile sevgi dolu, saygılı ve güvenli bir ortamda büyütülmüşlerdir. Yazar için baba hem otorite hem güvenin, anne ise merhamet ve kendine güvenin sembolüdür. Annesi ona vazgeçmemeyi ve daima elinden gelenin en iyisini yapmayı öğretmiştir. Ankara Tıp Fakültesi ikinci sınıftayken TRT'nin spikerlik başvurusuna alınır ve sınav sonrası eğitimle TRT'de spikerlik yapmaya başlar. Koşullarının çok zor olduğunu ama ikisini de severek yaptığını ifade eder. Gazetecilerin o yıllarda hakkındaki yalan haberden dolayı, TRT genel müdürünün kendisine sahip çıkışını hatta tazminat kazandığını anlatır. Çok sevdiği eşi ile evliliklerine değinir. Bir anı olarak, 'hep güçlü görün'düğü için hâlinin sorulmadığını ancak babasının kanseri ile mücadeledeyken çok yorulduğunu itiraf eder. Bu yorgunluğunu, ona hasta olarak gelen yaşlı, okuma yazması olmayan, Yozgatlı bir teyzenin fark ettiğini anlatır. Bu teyze ona iyi bir ruh doktorunun nasıl olması gerektiğini, sevgi dolu yüreğiyle öğretmiştir.

Yazar en son olarak kocası, çocukları ve torunu ile olan sevgi ve güvene dayalı ilişkilerinden ardında da işini nasıl sevip ciddiye aldığından bahsetmiştir. Yazarın hayatının ve işinin özünde daima sevgi ve hoşgörünün olduğunu çok net bir şekilde söyleyebiliriz. 
Bu eserdeki kadın tiplerini toparlarsak, genelinin sevgi ve ilgiye aç olduğunu görürüz. Bir kısmının şiddete maruz kaldığını, bunu da içlerindeki suçluluk duyguları ile yapanlar ve daha doğuştan şanssız olup dayakla tanışanlar olarak ikiye ayırabiliriz. Ayrıca ruhsal darbelerin en çok anne, baba ve kocadan kaynaklı olduğunu görmekteyiz. Özelikle annenin çocuklarda açıı̆ı yaralar kapanmayacak izler bırakmaktadır. Kadınların rahatsızlarını dışarıya en çok yansıttıkları gösterge de aşırı temizlik olarak dikkat çeker. Bir diğer husus, kadınlar daha ailede aşağılanmaya başladılarsa kendilerini değerli hissetmeyi bilmeyip ve eşlerinin de benzer tavırlar sergilemelerini normal karşılamalarıdır. Başka bir konu, kadının ekonomik özgürlüğüdür, bazı hikâyelerde kadın ekonomik özgürlüğe kavuşsa da zihnindeki prangalardan kurtulamamaktadır, çünkü bu zincir ona çocukken takılmıştır. Spesifik olarak cinsiyet değiştirme, ölümle genç yaşta karşılaşma gibi vakalarda Doktor yine hastayı anlamayı, gerekirse ona en net açıklamayı yapmayı doğru bulur. Hayatın en dışına itilmiş hayat kadınlarına olan tutumu ise onları bile şaşırtır. Kendi hayatlarına ve kimliklerine değer biçmeyen bu kadınlar Doktordan gördükleri ilgi ve anlayışa şaşııılar. Doktor hastalarını konuşturup kendi gerçeklerine yine kendilerini şahit tutmuştur. Doktor bunu yaparken en çok soru cevap şeklini kullanır ve cevabı hastaların kendisi bulur. Öte yandan suçluluk duygusu ile başa çıkmaları için de tek suçlunun kendileri olmadığını, hatta suç saydıkları şeylerin bazen bir zandan ibaret olduğunu gösterir. Bu bakımdan "kadını güçlendirmeyi değil kadına güçlü olmayı" öğretir.

\subsection{Günahın Üç Rengi ${ }^{4}$}

Öykülerden oluşan eserde beş ayrı bölüm gözükse de aslında birbirleriyle ilintili hayatları anlatan üç temel öyküden ibarettir. "Fahişeliğin Rengi Kırmızı" başıklı ilk öykü tümüyle kadını anlatır. Kadın olmanın talihsizliğini, acıyı, aşkı, cinsel zorbalığı esas alır. İkinci öykü "Eşcinselliğin Gri Rengi” adını taşır, eşcinsellik ve temellerini konu edinir. Bir erkek dramını içerir. "Mazoşizmin Rengi Siyah 1-2-3" başıklarını taşıyan üçüncü öykü ise kadının erkekte yarattığı travmayı, mazoşizmin nasıl temellendiğini ele alır. "Günahın Üç Rengi" adlı dördüncü öykü ise ilkiyle bire bir bağlıdır. Çünkü ilk vakada anne, bu vakadaki kızın annesidir. Anne, kızının geleceğinden, kötü yola düşeceğinden çok korkmasına rağmen buna engel olmaya gücü yetmez. Beşinci öykü "Umuda Doğru” adını taşır. Dördüncü bölümle ilgilidir. Aynı zamanda diğer kişilerin de akıbetleri ile ilgili bilgilerin aktarıldığı bölümdür.

“Fahişeliğin Rengi Kırmızı": Öykünün ana kişisi Meliha Kınık'ı́r. Olaylar bu kadın etrafında döner. Meliha orta yaşı geçmiş bir kadındır. Kara kaşlı, kara gözlü, beyaz tenli güzel bir kadındır. Hafızdır, evlere mevlit okumaya gider. Dirayetli, güçlü bir kadın olarak gözükür. Kızı, intihar etmek üzereyken annesini görür ve Doktora getirir. Meliha bir sır küpüdür. Hayattan umudunu kesmiştir. Başına türlü şeyler gelmiştir. 10-12 yaşlarındayken babası gözlerinin önünde kurşunlanıp öldürülmüştür. Ardından annesine pek çok erkek tecavüz etmiş ve anneyi ölünceye kadar bu yolda kullanmışlardır. Bu sırada 15-16 yaşındaki ablayı kaçırıp tecavüz etmişlerdir. Jandarmalar kızı bulup getirse de annesi ölünce köylüler bu kızı da aynısını yapma devam etmişlerdir. Birkaç yıl sonra 6 kardeş yürüyerek köyden Ankara'ya kaçarlar. Abla kardeşleri için kendini Ankara genelevine satar. Kardeşlerine uzak bir muhitte ev tutar, onlara namuslu yaşamalarını öğütler, para gönderir, bir müddet sonra da bıçaklanarak öldürülür. Bu sırada erkek kardeşler marangoz, kızlar terzi yanında çıraklık yapmaya başlamışır. En büyük olarak Meliha evin idaresini eline almış, kardeşlerini koruyup kollamıştır. Kardeşlerini evlendirdikten sonra, istememesine rağmen, tek başına yaşamanın zorluğunu bildiği için, evliliği toplum baskısı ile yapmıştır. 26 yaşındayken, 45 yaşındaki dul ev sahipleri ile evlenmiştir. Ancak kocası çok kıskanç ve dayakçı bir adama dönüşmüştür. Ölen ilk eşine böyle davranmamasına rağmen genç ve güzel olduğu için Meliha'ya kıskançıktan göz açtırmaz, kapı dışına çıkarmaz. Kendisiyle para için evlendiğini, gözünün gençlerde olduğunu düşünür, kendi oğlundan bile kıskanıp hastanelik edinceye kadar döver. Meliha'yı soyup vücudunda morluk kızarıklık arar, banyoya

\footnotetext{
${ }^{4}$ ilk baskısı 2007 yılında yapılmışır.
} 
götürür ıslatıp öyle döver. Ancak Meliha'nın evlenmeye niyeti olmadığı gibi boşanmaya da niyeti yoktur. íki kızları olmuştur. Kocasının tüm ihtiyaçlarını giderir ancak ne kendi ne kocası mutludur. Meliha'nın en büyük korkusu annesinin kaderini yaşamak ve toplum tarafından dışlanmaktır. Bu yüzden kendini, kız kardeşlerini ve kızlarını erkeklerden korumaya çalışır. Annesini anlatırken, 'çok güzel, çok oynak bir kadındı der. Hatta bu özelliğinin hayatını mahvettiğini düşünür. Kız kardeşleri ve kendisi annelerine çekmediği için şanslıdır ancak büyük kızı Melek onu korkutur. Çünkü annesi gibi çok güzel ve oynaktır. Aklı fikri süslenmektedir, eline aldığı her işi başarır ama aynı zamanda çok da dikbaşlıdır. Bu yüzden annesi onu çok sıkar, aşırı disiplinle büyütür ki 'güzelliği başa bela' olmasın. Kıskanç bir babanın yanı sıra anne baskısı ile kızını bunaltır. Süslenmesine, toka takmasına bile müsaade etmez. Ancak bu baskıyı küçük kızına yapmaz çünkü o mülâyimdir. Meliha'yı Doktora getiren de bu kızıdır. Büyük kız Melek 16 yaşlarındayken apartmanda çıkan bir yangında kaybolur. Meliha yangının içinde defalarca onu arasa da bulamaz, cesetler de tanınmayacak hâlde olduğu için teşhis edilmeden öldü kaydına geçilir.

Meliha'nın üvey oğlu Necdet, babası Meliha'yı döverken elinden kurtarır. O babasına karşı gelmeyen sakin bir gençtir. Meliha ile babası evlendiğinde 17 yaşındadır. Okulu, askerliği bittikten sonra, babasının zoruyla evlendirilir ve babasıyla çalışmaya başlar. Ancak ekonomik kriz yüzünden malî zorluğa düşerler, Necdet'in kefilliği ile evlerine haciz gelince baba Necdet'i döver ve iletişimini keser. Malî sıkıntı ile Meliha evlere mevlit okumaya gider. Bu sırada Necdet kanser olur ama babası ilgilenmez. Necdet'in karısı çocuğu da alıp onu terk eder. Necdet'e acıyan Meliha mevlitlerden sonra ya da önce ona bakmaya başlar. ilaçları, yemekleri derken ölümcül hasta toparlanır ve Necdet ilk günden beri Meliha'ya âşık olduğunu itiraf eder. Meliha bundan kaçmak istese de başaramaz. 'Zaten ölmek üzere ve benden kalbimden başka bir şey istemiyor, bu masum bir aşk' diyerek o da Necdet'e âşık olur. Bunu filmlerdeki temiz aşklara benzetir. 'Eli elime değmedi' der. Sadece konuşarak hayal kurarak bir aşkı büyütmüşlerdir. Ne var ki ölmek üzere olan hasta aşkla hayata tutunmuştur. Fakat bir gün ansızın Necdet'in evine giden Meliha, Necdet'in yatağında bir kadın görür ve travma geçirir. Eve döner evdeki tüm eşyalarını konu komşuya dağıtır, Necdet'in dokunduğu saçlarını kazııır, abdest alıp intihar ipini hazırlar, yakalansa da intihardan vazgeçmeye niyeti yoktur. Kafasına koyduğunu yapacağını ifade eder. Hayatta çekmediği derdin kalmadığını, bu sonuncusu ile çok günahkâr olduğunu, çok kızdığı annesine benzediğini düşünerek Allah'tan af diler. Meliha çocukluğunda geçirdiği ilk travmanın etkisini ömrü boyunca içinde yaşatmıştır. $O$ anı her ayrıntısı ile hatırlar, Doktora gelinceye dek kimseye derdini anlatmamıştır. Ablasının kendini onlar için feda etmesi yükünü artırmışır. Evlendiği adamın kendini paragöz ya da iffetsiz zannetmesi hayatını çileye dönüştürmüş, dahası evli olduğu adamın oğluna da 'platonik' de olsa âşık olunca kendini affetmeyi bir türlü başaramamıştır. Ancak Doktora gelince tüm sırlarını anlatır yüklerini boşaltır, sonunda intihar düşüncesinden vazgeçer.

Öyküdeki anne, Meliha tarafından hem övülür hem yerilir. Anne güzel, alımlı ve 'oynak' bir kadındır, bu tip kadına köyde iyi bakılmamaktadır. Çok daha iyi bir evlilik yapabileceği hâlde, oynaklığı yüzünden oduncu ile evlenip köyün dışında bir evde yaşar. Art arda altı çocuk doğurmuştur. Kocasına âşıktır, kocasına da ona, hatta çocukları bile gözü görmez. Kocasıyla beraber ormana odun toplamaya gider. Çocuklar birbirlerine sahip çıkar. Tecavüz olayından sonra 'az olan aklını tümüyle yitirmiş gibi'dir. Bazen içli içli ağlar, bazen tüm adamlar gittikten sonra türkü tutturur. Radyoda neşeli şarkı çıksa göbek atarak oynar. Ancak birkaç yıl içinde solup aylarca yatalak kalır ve ölür.

Abla anne rolündedir. Çocukları koruyup kollar. Akılı ve beceriklidir. Çocukları besler, temizler ve onları bu bataktan kurtarmak için köyden kaçarlar. Kendini satma pahasına kardeşlerine temiz bir hayat kurar. Kaderin batağa çektiği kadınlardan biri olarak, çocuk yaşta kaçırılmış, tecavüze uğramış, geneleve kendini satmış ve genç yaşında bir adam tarafından bıçaklanıp öldürülmüştür.

Meliha anne ve ablasını çok sever ancak o günlerin acısı içinde hep tazedir. Ebeveynlerinin ölümü, tecavüz, dayak, açık, sürgün, toplum tarafından dışlanmışlık gibi pek çok ağır durumu daha çocuk yaşta 
yaşamıştır. İlk gençliği hatta tüm hayatı bu acıları tekrar yaşama korkusu ile geçmiştir. Sonrasında dayakla geçen bir evlilik ve kızının ölümü ile acıları katlanır. Meliha, anne ve ablasını düşündükçe erkeklerden nefret eder. Kardeşlerinden başka kimseyi sevmeyeceğini düşünse de üvey oğluna acıyarak bakması onun felâketi olur.

"Eşcinselliğin Rengi Gri” başığını taşıyan ikinci bölümde yazar önce kendi geçmişinden, çocukluğundan, ailesinden sonra da yirmi yıllık hastası İsmail'den bahseder. İsmail'in en büyük arzusu, emekli olup kimseye muhtaç olmadan ve Doktora herkes gibi ücretini ödeyerek gelebilmektir. Bu hikâyede belirgin bir kadın motifi yoktur. İsmail'i hastalandığında ablaları getirmişlerdir, annesi ile gecekonduda yaşar. Anne ile görev ilişkisine dayanan bir ilişkileri vardır. Bu bölüm esasen Şevket Yıldırım yani 'Şevket Ağa' hikâyesinin başladığı bölümdür. Burada kadın etkisini ciddi bir şekilde görürüz. Şevket Ağa kadınlardan korkan, kaçan bir adamdır. Oldukça varlıkı ve nüfuzlu bir adam olmasına rağmen, kadınların yanında çok utanır, gerilir. Yanında kadın çalışan bile yoktur. Kadın doktora da arkadaşının zoruyla getirilmiştir. Doktoru oldukça zorlamıştır. Konuşmakta açılmakta direnmiştir. Onun esas hikâyesi cinsel bunalımıdır. Evli ve dört kız babasıdır, karısı ve kızları memlekettedir. Ankara'da yıllardır yalnız yaşamaktadır. En büyük sorunu, içi daraldığında kılık değiştirerek, yaşlı kasketli kötü kokan, kirli ama kendine yakın hissettiği bir adamı sokakta bulup onunla bir otel odasında sarmaş dolaş yatmaktır. Bunu yaparken birçok tehlikeyi göze alır, ruhundaki gerilim bunu yapmadan dinmez. Tüm kadınlardan kaçan, istediği tipteki erkeklerle cinsel birleşim olmadan onları otelde bırakıp kaçan bu adam utançla yaşamaktadır. Sokakta bulduğu adamlarla da ikinci kez karşılaşmamak için çok çabalar. Doktorla uzun terapiler sonucunda bu davranışının altından, çocukluğunda babasından aynı davranışları görmesi çıkar. İnşaatta çalışan baba ile oğul şehirde yalnız yaşarlar. Baba otoriter ve kolay beğenmeyen bir adamdır. Çocuk Şevket hem okula gider, hem babasıyla inşaat işlerinde çalışır. Kendini babasına beğendirmek için derslere ve inşaat işlerinde gayret gösterir. Babası ile bir yatakta yatarlar baba, oğlunu takdir ettiği gecelerde onu taciz eden okşamalar yapar ve bu yıllarca sürer. Ancak Şevket bunun taciz olduğunu Doktora geldiğinde anlar. Yıllarca, babasına benzeyen adamlardan da takdir sonrası beklentiyle, babası gibi yapmaları için peşine düşer. Aslında aradığı cinsel haz değildir. Babasının tek onaylama belirtisi olan sarılmalar ve okşamaları yaşamak ister. Bunu anladıktan sonra bir daha baba tipindeki adamlarla tehlikeli ilişkiler yaşamaz.

Babası o lisedeyken ölür. O da babasından kalan işleri büyüterek oldukça zenginleşir ama kimseden takdir, övgü göremez. Aradığı onaylanmaktır. Şevket Ağa'nın hayatındaki kadınlar da onun bu hâle gelmesine sebep olmuştur. Öncelikle annesi oğluna ve diğer çocuklarına sevgi ve ilgi göstermemiştir. Hatta baba, anneye fazla fazla para gönderse de o bu parayı biriktirmiş, çocuklarının bakımına bile harcamamıştır. Anne, sevgiden yoksun bir kadındır. Şevket Ağa'nın usulen evlendirildiği kadın da anne profiline çok benzer. Yıllardır Ankara'da yaşamasına rağmen eşi ile yılda birkaç kez görüşür. Ankara'dan memlekete her gittiğinde karısı hamile kalmıştır dört kızı vardır, sonra da başka bir ilişkileri olmamıştır. Karısı kendinden büyüktür, becerikli, çok çalışkan ve çirkin bir kadındır, onca varlık içinde ne giyinip süslenmiş, ne işlerini başkasına yaptırmıştır. Fazla para istemez, nasıl harcayacağını da bilmez. Şevket Ağa, karısı hakkında bu bilgileri verir 'yine de namusludur, iyi insandır, gözüm arkada kalmaz' der. Bu bilgiler arasında dört kızı ve beş kız kardeşi ile ilgili hiçbir bilgiye rastlanmaz. Anne ve eşinden yakınan Şevket Ağa'ya kızların ya da kardeşlerinin de yakınlık göstermemeleri dikkat çeker.

Şevket Ağa'nın şu sözleri, düşüncesinin özünü vermesi bakımından önemlidir: "Karıları oldum olası sevmem. Ömrüm boyunca bana yakın olan hiçbir kadın olmadı. Anam köydeydi, ben kasabada. Şimdi de karım memlekette, ben buradayım. i̇kisinin de yüzü gülmez. Yanlarında olmadığıma bir yiyip bin şükrediyorum. (...) Elimden gelse dünyadaki bütün kadınları başka bir gezegene göndereceğim." (Budayıcıŏlu, 2017b: 82, 84).

Şevket Ağa'nın kadınlardan korkması ise başka bir olaya dayanır. Kadınlardan uzak duran, güçlü ve otoriter olan bu adam, çok samimi bir arkadaşının karısı tarafından çağrıldığını bilmeden, bir otel odasına gider. 
Ancak gördüğü kadın karşısında şok geçirir. Zira kadın, güçlü bir aşiretin gelinidir ve kocası Şevket'in en samimi dostudur. Ne yapacağını bilemez, bu sırada kadın odayı terk etmez. Şevket Ağa'nın başı döner ayağa kalkamaz kadının ağır parfümü yüzünden iyice daralır ve otelden kaçarak hastaneye gider. Alerjik kriz teşhisiyle yatırılır. O günden sonra, zaten evvelden de sevmediği, kadınlardan nefret eder. Bir daha hiçbir arkadaşının evine gitmez, tüm kadın çalışanları işten çıkarır. Bir kadınla sadece konuşurken bile gerilir. Ancak Doktorla görüşmelerinden sonra hem tuhaf erkek ilişkilerinden kurtulur hem de kadınlarla olan tutukluğu açilır.

Bu hikâyede kadın payı iki şekilde karşımıza çıkar. Biri sevgiyi tanımayan, bilmeyen ve sevgi göstermekten de yoksun olan kadın tipi: Şevket'in annesi ve karısı bu şekildedir. Annesine karşı Şevket de sevgi beslemez, hatta eleştirir. Karısına karşı ise sadece saygı besler. Zaten ona göre karısı, memlekette aranan nitelikte bir kadındır. 'Bizim oralarda eve gelin değil, hizmetçi alınır.' (Budayıcıŏlu, 2017b: 93) sözü bile kadını değerlendirdiği kıstası ortaya koyar. Bu kadınların, neredeyse, iş yapmaktan, büyüklerine hizmet etmekten başka vasıfları yoktur. Sevgi, hayatın içinde görülerek, bilinerek öğrenilir. Bu tip kadınlar belki de kendileri sevilmedikleri için sevmeyi de bilmemektedirler.

Diğer kadın profili ise, zevk uğruna kendini, çocuğunu bile ateşe atan fettan kadındır. Kocasının en yakın arkadaşını otelde ayartmaya çalışan bu kadın yüzünden Şevket Ağa kadınlardan iyice tiksinmiş ve kaçmaya başlamıştır.

Üçüncü hikâyede kadınların yaraladığı bir gencin hikâyesi anlatılmaktadır. Burada yaralanma hem ruhen hem de bedenen karşımıza çıkacaktır.

"Mazoşizmin Rengi Siyah 1-2-3": Salih Ersan otuzlu yaşlarda, yakışıklı ama ürkek; varlıklı, görgülü bir aileden gelmektedir. Oldukça çekingen davranarak Doktoru zorlar. Açıldığında ise onun hayatını yönetenlerin kadınlar olduğu anlaşılır. Hayatındaki acılar daha o doğmadan önce başlamıştır. Babası ve bir ağabeyi, Salih'in doğumuna birkaç ay kala, kazada ölmüşlerdir. Salih beş yaşındayken de diğer Ağabeyi şofben zehirlenmesi ile ölür. Zekâ özürlü olan ablası da Salih lise çağlarındayken ölür. Anne, hamileliğini anladığında, üç büyük çocuğu olduğu için Salih'i doğurmak istememiştir. İstenmeyen bebek olduğunu Salih bilir. Annenin ölüm acısına bebek Salih merhem olamamış, her seferinde 'olmaz olasıca' sözü ile azarlanmıştır. Etrafında anne, teyze, abla gibi kadınlarla büyüyen ama hiç sevgi görmeyen, küçükken oyuncaklara, büyüyünce dersine gönderilen Salih hiçbir zaman adam yerine konmamışır. Öte yandan kaybetme korkusu yüzünden Salih'e daima çok titiz bakılmıştır. Ama bu bakım sevgi ve onaylamayı beraberinde getirmez. Annesiyle beraber yatmasına rağmen sıcaklık görmez, gece altını ıslanan çocuğa anne merhametsiz davranır. Salih büyümeye başlayınca yine kadın ortamında ama dışlanmış şekildedir. Ergenlikle birlikte kirlenmiş çarşafları gören anne oğlundan tiksinir ve bu Salih'i de kendinden tiksindirir. Zira annesi, teyzeleri özellikle ablası yanında yarı çıplak dolaşırlar ve rüyasına gelen akrabaları Salih'i utandırır. Annesinin de bunu anladığını düşünür. Ablasını uygunsuz olarak gördüğü rüyanın sabahında ablası ölür. Salih bu ölümden kendini ve gece rüyalarını sorumlu tutar. Nasıl olduğunu bilmeden, git gide kadınlardan etkilenmemeye başlar. Ne var ki üniversite sonrası istemese de ailesi onu evlendirmek ister. Dinen çok mutaassıp olan aile, görücü usulü ile Salih ve Bilge'yi tanıştııılar. Üç ay konuşma sonrası evlilik hazırlığı başlar. Salih'in annesi ve Bilge daha düğün arifesindeyken bile anlaşamazlar. İki taraf da kendi istediğinin olmasında diretir. Salih annesi ile nişanlısı arasında sessiz kalır, iki taraf da 'Nasıl erkeksin, sözünü geçiremiyorsun.' ithamları ile birbirini şikâyet eder. Nihayet düğün olur ancak ilk gece Bilge, bekâretinin olmadığını söyleyince, kadınlara yaklaşmaktan korkan Salih iyice gerilir. Bilge samimiyetsiz bir şekilde sarılıp yakınlaşmak ister ama karşılık göremez. Burada Salih eşinin kendisini kandırmasından ve ardından yapmacık davranmasından rahatsız olmuştur. Üstelik Bilge ona iktidarsız diye hakaretler ederek kendini banyoya kilitler. Öfkesinin en üste ulaştığı anda erekte olan Salih çok şaşırır. Otelden ve tanıdığı herkesten kaçar, Kıbrıs'ta bir otele saklanır. Planlı bir şekilde intiharı dener, kutu kutu ilaçlar, böcek ilaçlarını yutar ama kurtarılır. Bir müddet sonra ailesine döner. 
Salih bebekliğinden beri acıyı tanıyarak, istenmediğini duyarak, hissederek büyümüştür. Bir de ergenliğinde, etrafında bilgi alabileceği hiçbir erkek olmadığı için derin suçluluk ve utanç duyguları yaşamıştır. Öte yandan başarılı bir baba ve ağabeyleri olduğu için kendisinden de bu beklenmiştir, ancak o çok da başarılı değildir. Ailesi koyu Müslümanken kendisi din kavramından uzaktır. Çünkü çocukluğundan beri evde gördüğü tüm dini ritüeller daima acı içinde yapılmıştır. Üstelik evliliği de oldukça kötü bir maceradır. Tüm bunların ağırlı̆ı altında ezilen Salih kendini suçlu, günahkâr, yetersiz beceriksiz görür ve mazoşistliği seçer. Salih'in hayatındaki kadınlar onun kimliğini hiçe sayarak ezmişlerdir. Önce ailede, anneden başlayan bu ezme, evliliğinin ilk gününde karısı Bilge tarafından cinsel kimliği ile küçümsenerek devam ettirilmiştir. Sevgi ve anlayıştan mahrum kalan, üstelik hayatındaki en belirgin motif eziyet ve aşağılanma olan Salih de bu bilinçaltındaki ezilmeyi tercihe çevirmiş ve hem suçluluk duygularından kurtulmak hem de cinsel doyum sağlamak için sadist kadınlara para ödeyerek mazoşizme teslim olmuştur. Bir 'domina'ya para karşılığı kendine işkence ettirir, bu işkence daha çok ruhsal şekildedir. Aşağılanmak, hakaret görmek, emir almak ve köle gibi kullanılmak, hükmeden kadına boyun eğmek ister. Bu yolda pek çok şeyi göze almış ve çok bilgi sahibidir. Doktor da böyle biriyle vaka olarak ilk defa karşılaştı̆̆ı için şaşırır, ondan bilgiler aldıktan sonra kendi de araştırmalar yapar. Salih yurt dışında mazoşizmin çok ileri boyutlarını görünce, kendisinin bir gün böyle olacağından korkarak yardım almaya karar verir. Onu anlayan ve kodlarını çözen bir kadın Doktor tarafından normale döndürülmüştür.

Doktor, cinsel kimlik bunalımı yaşayan, kendine sapık diyen Salih'in kaderine acır: "Bu yakışıklı, bu akıllı, zeki, duygulu çocuk, onun mutlu olmasını en çok isteyenler, onu korumak, kollamak için hiçbir fedakârlıktan kaçınmayanlar tarafından nasıl da yok edilmiş, bitirilmiş. Kastre edilmiş, erkekliği elinden alınmış. Ve eminim aile bütün bu bunların farkında bile değil... Annesini tanımıyorum ama eminim, oğlunun kılına zarar gelecek diye ödü kopuyordur. Bilmiyor ki, oğlunu kamçıyla dövüyor kadınlar! Bu tam bir trajedi..." (Budayıcıoğlu, 2017b: 187).

Salih'in görgülü, varlıklı ailesini yaptığı yanlışı aslında Anadolu'da görülmediğini ise şu sözlerle ifade eder: "Anadolu'da erkek çocuklar biraz büyüyüp bıyıkları terlemeye başladığında, hem evdeki hem de sokaktaki kadınlar ondan sakınmaya, ona saygı göstermeye başlar. Evde kimse onların yanında soyunmaya, çıplak gezmeye kalkışmaz. Zaten on sekizine geldiği an askerlik çağı gelmiştir oğulun. Çarşaftaki lekeler kimselere gösterilmeden, of pof çekilmeden yok edilir ortalıktan. Anne gurur duyar o zaman oğluyla. Hayat o anneyi çok ezse de o zayıf, o ezilmiş anne, sonunda güçlü, dünyaya kafa tutabilecek, önce annesini koruyacak bir erkek çocuk doğurmuş olmanın gururunu yaşar. Çarşaftaki lekeler olsa olsa bu zaferin kanıtlarıdır. 0 nedenle doğal karşılanır böyle şeyler. Kazma kürek tutuşturulur ellerine. Ağır işler onlara verilir. Çarşıya, alışverişe onlar gider. Oralarda hayatı tanımayanlar erkekler değil, kadınlar da değil, kızlardır. Başı bağlanan, çarşaflara sokulan, en küçük bir yanlışlarında başlarına vurulan, gizlisi saklısı olmadan, açıkça ezilen kızlar..." (Budayıcıoğlu, 2017b: 188).

Mazoşizmi kadınlarla ilişkilendiren Salih, kadınların bu konuda şanslı (!) olduklarını söyler. Zira hayatın içinde 'mazoşizmin alasını yaşa'dıklarını iddia eder. Ancak bu kadınlar mazoşist olduklarını farkında değildir. Bu tip kadınların kendisine geldiğini söyleyen Doktor, kocaların genelde alkolik olduğunu, öfke ve saldırganlığı kadına dayakla boşalttığını, kadınların da bilinçsiz bir istekle bunu beklediğini ve dahası böyle evliliklerin bitmediğini de söyler.

Mazoşizm eğiliminin kadınlarda gizli seyrettiğini öykü kahramanına söyleten yazarı Freud'un eserleri de destekler: "Kadınların, kendilerine yapısal olarak öngörülmüş ve toplumsal olarak dayatılmış olan saldırganlıkları baskılaması, bildiğimiz gibi içe doğru sapmış yıkıcı eğilimleri erotik olarak bağlamayı başaran güçlü mazoşistik itkilerin gelişimini destekler. Böylece mazoşizm, insanların dediği gibi gerçekten dişildir." (Freud,1998: 132-133). 
Doktorla bir yıl kadar görüşmelere devam Salih, mazoşizmden kurtulur ve artık çapkın bir erkeğe dönüşür. Hatta daha ileri giderek aynı anda üç sevgilisinin olduğundan bahseder. Ancak Salih normale dönünce kadınlardan kaçmasa da onlardan sıkılır. Tanışır tanışmaz yatağa gittiği kadınları eleştirir, onlardan soğuduğunu, duygusal bir şey hissetmediğini söyler. Ayrıca bu kadınların onu yatakta memnun etmeye çalışmalarını ve hemen evlilik hayali kurmalarını garipser. Duygusallığı olmayan kadın- erkek ilişkisini intiyaç gidermek şeklinde algılar. Salih garipsediği ama içinde olduğu ilişki biçimlerini şöyle eleştirir: "Bir iki saat içinde başlayıp yatakta noktalanan bir ilişkide bile başka bir şeyler arıyorlar. (...) Onlara hemen âşı olmamı, ertesi gün onlarla ilgilenmemi, arayıp sormamı hatta sonunda evlenmeyi bile bekliyorlar galiba. Aslında hepsi aklı başında, okumuş yazmış, meslek sahibi kızlar. Kimi benden önce en yakın arkadaşımla beraber olmuş, kiminin başkalarıyla yaşadıklarını, bizzat kendi ağızlarından duymuştum. En küçük bir elektrik, bu kızların yeni bir erkekle yatması için yeterli oluyor. Arada hiçbir duygusallık olmadan, bir ilişki, sadece cinsellik uğruna nasıl sürdürülür? Ben açıkçası sıkılıyorum onlardan. Cinsellik bitince hemen oradan kaçmak, uzaklaşmak istiyorum. Bir daha o kıza dokunmak istemiyor canım. Onlarda durum tam tersi. Seks bitince hepsi de sarılıp öyle uyumak istiyorlar. (...) Demek ki, eğer beraber olduğumuz kıza karşı duygusal bir şey hissetmiyorsak seks biter bitmez, biz erkekler için olay bitiyor. Ondan sonrası tam bir eziyet. (...) Biraz hoşlandığınız kızla, hemen o gece beraber oluyorsunuz. Böyle bir kıza bir şeyler hissetmek, onu ciddiye almak mümkün olmuyor." (Budayıcıoğlu, 2017b: 244-245) Öte yandan eskiden kadın iktidarına, acıyla teslim olan Salih kadınların öncelikle kendilerinin; erkekle eşitliğe alışkın olmadıklarını, erkek üstünlüğünü otomatik olarak kabul edip erkek memnuniyetini sağlayama çalıştıklarını düşünür. Bu konuda Doktor ona şu şekilde bilgi verir: "Bak işte bu doğru Salih. Kadın var olduğu günden beri hep fedakâr olmuştur. Önceliği içgüdüsel olarak erkeğe veriyor. Hâlbuki senin çevrendeki kızlar, cinsel özgürlüğünü elde etmiş, bu konuda kendini gelişmiş sananlar. Sanırım bu özellik, kadına annelik içgüdüsüyle birlikte geliyor. Sakın onları aşağılama. Unutma sen neysen, onlar da o." (Budayıcığlu, 2017b: 249). Salih'in bu düşünce sistemine erotizm ve romantizmin karıştırılması hâkimdir. Psikiyatrist Nevzat Tarhan, Salih'in de eleştirdiği ilişki biçimine şöyle bir açıklama getirir: "Kısa sürede cinsel ilişkiye giren kadına hiçbir erkek değer vermez.", Tek gecelik ilişkilerin erkekte erotizmi karşıladığını ve kadını değersizleştirdiğini ifade eder (2009:32-33).

"Günahın Üç Rengi" ve "Umuda Doğru" adlı son iki hikâye şaşırtıcı bir şekilde, eserdeki başıç kişilerin birbirleriyle temasını gösterir. Dördüncü hikâyedeki esas kişi Hayat'tır. Güzel, dikkat çekici 30 yaşlarında bir kadındır. Tesettürlü, bol bol mücevherler takıp takıştırmış bir hâlde, kliniğe kocasının zoruyla gelmiştir. Özellikle akşam içkiden sonra çok sinirli olmasından yakınır, sinirini yatıştıracak bir ilaç almak niyetindedir. Ancak Doktor ona ilaç verip göndermez, hayat hikâyesini anlattırır. Bu esnada eserin çözüm bölümü gelişir ve Hayat'ın aslında Meliha'nın, yangında öldü zannedilen kızı Melek olduğu anlaşılır. Ayrıca Şevket'in kadınlardan nefret etmesine sebep olan oteldeki kadın da Hayat'tır. Melek annesinin korktuğu bir şekilde yaşamışır. Lise çağlarındayken bir erkek arkadaşı ile geceleri evden kaçıp dolaşır sonra da eve girer. Yangının başladığı gece de evden kaçmıştır. Ancak biraz korkusundan biraz da macera seven ruhu yüzünden eve dönmez. Sevgilisiyle İstanbul'a kaçarlar, birkaç gün birlikte yaşarlar, oğlan ailesinin korkusu yüzünden Melek'i bırakıp döner. Melek ise en parlak ışıklı gazinoya gider ve olanları anlatır. Müdür onu evine götürür ve her gece bir başka adama satar. Melek'i güzel elbiseler, süslü giyimler mutlu etmeye yetmiştir. Yaşadıkları çok acı da olsa rahatsız değildir. Hatta istediği yaşamın bu olduğunu söyler. Babası annesi döveceği yerde parayla satılan adamların dövmesini yeğler. Çünkü annesi onu çok sıkar, süslenmesine, evde bile dans etmesine kızar. Bu sebeple o da ailesine çok kızar, asla dönmeyi düşünmez. Doktor bunu 'sevilmemişliğin, kabul görememenin' acısı olarak yorumlar. Aslında burada sevilmemişlik değil, annenin aşırı korumacı tutumu vardır. Ne yazık ki Melek bunu anlamadığı için annesine hınç duyar.

Melek 18 yaşına gelince Hayat ismiyle ona kimlik çıkarılır, sesi güzel olduğu için ders alır ve assolist olarak sahnelere çıkar. Bu onun en mutlu olduğu zamandır. Lüks içinde keyfince yaşamaya başlar, daha önce 
eline hiç para geçmezken şimdi para kazanmaya da başlar. Assolistlikten sonraki dileği zengin, yakışıklı ve kendisine çok âşık bir adamla evlenmektir. Tam da böyle bir adam, Cavit, karşısına çıkar, Hayat da ona âşık olur. Fakat Cavit Hayat'ı kandırmıştır. Evli ve dört çocukludur, zengin değildir, yaptığı gösterişlerin hepsi borç para iledir. Birlikte yaşamaya başlarlar, Hayat'ın tüm parasına bu adam el koyar ve kumarda bitirir. Hayat'ı gazinolara satar. Öte yandan onu öldüresiye dövdükten sonra yatağa alır. Hayat, Doktora, işin raconunun böyle olduğunu söyler. Hayat bu adamdan kaçmaz, onu kendisine arka çıkacak güçlü biri olarak görür. Ne zaman ki Cavit kumar için evdeki bozuk paraları alıp güçsüz bir şekilde evden ayrılır, o zaman Hayat onu terk eder. Çünkü güçlü gördüğü adam gözünden düşmüş, saygısı yok olmuştur. Gazinolarda kendisini uzaktan izleyen Galip'e gider, o gün tesettüre girer. Galip aşiretini karşısına alarak karısını boşar ve Hayat'la evlenir, ancak yıllarca aşiretin onları öldürmemesi için şehir şehir kaçarlar. Şevket Ağa, aşiretle görüşür ve onları affettirir. Kaçma biter, bir oğulları olur ve Hayat iyice kıymetli olur. Galip'in ilk karısından 5 kızı vardır ama onları pek sevmez. Burada başka bir hikâyede daha ortaya çıkar. Galip'in ilk karısı, vurulan abisinin karısıdır. Galip 14 yaşındayken yengesiyle evlendirilmiştir. Ancak bu kadın da Galip'in annesi gibi işten güçten kafasını hiç kaldırmaz, bütün günü ev işleri ve çocukla geçirir. Galip onunla geçirdiği günleri yok sayar, ondan olan kızlarla da Hayat'ın ısrarı ile ilgilenir. Galip Hayat'ı çok sevse de sevgisinin şiddetini dayakla (!) gösterir. Hayat'ı öldüresiye döver, sonra pahalı hediyelerle karısının gönlünü alır. Ancak burada Doktor'un bir tespiti dikkat çekicidir. Doktor, Hayat'ın kendini dövdürecek bir bahane aradığını söyler.

“- ...Kendini dövdürmek için çok uğraşıyor olmalısın. (...) Kim bilir kendini dövdürmek için nasıl da kışkırtıyorsun adamı. $\mathrm{O}$ da bu işin profesyoneli olmadığı için, dozu iyi ayarlayamıyor galiba. Bunları Cavit'le nasıl yaşadığınızı sen anlatmadın mı? Öyle olursa daha heyecanlı oluyor demedin mi? (...)

-Adamı ben kışkırtıyorum demek. Doğru galiba, çünkü aklım başımdayken pek yapmıyorum ama kafayı bulmuşsam, kendimi dövdürmenin bir yolunu buluyorum. Ama Galip, Cavit gibi değil. Nerede duracağını bilmiyor. Cavit insanı hastanelik etse de dövmenin usulünü bilirdi. Galip bilmiyor. Bir gün öldürecek beni.

-Hayır, o öldürmeyecek. Sen ona kendini öldürtmenin bir yolunu bulacaksın... Yapma, çocuğun var. (...) Intihar etmenin bir başka çeşidi bu." (Budayıcıoğlu, 2017b: 262).

Budayıcıoğlu'nın kadınların dayak yemesi ile ilgili hemen hepsinde yaptığı yorum, kadınların dayağı istedikleri ve suçluluk duygularından bu şekilde arındığı şeklindedir. Freud da bu konuda aynı şekilde düşünür: "Suçlulardan bir çoğunun cezalandırılmak isteğini duyduğunu biliyoruz. Yani, bu suçluların superego'ları bunu istemekte ve böylece kendileri ceza vermek zorunluğundan kurtulmaktadırlar." (Freud, 1981: 21).

Yazar Hayat'ın esas sorununu ise ilerleyen sayfalarda şu şekilde ifade eder: "Anneleri tarafından sevilmediklerini düşünen çocuklar, kendilerini sevmek, başkalarının da onları seveceğine inanmak ve başkalarını sevmek gibi temel güven duygusunu geliştiremezler." (Budayıcıŏlu, 2017b: 278). Hayat da annesinden hep azar işitip engellendikçe, dövüldükçe annesinin onu sevmediğini düşünmüş öfkelenmiştir. Hatta mezarı başına gidip onunla hesaplaşmışır. Ancak Doktordan, annesinin kendisini nasıl sevdiğini anladığında çok etkilenmiştir.

Yazar, bir çocuğun sahibi annesidir, cümlesini yer yer tekrarlar. Budayıcıoğlu'nun hastaların çoğunluğu anne sevgisinden mahrum büyüyen yetişkinlerdir. Freud bunu çok daha önce açıklamıştır: "Eğer bir anne yoksa ya da sevgisini çocuğundan çekmişse çocuk artık gereksinimlerinin doyurulacağından emin olamaz ve belki de en bunaltıcı gerilim duygularıyla karşı karşıya gelir." (Freud, 1998: 107). Doktora gelen hastaların pek çoğunda tıpkı buradaki gibi anne sevgisinin yoksunluğunu görürüz.

Hayat, Doktoruyla fahişeliğin en ince ayrıntılarını paylaşmış, o yolun başlangııından sonuna kadar başından geçenleri anlatmıştır. Neredeyse mesleğin gereklerini göstermiştir. Sadece öykü karakterini 
incelemenin yanı sıra bu tip kadınları ve hissiyatlarını anlamak bakımından eserdeki şaşırtıı bilgiler, gerçek hayattan alınması bakımından kayda değerdir. Bunlardan bazılarını şöyle sıralayabiliriz: Evden kaçmayı, evin baskısından özgürlüğe kaçmak gibi algılamıştır. 15- 16 yaşlarındayken kaçtığı zaman bile 'küçük bir kızı alıkoymak ve tecavüz'ün büyük suç olduğunu bilir. Kaçtığı çocukla hayatını geçirmeye niyeti de yoktur. Sesine ve güzelliğine güvenmektedir. Bu yüzden oğlan onu terk edince hemen heyecanla gazinonun yolunu tutar. Bekâretini kaybettiği için korkacak bir şeyi yoktur (!) gazino müdürü, evden kaçan küçük kızların başlarına belâ olduğunu bilir. Hayat, kimliğinin olmadı̆̆ını, kendisini ölü bildiklerini söyleyince adam onu evine götürür ve her gün başka bir adama satar. Hayat bu yaşantıdan memnundur. Ona göre hiçbir iş yapmaz, istediğini yer içer, süslenir, keyif sürer. Evi temizlemeye, eskiden hayat kadını olan yaşlı biri gelir ve Hayat'ı öğütler. En çok söylediği söz: 'Öl ama sakat kalma'dır. Hayat, küçük yaştan beri hem cinsel istismara uğramış, hem dövülmüş hem de üzerinden para kazanılan bir meta hâline dönüşmüştür, ancak o bu işin hâlâ eğlencesindedir. Erkekleri sevdiğini, kolay ve gösterişli yaşamı istediğini savunur. Ne var ki bu yaşamın içindeki eğlenceden çok bedeni ve ruhî tükenmenin farkında değildir. Assolist olduktan sonra hep öyle kalacağını düşünür, konsomatris kadınları küçümser; Cavit onu gazinoya satınca o da diğerleri gibi olur.

Hayatından memnun olduğu dönemlerde her gece başkasına pazarlanan çocuk gittiği adamları şöyle anlatır: "Ne derlerse onu yapardım. Çok hırpalarlardı beni. Hepsi yaşlı, sarhoş, ağzı leş gibi kokan adamlardı. Hiçbir şeyden utanmaz, beni her türlü kullanırlardı (...) Bir an önce şu iş bitse, onlar rahatlasa da ben de kurtulsam diye dua ederdim. Her yerimi çok acıtırlardı. Kimi de döverdi. Yapamadıysa, sanki bu benim suçummuş gibi basardı tokadı. Aman hepsi aynıydı. Önce yııışı yııışık güler, akılları sıra bana güzel sözler söyler, işin sonunda her şey değişirdi. Öğrenmiştim bunları. İ̧̧ bitince, sanki biraz önce benim için ölen, bana sarım sarım sarılan onlar değilmiş gibi uzak uzak kaçarlardı benden. Eve gelirdim ki, savaştan çıkmış gibi. Bütün vücudumda çürükler, morluklar olurdu. Gözlerimin altı çöker, sırtımda taş taşımıştan beter olurdum en çok da şeye kızardım... O leş kokuları üzerime sinerdi. Ertesi gün ne kadar yıkansam, o koku üzerimden çıkmaz gibi gelirdi bana." (Budayıcıoğlu, 2017b: 212). Hayat'a göre, bu meslektekilerin en rahat ettiği yer birbirlerinin yanıdır. Zira kimse kimseye bir şey diyemez. Çünkü çoğu kendi ayağıyla gelmiştir. Bazı kadınlar erkek akrabaları tarafından bulunup öldürülür. Hayat bu konuda işin raconundan (!) bahseder: Meslekte ölüm varsa kimsenin kılı kıpırdamaz. Ölenin insan yerine konmadığını, hâkimlerin bile katile ceza indirimi uyguladığını, en çok da kadınların kendilerini aşağıladığını söyler. Oysa ona göre normal kadınların çok sevdiği erkeklerin saldırgan olmamasının sebebi, amme hizmeti yapan hayat kadınlarıdır. Doktor bu kadınlar yüzünden yıkılan yuvalardan söz açınca, normalde hiçbir evli erkeğin bu yüzden karısını boşamayacağını iddia eder. Evdeki kadının suçlu olduğunu şöyle anlatır: "Adam zaten baştan bizim ne olduğumuzu biliyor. Bizi sevse de beğense de bu bir şey ifade etmez. Döner yine evine. Ama karısı geri zekâlı, kendini beğenmişin tekiyse, bir de üstelik beceriksizse, adama doğru dürüst karılık yapmayı bilmiyorsa, bunun suçu bizde mi? Hem öylesi çok seyrek gelir bize. Yıllarca bunun hayalini kurarız biz." (Budayıcıoğlu, 2017b: 217).

Meslekten şarkıcılığa, assolistliğe yükselen kadınlar masa masa gezmeyip sahneden inerse saygı görürler. Hayat ilk defa assolistken saygı ve takdir görür. Ancak bu meslekteki kadınların önce kendilerine saygısı olmadığı için, başkalarının da onlara saygı duymasının önüne geçmektedirler. Hayat assolistken, kazancını adamlara kaptıran dayak yiyen kadınlara kızar, kendisine verilen, 'birine kapılma yanarsın' öğüdüne kızarken tam da öyle olur. Güç ve para ikilisine âşık olan bu kadın, parayı kendi kazanabildiği için güçlü adamın yanında durur. Ancak gücün yok olduğunu görünce başka bir gücün yanına geçer. Bu tip kadınların dayak mevzusuna bakışı da ilginçtir. İşin gereği gibi görülür: "En küçük kusurumu affetmez, eşek sudan geline kadar döverdi beni. Önce döver, sonra alırdı yatağa (...) bu işlerde âdet böyledir Gülseren Hanım. Erkekler bu tür kadınları önce döver, sonra severler. Bunu hepimiz biliriz. O dayaklar belki de bunun için, bir yandan da heyecanlandırır bizi. Çünkü arkasından ne geleceğini biliriz. (...) Bizim gibi kadınlar, dayak 
yemeden rahat etmezler. Erkekler de bilir bunu." Bu meslekte en çok korkulan sakat kalmaktır. Ölümden korkmazlar. "Sakat insan orospuluk yapamaz. Hiç dostumuz olmadığından, ortada kalıveririz." (Budayıcıoğlu, 2017b: 225-226). Bu meslekte çalışanların gözükara olması gayet normal karşılanır. Hayat'ın evden kaçmaları, kaçtığı oğlandan sonra gazinoya gitmesi, Cavit'i bırakıp Galip'e kaçması Galip'i Şevket Ağa ile aldatmaya çalışması bunun delilleridir. Hayat aslında meslek içindeyken hayalini kurduğu bir evlilik yapmıştır. Çok güçlü ve çok zengin, kendisini çok seven bir adamla evlenip lüks içinde yaşamaktadır. Evinde hiçbir işe karışmaz, çocuğu bile bakıcılar elinde büyür ancak onun gözü hâlâ maceradadır. Hayat, Şevket Ağa'nın bakış açısı ile tam bir "femme fatale" tiptir. Bedeninin satılmasından, konsomatrislikten kurtulup, itibarlı zengin bir adamın namuslu eşi olmak yerine; kocasının dostunu ayartıp zevki uğruna herkesi ateşe atmayı göze alır. Doktorla yaptığı terapiler sonunda hayatını gözden geçirir ve içindeki her şeyi terapi sırasında dışarı çıkarır. Nihayetinde kendisinin yaşarken fark etmediği şeyleri görür ve Doktora akıllıca davranacağı sözünü verir.

Bu hikâyede, aile baskısı ile bir genç kızın zapt edilemeyeceği görülmektedir. Gerçeklerin öğretilmesi bu yolda daha ikna edicidir. Hayatta tek başına kalan bir kızın, başına nelerin geldiği nasıl sömürüldüğü oldukça ayrıntıı anlatılmıştır. Öte yandan bir kadının öncelikli olarak kendi iç saygısı yoksa hiçbir saygınlık elde edemeyeceği vurgulanmaktadır. Dünyanın en eski mesleği olan fahişeliğe içerden bir bakış olarak bu öykü sıra dışıdır.

Hayat, çocukluğunu yaşayamadan ev baskısı ile kaçmış, gençliğinde türlü erkeklere satılmış, istediği hayatı istemediği şekillerde yaşamış bir kadındır.

Romandaki kadın karakteri olarak Doktoru da ele alırsak, öncelikli olarak, yazarın kendisiyle ilgili verdiği bilgiler otobiyografik olarak doğruluk değeri taşımaktadır. Verdiği her bilgi biyografisi ile örtüşür. Öte yandan biyografisine eklenmeyen aile içinde olan, geçmişini gözler önüne seren bilgileri vermekten de çekinmez. Ancak bunu yaparken anlatacağı öyküyle bağlantısını kurar. Doktor, iyi bir ailede yetişmiştir. Kocasını ve çocuklarını seven bir annenin ilk çocuğudur. Bir kız, bir erkek kardeşi vardır. Anne yazara sorumluluk vermekten kaçınmaz, kardeşler ile hem oynar hem de abla olma sorumluluğunu taşır. Baba sevecen ve otoritedir. Evde saygı gören, dinini gerekleriyle yaşayan bir de babaanne vardır. $\mathrm{O}$ da çocuklarla ilgilenir. Sevgi ve saygının iç içe olduğu bir evde çocukluk geçirmiştir. Çocukluğa dair bilgileri bu şekilde sıralayabiliriz. Yazarın kendisi de sağlam temelli bir aile kurmuştur. Eşi Aydın’la meslektaşlardır, kızı Yağmur, oğlu Hasan ile sağııkı ilişkiler kurulduğunun işaretleri vardır. Bu sırada kızından olan Zeynep Su adlı torun da eserde zikredilir. Yazar, eşini fiziksel olarak da ruhsal olarak da çok beğenir. Onu kaybetmesi hayatında dönüm noktasıdır. Teselliyi çok çalışmakta ve okumakta bulur. Yazar, anne- kız ilişkisine çok değer verir. Kendi annesi ve kızı ile bu ilişkiyi belirgin kılar. Yazar, gece çalışmayı, müzik dinlemeyi, insanları ve işini çok sever. Kısacası yaşamın kendisini sever.

Doktorluk karakteri olarak kitaba yansıttıklarına bakacak olursak, en belirgin özelliği, insanı sevmesidir. Bir profesyonel olarak sorunu çözüp hastayı göndermez. Onunla duygusal bağ kurar, acır, üzülür, kızar. Insanlar ona sadece doktor olduğu için değil, bir dost gibi dinleyip bir doktor gibi çözüm sunduğu için gelirler. Hatta kimi zaman sadece sohbete gelmek isteyen bile olur. Klinik kurma fikri de hastalarına olan bağılıı̆ından ileri gelmektedir. Psikiyatri kliniğini hastane görünümünden uzak tutup, konforlu bir hâle büründürecek kadar da titiz düşünür.

Öte yandan dikkat çeken başka husus, her hastasına farkıı bir tavır takınarak, âdeta onların rollerine en yakın role bürünerek ilişki kurmasıdır. Burada şu sözleri, kendi izlediği yol hakkında bilgi verir: "Bir psikiyatr, karşısındaki kişiyi dinlemeyi ve kendini onun frekansına ayarlamayı çok iyi bilmelidir. Onu zorlamak, soru yağmuruna tutmaktan çok, onun hayatına sevecen, ön yargısız, hoşgörülü bir onur konuğu olarak girebilmektir." (Budayıcıoğlu, 2017b: 116). Psikiyatrist Irvin Yalom'un Bağışlanan Terapi (Yeni Kuşak Terapistlere ve Hastalarına Açık Mektup) adlı eserinde maddeler hâlinde verilen tavsiyeleri, Budayıcıoğlu 
öykülerinde, romanlarında hasta doktor ilişkisini kurgu içinde vermiştir. Budayıcıoğlu, Amerikalı meslektaşı gibi öğüt vermekten ziyade hastaya yaklaşımını anlatarak, uzun yıllar alan deneyimlerini edebiyata yansıtmıştır. Bu bakımdan, eserler yeni kuşak terapistlere ve hastalara öğüt mektubu değil uygulama referansı gibi yol gösterici niteliktedir.

\section{Romanlar}

\subsection{Hayata Dön ${ }^{5}$}

Roman tamamen kadın çatısı üzerine kuruludur. Kayda değer tüm kişiler kadındır. Kadınlar arası güç çatışması eserin her bölümünde kendini gösterir. ${ }^{6}$ Ala adlı genç bir kadın, Doktor Gülseren Budayıcıoğlu'ndan randevu alır ve olay çıkartmak ister, çünkü daha önceki doktorlar dürüst olmadıklarından içi öfke doludur. Ancak ilk kez Doktor Budayıcıoğlu, ona olabildiğince dürüst davranır ve bu hasta onu öfkelendirdiği için başka doktora yönlendirerek kabul etmez. Lakin Ala aradığı dürüstlüğü bulduğu için yoğun çaba ile kendini affettirir ve tedavi süreci başlar. Fakat Ala burada da normal hastalardan farklı davranır, konuşmaz, soruları cevaplamaz, kendiyle ilgili ipucu vermez. Doktordan kendisine hikâyeler anlatmasını ister. Doktor farklı bir teknik 'ajan-provakatörlük' deneyerek, ona çeşitli hikâyeler anlatarak, Ala'yı çözmeye çalışır, fakat vaka oldukça ağırdır. Öte yandan Doktor da kızdan çok hoşlanmadığı için, ona yakın bir bağ kuramadığı kendi içten içe kendini de yargılar. Seanslar boyunca Doktor ona, özellikle psikolojik etkileri olan olayları, kadınların tarih boyunca güzellik uğruna yaşadığı sıkıntıları ya da tarihteki önemli kadınların hikâyelerini anlatır, hikâyeleri Ala'nın çözülmesi için özenle seçer. Doktorun beklediği gerçekleşir, kopuk kopuk da olsa Ala bu hikâyelerle açılır ve kimliği, geçmişi hakkında bilgiler verir. Ala da bu süreçte Doktoruna güven duymaya başlar. Doktor hastası ile bağ kurar ve Ala daha önce kimseye anlatmadığı öyküsünü açar.

Ala'nın babaannesi Esma Sultan oldukça diktatör kişilikli, yaşlı ve huysuz bir kadındır. Etrafındaki kadınları en çok o ezer, bundan en çok gelinleri nasibini alır. Daha sonra Ala da Esma Sultan'ın ezdiklerinden biri olacaktır. Ala'nın annesi Süreyya gizemli bir kadındır. Ala'nın babasıyla birden bire nikâhlanıp İstanbul'dan gelmiştir. Güzelliği ile meşhurdur, ancak o bu güzelliği umursamaz. Umursadığı tek şey Esma Sultan'ın onayıdır, onun her hizmetini görür, yine de kimse onu sevmez. Üç kere çok güzel erkek bebek doğurmuş ama hepsi bebekken ölmüştür, nihayet çirkin ve kız bebek Ala doğmuş ama onu hiç kimse benimseyip sevmemiştir. Annesi hamile olduğunu bilmeden, babası sarhoşken birini öldürmekten hapse girer ve yedi yıl ceza alır. Ala, babası hapisteyken doğduğu için ona şaibeyle bakııı, üstelik annesi güzel, babası yakışıkııır. Bebek ise çirkindir.

Babaanne, büyük bir konakta, üç oğlu, üç gelini ve dört torunu ile yaşar. Bu evin istenmeyeni Ala'dır. O da sevilmediğini, istenmediğini bildiği için daima ağlar, ağladıkça hem azar hem dayak yer. Evde yatacak yeri bile yoktur. Annesinden hiçbir olumlu duygu, yaklaşım göremeyen Ala babasını bekler; ne var ki baba da aynı tavrı sergiler. Ancak en kötü anıları bunlar değildir. Esma Sultan'ı hamamda yıkama görevi Süreyya'nın, sıcak havluları tutma görevi de Ala'nındır. Esma Sultan da Süreyya da o gün oldukça öfkelidir. Babaanne, sıcak su döktüğü için Süreyya'ya bağııı ve tokat atmak isterken düşer, başını çarpar ve beyin kanamasından ölür. Banyoda olanları gören Ala'nın parmağı annesini gösterir. Ancak bu suçlama isteği ile olmasa bile ev halkı ve özellikle annesi tarafından suçlama olarak algılanır. Oysa terapide çıkan sonuca göre o, annesini suçlamak için değil annesine sığınmak için işaret etmiştir. Bu parmak hep sargılı, yaralıdır. Süreyya kısa bir müddet hapse girer, çıkar çıkmaz baba kızını ve Süreyya'yı Ankara'ya götürür. Ala'nın en

\footnotetext{
5 Illk baskısı 2011 yılında yapıımıştır.

${ }^{6}$ Bu eserdeki konu temelde aynı kalmak kaydıyla, farklı bir kurgu ile 3 Eylül 2017 tarihinden itibaren, ìstanbullu Gelin adında bir televizyon dizisi olarak yayınlanmaktadır. Senaristliğini de Gülseren Budayıcıŏlu üstlenmektedir.
} 
travmatik günleri burada annesiyle beraberken olanlardır. Anne Ala'yı öldüresiye döver, onu aç bırakır, ölmesi için uğraşır ama Ala hayatta kalmayı başarır. Ala'nın dövüldüğünü geç de olsa anlayan baba da anneyi aynı şekilde döver. Ancak Ala işkenceden kurtulmaz. Süreyya evde kendi kendine konuşup farklı hareketler sergilemeye başladıktan sonra, baba Süreyya'yı doktora götürmek ister, ilaç getirir ama Süreyya hepsini reddeder. En sonunda onu hastaneye yatırmaktan başka çare kalmaz. Süreyya o gün planlı bir şekilde Ala'yı banyoda sandalyeye bağlar, kendi intihar ipini, sandalyesini de hazırlar ve içindeki tüm kini Ala'ya boşaltarak, ona geleceği ile ilgili tehditler savurarak intihar eder. Öldükten sonra ipin kopması ile Ala'nın üstüne düşer. Annesi ona uğursuz olduğunu, ölmesi gerektiğini, ileride birlikte cehennemde yanacaklarını şimdi ise içine gireceğini söyleyip gülerek ölmüştür. Baba gelip Ala'yı hastaneye götürür, vücudunda kırıklar ezikler vardır, ama en büyük kırık ruhunda oluşmuştur. Günlerce konuşamaz, aklından hiçbir ayrıntı çıkmaz. Konuşmaya başladığında ise istemeden çocukluğundaki sesi ile konuşur. Babası da derin bir sessizliğe gömülür. Ala okula devam eder ancak asosyal olmasına rağmen birincilikleri toplar, yapılan ölçümde üstün zekâlı çıkmışır. Ala okuldakilere imrenir, ama hiçbiri ile konuşmaya cesaret edemez. İlişki kuramaz, çünkü bunun nasıl yapılacağını bilemez. Babası her gece evde içki içer, bir gün Ala babasını ölmüş bulur, artık kimsesizdir, ailesinden kimse yoktur, o artık çok zengin ama kimsesiz bir kızdır.

İçi nefret ve öfke doludur. Insanlara olabildiğince zarar vermek ister, tıp mı hukuk mu okuyacağı konusunda düşünür ve en sonunda adaletsiz dünyaya destek olmak için hukuk fakültesini dereceyle bitirip ceza hukuku konusunda çalışır. Terapi sırasında başka bir durum ortaya çıkar. Annesinin intiharı sırasında söylediği sözleri aktarırken, kendi tiz sesi yerine annesinin tok sesini kullanır. Ancak bu kısım bittikten sonra yine farkında olmadan iki sesten de farklı, güzel bir sesle konuşmaya başlar. Bu ses kontrolleri Ala'nın elinde değildir. Ala annesinin sesini kullandığında, onun ruhunun içine girdiğini düşünür, intihardan sonraki dönemde istemeden çocukluk sesi gelmiştir. Tedavi ile, olması gereken sesine kavuşmuştur.

Ala "yoksun annelik" durumu ile iç içe büyümüştür. "Çocuk, zayıf anneyle veya anneliği reddeden bir kadınla karşılaşması hâlinde "yoksun annelik" durumu yaşar. Çocukta ilk anda "çocukluk depresyonu" oluşur. Annelik yokluğunu, bu ilgi ve sevgisizliği ağlayarak protesto eder buna rağmen anneden sevgi alış verişi gelmezse, bu defa ümitsizlik dönemine girer, artık anne gelse de ağlar. (...) Her şeye ağlamaya başladığı ve anne gelse bile susmadığı dönem, depresyonda ümitsizlik dönemine geçildiğinin işaretidir. Daha sonra içe kapanma ve çözülme dönemine geçilir. (...) Çocuk dünyaya kapılarını kapar ve şizofreniye doğru gider." (Tarhan, 2009: 314). Ala'nın psikiyatre anlattığı çocukluk yaşam evrelerinin hepsi bu durumu kapsadığı gibi dahası da vardır.

Eserin başkarakteri Ala adlı genç kadındır. Romanın ilk bölümlerinde, olabildiğince çirkin, kaba, pis ve pasaklı bir görünüm arz eder. Saçı başı dağınık, kepekli, yüzü sivilceli, dişleri üst üste binmiş, burnu yüzüne göre kocaman ve aşırı zayıftır. Rahatsız eden tiz bir ses ile konuşur. Elbiseleri üstüne bol gelir, eski ve kirlidir. Öte yandan oldukça bilgili, zeki, başarılıdır. Yoğun bir sevgi açlı̆̆ı içindedir, insanlarla ilişki kuramaz, bildiği tek ilişki şekli dayaktır. Bu sebeple farklı erkeklerle birlikte olup onlara kendini dövdürür, bunu kendini cezalandırmak olarak da görür. İçi öfke ve intikam duyguları ile doludur. Yemek ve uykusuna dikkat etmez, sevdiği tek şey okumaktır. Güven duygusu, karşılaştığı her insanla zedelenmiştir. Illk defa Doktora güven ve sevgi duyar. Bu aynı zamanda eski alışkın olduğu güçlü kadın otoritesine boyun eğme ile ilgilidir. Doktoru ilk gördüğünde, onu Esma Sultan gibi güçlü kabul eder. Yıllarca annesinin intihar ederken söylediği sözlerin ve yalnızlı̆ının da etkisi ile bazen annesinin ruhuyla çatışma içinde, bazen de annesinin ruhuyla bütünleşip iki kişiyi bir bedende taşıyarak yaşar. Onun kıyafetlerini giymesi yalnızlığını unutmak içindir. Terapiler sayesinde kendini, geçmişini, ailesini detaylı sorgulayan Ala'nın değişim ve dönüşümü başlar. Ruhunu arındırır, Doktorun teşvikiyle Sekreter Tuna ile beraber, yaşına uygun kaliteli kıyafetler alır, klinikten, onun yaşlarındaki Psikolog Seliyha ile dışarıda görüşmelerini sağlayan Doktor onların arkadaş olmasına vesile olur. Seliyha onu güzellik merkezine götürür, burnu, dişleri ve ağzı plastik cerrahi ile 
düzeltilir. Diksiyon ve yürüme kurslarına gider. Ala tamamen farklı ve etkileyici bir güzelliğe kavuşur. Ancak yine de bu değişim ile içsel değişimi bitmiş değildir. Nihayetinde ağır hastalığından kurtulmuştur.

\section{Eserdeki diğer kadınlar Esma Sultan, Süreyya ve tabii ki Doktordur.}

Esma Sultan eserde salt otorite ve kötülüğün sembolüdür. Gelinlerine yakınlık göstermez, onları hor görür. Evde hizmetkârlar olmasına rağmen her işini gelinlerin özellikle Süreyya'nın yapmasını ister. Diğer iki gelinini kendi beğenip almıştır, ikinci gelin kendi gibi varlıklı bir ailenin ukalâ ve çirkin kızıdır. Esma Sultan ondan olan güzel torununu sever ancak Ala'dan nefret eder, onu dışlar. Üçüncü gelin ise fakir bir ailenin güzel kızıdır, bu gelin Ala'ya biraz olsun yakınlık gösterir. Esma Sultan, oğullarına nazlanır, hastalık numarası yapıp başına toplar. Oğullarının gelinlerle değil kendisiyle ilgilenmesini ister. Hatta fırsat bulunca oğullarına gelinlerini dövdürür. Yaşlandığı için kendini kadın gibi görmez, düğünlerde kadınların değil erkeklerin tarafında oturur. Büyük oğluyla iktidarını paylaşamaz. Evde çok saygı görmesine rağmen özellikle diğer kadınlar tarafından sevilmez. Gelinlere torunlara lâkap takar. Öldüğünde yası uzun sürse de kimse çok da üzülmemiştir.

Süreyya, Ala'nın kimliğinin oluşmasında her anne gibi büyük öneme sahiptir. Ancak o hiçbir zaman doğal ve normal bir anne modelinde değildir. Kendi ailesi yoktur. En çok Esma Sultan'a yaranmaya çalışır ama başaramaz. Ala bu yüzden annesine çok kızar. Sadece güzelliği ile olumlanır ancak bu da Süreyya'nın öne çıkardığı bir özellik değildir. Kocası, genellikle eve sarhoş olarak gelir ve onu aldatır. Bu aldatmayı da Esma Sultan bile bile Süreyya'ya duyurur. Güzel olduğu kadar becerikli olan bu kadını diğer gelinler de sevmez, sürekli çekiştirirler. Kendi kızına hem fiziksel hem ruhsal zulümler, işkenceler yapar. Geç fark edilen ruhsal hastalığı vardır, gaipten duyduğu sesler ona, kızının ölmesi gerektiğini söyler. Ala’ya yaptığı tüm işkencelerin sebebinin bu olduğu anlaşılır. Hastaneye yatırılacağı kesinleşince intihar ederek hayatını noktalamıştır.

Yazar sert anne babaların yetiştirdikleri çocukların da aynı tipte nesiller yetiştireceğinden örnekler sunar. Silsile hâlindeki öfke nöbetleri, anne-babaya duyulan öfkeye sonra kişinin kendine dönmesi ile ruhsal bozuklukların çıkmasına sebep olmaktadır.

Freud bu konuda söyledikleri ile yazarın anlattığı tipleri teşhis eder gibidir: "Kural olarak anne- babalar ve yetkililer çocukları eğitirken kendi super-egolarının emirlerine uymada benzerlik gösterirler. Egoları superegolarıyla ne tür bir anlayışa ulaşmış olursa olsun çocukları eğitmede sert ve zorlayıcıdırlar. Kendi çocukluklarının güçlüklerini unutmuş ve şimdi geçmişte onlara böyle sert kısıtlamalar uygulayan anababalarıyla kendilerini tümüyle özdeşleştirebilmiş olmaktan mutludurlar. Dolayısıyla bir çocuğun superegosu gerçekte onun ana-babasının değil ama ana-babasının super-egosunun modeline uygun olarak oluşturulur." (Freud, 1998: 88). Bu bağlamda Süreyya ve Esma Sultan gibi kadınların etkisindeki Ala'nın tüm dünyaya olan öfkesini anlamak zor olmaz.

Yazar burada, diğer rollerine göre farklı bir görünüm arz eder. Öncelikli olarak, ters insanlara ters yüzünün de var olduğunu göstermiştir. Öfkenin onu da yönlendirebileceğini ancak, yersiz öfke karşısında öfkelenebileceğine tanık oluruz. Öte yandan diğer kitaplarına oranla bu romanda kendi acılarını daha derinden anlatmıştır. Hayatında acıların zirveye çıktığını, unutmak istediği anların olduğunu, güçsüz, çaresiz anlarını okuyucuyla içten bir dille paylaşmışır. Eşinin, kızının hastalığı; oğlunun arkadaşını, kendi arkadaşlarını ve sonunda eşini kaybetmesi üst üste gelen acı olaylardır. Hayatının en zor dönemlerinde bile çalışmanın, okumanın onu tekrar toparladığını yazar. Romanda Ala’ya karşı oldukça negatif duygular içinde olan Doktor burada kendini anlayamaz. Ala'ya psikoterapi uygularken kendini de dinlemeyi ve çözümlemeyi ihmal etmez. Doktor, Ala yüzünden, sevgi dolu ve müşfik kalıbından dışarı çıkmıştır. Ancak Ala'nın hikâyesine dâhil oldukça ona da kalbinde yer açmıştır. Doktor bu eserinde kurucusu olduğu kliniğin işleyiş sisteminden de bahseder. Doktorun kendini anlattığı bu bölümler, roman içinde otobiyografik değer taşır. Doktor mekâna, dekorasyona evinde de işinde de önem verir. Müzik onun için önemlidir. Kahveyi 
sever, özellikle iş yerindeyken yemeyi unutur, mide rahatsızlığı çekse de hastaları önceliklidir. Burada önceki eserlerinde olduğu gibi sigara içtiğinden bahsetmez. Aile sevgisi her kitabında olduğu gibi burada da yerini korur.

Ayrıca yazar, kliniğe gelen başka kadınlardan bölüm aralarında bahsetmiştir. Onlarla ilgili bize şu bilgileri verir: Hülya Sakoğlu eşiyle aralarındaki anlaşmazlık ile gelmiştir. Eşi Aslan Bey çok otoriterdir, karısını ve iki oğlunu sevse de onları korumak adına çok sert davranır. Sertliği, geçmişinde annesini küçük yaşta kaybedip üvey anne ve haksızlıklar karşısında aldığı savunma durumundan kalmıştır.

Uyumlu ve uysal görünümlü, kırklı yaşlardaki İclal Hanım ise başka bir vakadır. Kocası getirmiştir, günlerdir yemez, içmez ve uyumaz, üstelik kendi kendine konuşmaya başlar. Normalde çok sessiz ve uyumlu olan, insanlarla çok iletişim kurmayan, içe kapanık bir kadındır. Kocası onu çok sever ve sosyalleşmesi için kurslara gönderir. İclal Hanım, son gittiği Kur’an kursundan beri çok değişmiştir, ibadete önem verir, saatlerce namaz kılar ancak abdesti bile yoktur. Rüyasında Peygamberin ona göründüğünü, çok önemli görevleri olduğunu söyler. İclal Hanım’a paranoid durum bozukluğu teşhisi ile tedaviye başlanır. Yazar bu kısımda hastalıkla ilgili bilgiler verir.

Doktorun aktardığı bir başka vaka 36 yaşındaki Ayşe'dir. Bu kadın hasta olmasa da kimseye anlatmadığı, suçluluk duygularını aşamadığı bir olayı anlatmak için gelmiştir. Beş yaşındayken, kendi yaşlarında bir kız ve iki erkek arkadaşıyla birbirlerine cinsel organlarını göstermişleridir. Çocuk, olanları annesine anlatınca, anne kızını günahla korkutup azarlar. Annesi ile tekrar konuşmak ister. Ancak annesi konuşmaz, çocuk suçluluk duygusuyla sürekli ağlar, ağladıkça da dayak yer, gittikçe hırçın ve anlaşılmaz olur. Beş yaşından, otuz altı yaşına kadar kendini suçlu, kirli hisseder. Üniversite okur, evlenir, iki çocuğu olur bu süre içinde kendini ezik güvensiz, mutsuz hisseder. Doktor burada bir annenin tek bir tepkisinin bir hayatı nasıl karartabileceğini gösterir. Ayşe'ye günahkâr olmadığını anlatır.

Gülten ise başka bir bölümde hikâye edilir. Daha önce, kocasıyla anlaşmazlı̆̆ı yüzünden Doktora gelen Gülten yıllar sonra kayınvalidesi için gelir. Seksen yaşındaki kadın, eşini kaybettikten sonra evine bir de hırsız girince huyu tamamen değişmiştir. Evdeki hiçbir şeyi atmaz, gittiği yerlerden ufak tefek şeyler aşırır. Titiz bir kadın olmasına rağmen artık temizliğini bile defalarca kullanılmış, kirli sularla yapmaktadır. Doktor bunun hastalık olduğunu belirterek ilaç verir. Burada Gülten adlı kişide fedakâr kadın tipini görmekteyiz. Kocası ve kayınvalidesi onu çok üzmüş olsa da zamanı geldiğinde onlara yardım edebilmek için elinden geleni yapmaktadır. Kayınvalide ise kocasının ölümü ve hırsızlık ile aç açıkta kalma korkusu ile hastalanmıştır.

Güzel yüzlü Serpil Hanım ise oğlundan şiddet gördüğü için gelir. 16 yaşında zengin ama çok kıskanç bir adamla evlendirilen Serpil Hanım kocasından sürekli şiddet görmüştür, iki oğlu olmuştur. Bu kez de 16 yaşındaki büyük oğlu anneyi dövmeye başlar. Doktor bu vakada ailenin tamamının incelenmesi düşüncesiyle hastayı başka bir meslektaşına devreder.

Bir başka hikâye Sündüs hanımınkidir. Kendisi için değil, çok sevdiği oğlu için gelmiştir. Oğlu homoseksüel olduğunu itiraf edince ne yapacağını bilemez. Doktor durumu uzun uzun açıklar. Sündüs Hanımda müşfik ve gayretli bir anne motifi görürüz.

Kadın ve erkek eşcinselliğini ve bedenlerini satan bu tip kişilerle röportajlar içeren Kadında ve Erkekte Eşcinsellik adlı kitap, tıpkı Budayıcıoğlu'na gelen kişilerde olduğu gibi kişilerin toplumsal dışlanma korkusunu, aynı meslekte olanların bile birbirini nasıl aşağıladığını, lanetli olduklarına inandıklarını aktarır. Budayıcıoğlu'nun Hayata Dön kitabında, eşcinsel oğlu için Doktora gelen bir anne ile yukarda adı geçen kitaptaki annenin çocukları için taşıdıkları endişe birebir aynıdır. Her iki anne de çocuklarının bu hastalıktan kurtulmasını ister. Ancak psikolojik danışmanları bunun hastalık değil yönelim olduğu konusunda annelere bilgi verir. 
Eserde kadınların gerek fiziksel, gerek ruhsal, çektiği tüm sıkıntılara örnek olacak birer vaka içermektedir. Bu sıkıntıların en temelinde yatan sebep iletişimsizlik ve sevgisizliktir.

Ala'nın kadınlar konusunda söylediği şu sözler gerçek hayatta var olanın tespiti gibi gözükmektedir. "kadınlara yapılan eziyetlere... yine kadınların destek vermesi ne garip!.. (...) Törelere destek olanlarda yine kadınlar... Kadın istemese erkek hiçbir şey yapamaz. Ama kadın böyle istiyor... Ceza istiyor... Acı istiyor... Hatta sonunda ölümü istiyor." (Budayıcıoğlu, 2018: 107).

Doktorun, Ala'nın çözülmesi için anlattığı hikâyelere şu konu başlğı taşır. Güzelleşmek uğruna çekilen çileler: takılan korseler, yüzlere sürülen kimyasallar, Çin'deki lotus ayak uygulaması vb. Avrupa'daki cadı avında yakılan kadınlar, Prenses Süreyya, Çariçe Katerina'nın sırf kadın oldukları için yaşadıkları acılar... İspanya'daki fısıltı sanatı, Eva Peron, Freud ve Hitler... Konulara bakıldığında, tarihte ve kişisel tarihlerinde acı ile iç içe yaşayan kadınların özellikle seçildiği dikkatleri çeker.

Tanzimat dönemini aile açısından inceleyen Dilaver Cebeci, "Sevgi, fedâkarlık, şefkat, bölüşme arzusu, hatta konuşma kaabiliyeti gibi bir çok özelliklerin kazandırıldığı yer ailedir. Muntazam bir aile hayatı yaşama imkânı bulamamış fertlerin derûnî âlemlerinde büyük rahatsızlıklar meydana geldiği müşahede edilmiştir. Huzurlu bir aile hayatından mahrum büyümüş insanlarda bedenî bozukluklar dahi görülmüştür." (Cebeci, 1993: 9) diyerek eserine giriş yapar. Budayıcıoğlu'nun gerek öykü gerekse romanlarını incelediğimizde de karşımıza bu düşüncenin doğruluğu çıkmaktadır. Ailedeki bozukluklar çocuklarda mutlaka tezahür etmektedir.

\subsection{Kral Kaybederse ${ }^{7}$}

Ankara'da, 1980'lerde başlayıp 2013'te biten hikâyede kırsal bölgeden gelen bir genç kızla, orta yaşların sonunda zengin, yakışıklı, evli bir adamın aşk hikâyesinin art plânında toplumun farklı kesimlerindeki insanların psikolojik tahlilleri yapılmaktadır. Eserin konusu iki kadın- bir adam hikâyesi olarak klasikleşmiş gibi görünse de oldukça ilginç bir sonla okuyucuyu şaşırtmaktadır.

Eserin başkişisi Kenan Baran'dır. Ancak onu bir romanın başkişisi yapan hayatındaki kadınlardır: Başta, karakterinin ilk ve en belirgin halkasını oluşturan annesi, babaannesi; karakteri oluştuktan sonra da hayatını şekillendiren eşi Handan Hanım ve Fadi. Bunların haricinde çekiciliğine kapılarak etrafını saran, onunla cinselliğe dayanan ilişkiler kuran pek çok kadın da Kenan Baran'ı oluşturan diğer halkalardır. Eserdeki kadınları daha belirgin olarak çözümlemek için, önce Kenan Baran'ın nasıl bir yapıda olduğunu görmemiz gerekmektedir. Buna göre o, fiziksel özelliği ile öne çıkan bir karakterdir. Oldukça yakışıklı, uzun boylu, yeşil gözlü, siyah saçlı, güzel bir ses tonu ile girdiği her ortamda gözleri üzerine çekebilecek bir etkileme gücüne sahiptir. Bunun yanı sıra ilk gençliğinden beri oldukça şık giyinir. O zamanlar yoksul sayılsalar bile zenginleştikçe giyim kuşamına önem vererek bu konuda da kendini ön plana çıkarır. Vazgeçemediği etkileyici parfümü ile de koku hafızası oluşturmaktadır. Bir de yanından ayırmadığı aksesuarı deri çantası vardır. Bu görsel özelliklerden sonra psikolojik özelliklerine bakabiliriz.

Annesi tarafından el bebek gül bebek şekilde büyütülmüştür. O iki-üç yaşlarındayken annesi hastalanarak Bakırköy Hastanesinde kaldığı için annesinden ayrılıp babaannesinin bakımına verilmiştir. Ancak Kenan babaannesini hiç sevmemiştir, hatta ona benzeyen yaşlı, çirkin ve şişman kadınlardan da nefret etmektedir. Bu süre içinde bebek Kenan da hastalanmış ve hastanede yatarak tedavi görmeye başlamıştır. Bu anılar onun zihninde gerilere itilse de oldukça canlıdır. Hastanedeki yalnız ve kötü günleri onun korkularının temelini oluşturmuştur. Hastanedeyken babası kısa süren ve sevgiden uzak ziyaretler yapar. Bir çocuk için uzunca sayılacak bir süreden sonra annesi onu hastaneden çıkarmaya gelir ve oğlunu

\footnotetext{
7 ilk baskısı 2015 yılında yapıımıştır.
} 
'kurtarır'. Bu metafor onun zihninde daima kalmışır. Hayatındaki her kötü anda, bir kadının gelip onu kurtarmasına muhtaçtır. Çocukluğunda ve yetişkinliğinde annesi ona hep "kralmışçasına" davranmıştır. Annesi öldüğünde uzun zaman kendine gelememiştir. Babası hayatında oldukça silik bir şekildedir. Onu kıskanç, mutsuz, sarhoş ve silik biri olarak hatırlar. Baba-oğul ilişkisine baktı̆̆ında Doktor Kenan'ın davranışlarını, 'babasının aksine sıra dışı ve tam bir erkek olma çabası' olarak nitelendirir. Kenan ilk gençliğinden beri dikkatleri üzerine çeker. Hatta neredeyse kızlar onun üzerine gider. Kenan da bundan kaçmaz böylelikle çapkınlığı doğal olarak üzerine yapışır. Kadınlar konusunda 'hiçbir fırsatı' kaçırmaz. Çapkınlığını, ne evliliği ne de uzun süren sevgilisi engelleyebilmiştir. Pek çok kadınla eş zamanlı birlikte olmak onun için bir hayat tarzına dönüşmüştür. Hayatında daima her şeyin kolay tarafına alışmıştır. Sürekli onaylanan, işleri rast giden her yönden çok talihli olan bu adamın hayatı, Fadi'nin onu terk etmesi ile ters yüz olmuştur. Etrafında pervane olan bir anne, her türlü intiyacını gideren, hiçbir kusuruna ses çıkarmayan, çapkınlıklarına göz yuman bir eş, kendisini 'kral gibi hissettiren' ve taparcasına seven bir sevgili Kenan için kazanılmış haklardan ibaret gibidir. Bunun yanı sıra erkek arkadaşlarına hiçbir zaman güvenmez, daima kendisini kıskandıklarını düşünür. Doktor bunu babasının ilgisizliği, sevgisizliği ve hastane odasındaki terk edişlerine bağlar. Kenan'ın başlıca karakteristik özellikleri sorunlardan kaçmak ve yalnızlıktan korkmaktır. Mevcut herhangi bir sorun onun çözebileceği bir şey değildir. Sorun, başkası, özellikle bir kurtarıcı kadın tarafından, çözülecektir. Kadınlarla hayatı boyunca flortiz ilişkiler kuran Kenan, bir kadınla başka türde bir ilişki kurulacağından habersizdir. Onun hikâyesinde arkadaş, meslektaş, kız kardeş, teyze, hala gibi bir kadın rol modeli yer almamıştır. Hayatı âdeta bir anne ve pek çok sevgiliden oluşmuş bir çerçeve içindedir. Bu yüzden gittiği kadın doktoru bile 'tavlama' peşindedir. Ne var ki bunca kadınla olan ilişkisinde hiçbir zaman aşk ile karşılaşmamıştır. Bir kadın onun için sadece heyecan vesilesi olan cinsel kimliğinden ibarettir. Onun en büyük korkusu yalnız kalmaktır. Bu yüzden hayatındaki kadınları hep birkaç yedeğiyle (!) birlikte tutmaktadır. Kadınlar konusunda, biri giderse biri gelir düşüncesine sahiptir. Hiçbir zaman bundan rahatsız olmamıştır, hayatında hem karısının, hem Fadi'nin sabit kalmasını hem de farklı sevgililerinin olmasını istemiş ve bunu da uygulamıştır.

Kenan'ın hayatının kırılma noktası olan, Fadi'nin onu döverek terk etmesinden sonra artık o bambaşka bir kişiye dönüşmenin âdeta kabuk değiştirmenin ilk safhasına girmiştir. Hayatı boyunca hem aşkta hem kumarda kazanan, yakışıklılı̆ı, zenginliği, öz güveni yerinde hatta fazlası olan Kenan bu noktadan sonra artık her şeyde kaybeden olmuştur. Önce dayakla kafası kırılan, daha sonra bu hâdiseyle panik ataklar geçiren, sayısız kez farklı doktorlara giden sağlığını kaybeden Kenan daha sonra kadınlarla olan ilişkisini yitirmiş, eşi tarafından da boşanmıştır. Daha sonra yakışıkııı̆̆ı öz güveni, zenginliği, arkadaşları tek tek kaybettikleri arasına katılmışır. Tüm bunlardan sonra itibarı da kaybettiği en değerli hazinesi olmuştur. Bu süreç içinde Doktor Gülseren Budayıcıŏlu ile tanışmıştır ancak Doktorun tavsiyelerine kulak asmamış, sadece fiziksel sıkıntılarına çözüm olarak onun verdiği ilaçları kullanarak rahatlamışır. Doktorun onun çöküşünü durdurmak için yaptığı her tavsiyeyi geri çevirmiş ve git gide derin ve hızlı bir çöküşe girmiştir. Artık onu seven tek bir kişi bile kalmamıştır. Lâkin o hâlâ iyileşmek, mevcut durumu düzeltmek değil geçmiş günlerini tekrar yaşama peşindedir. En sonunda ölümün eşiğinden dönüp, güç belâ, özel bir huzurevine yerleşmesine rağmen tüm enerjisini yine hayallerine harcar. Bu sırada, uzun bir aradan sonra yine Doktoruna gider. Doktor son bir kurtarma hamlesi ile, 'Bu şekilde devam ederseniz hayatınızda artık ben de yokum, ölürken yanınızda ne götüreceksiniz?’ gibi cümlelerle sarsıcı bir atağa geçer ve yılların değişmeyen Kenan'ını kendine getirecek cümleleri sarf eder.

Fadi'den sonra düşüşe geçen ve en diplerde sürünen Kenan'ı yukarı çekecek olan; yine bir kabuk değiştirme safhasına sokan işte bu son görüşme olmuştur. Kenan bu tepkiden sonra artık adım adım kendi yaralarını sağaltan, iyilik hamleleri yapmaya çalışan, hayatı yeni baştan kurmaya çalışan birine dönüşmüştür. Huzurevinde aylarca kimseyle iletişime geçmemiş, acil doktorlarını yıldırmış, huysuz ihtiyar olan Kenan 'ölmeden önce insanlardan gülümsemeler toplamaya' karar vermiştir. Tek kendine değil 
başkalarına da değer vermeye başlamış, kendini maddesel değil manen beslemiştir. Sırf bu yüzden, ömrünce görmeye bile tahammül edemediği yaşlı ve şişman bir kadınla, evlenerek maaşının öldükten sonra ona bağlanmasını sağlamıştır. Yıllarca çalışmayıp ele güne muhtaç duruma düşen Kenan huzurevinde çalışarak, en son evlendiği kadının torununa, 'evladım' dediği çocuğa, tekerlekli sandalye almış, yürümesini sağlayan ameliyata maddi kaynak oluşturmuş ve eline geçen yüklüce bir parayı onlara ev almaları için vermiştir. En sonunda tüm bu değişimini Doktoruna yazarak maddî manevî değişimine Doktorunu ve onun hikâyesini okuyan herkesi şahit tutmuştur. Kenan'ın bu yazıları, ölümünün ardından, huzurevi arkadaşı tarafından Doktora ulaştııımıştır.

Kenan'ın tahlili nispetinde romanı özetledikten sonra, romandaki ve gerçek hayattaki kadınları yazarın verdiği bilgilere göre ele alabiliriz.

Kenan'ın annesi: Oldukça güzel bir kadındır. Kenan fiziksel özelliklerini ondan almıştır. Kenan'ın babası başka bir kadınla evliyken onunla ilişkisinden Kenan'a hamile kalmıştır ve babası bu yüzden ilk eşini bırakıp Kenan'ın annesiyle evlenmek zorunda kalmıştır. Kendinden önceki kadınla ilgili 'köylü tipli' bir kadındı diyerek küçümseyici ifadelerde bulunur. Evlendikten sonra kocasıyla da mutlu olamamıştır. Kayınvalidesi ile arası hiçbir zaman iyi olmamıştır. Kenan daha çok küçükken Bakırköy Hastanesinde yatmıştır, çıktıktan sonra oğlunu da hastaneden kurtarmıştır. Oğluna karşı her zaman çok aşırı korumacı olduğunu görmekteyiz. Oğlu büyüyünceye dek onunla birlikte uyumuştur. Çocukluğunda Kenan'ı koruma pahasına oyun bile oynatmamıştır. Kenan büyüyüp genç olduktan sonra bile onu her türlü tehlikelerden korumaya çalışmıştır. Kocası öldükten sonra yıllarca genç yaştaki Kenan’la dertleşmiş, bir kadının ne istediğini, hayallerinin, beklentilerinin ne olduğunu anlatmıştır. Böylelikle Kenan genel olarak kadınların ne istediğini anlamaya başlamış, onları tavlayacak (!) kıstasların ne olduğunu çözmüştür. Anne, oğlunun ne idüğg̈ belirsiz bir kızla evlenmesinden çok korkar. Ara sıra büyücü hoca gibi kişilere giderek oğlunu koruyacağını düşünür. Gelini ile pek muhatap olmamış yine sadece oğlu ile iki kişilik bir dünyada yaşamaya devam etmiştir. Öldüğünde 84 yaşındadır. Doktor Kenan'ın annesi ile ilgili bu bilgileri aldıktan sonra Kenan'ın karakter kodlarını çözmeye başlamıştır. Bu bağlamda Kenan'ın yalnızlık korkusu annesinden çok küçük yaşta ayrı kalması ile ilgilidir. Bir kadın tarafından kurtarılmayı beklemesi, annesinin onu hastaneden çıkarmasıyla ilişkilidir. Kadınlar hakkında çok bilgiye sahip olması annesinin ona kadınlar hakkında uzun uzun bilgi vermesine bağlıdır. Kenan'ın düşüş yaşadıktan sonra hocalara gitmesi, nazara geldiğini, büyü yapıldığını düşünmesi annesi ile ilgilidir. Bütün bunları göz önünde bulundurduğumuzda, Kenan’ı kralığa alıştıran annesidir, tezini ileri sürebiliriz.

Kenan'ın babaannesi: Kenan'a, annesi hastayken bakmıştır ancak sevgi ve ilgi ile değil horlayarak bakmıştır. Gelinini sevmemiştir. Tombul bir kadındır. Kenan babaannesini hatırlatacak tipteki kadınlardan daima nefret etmiştir. Annesine "deli gelin, kahpe" gibi sözler söylediğini işitmesi de babaanneye karşı olumsuzluğu devam ettirmiştir. Kenan, babaanne bakımındayken, hastanede yatacak kadar hastalanmıştır. Doktor bunu anneden ayrılmaya ve sevgi yoksunluğuna bağlamaktadır.

Handan Hanım: Handan Hanım oldukça zarif, alımlı, akıllı, sabırlı bir kadındır. Mimar olmasına rağmen çalışmayıp bütün ömrünü eşine adamıştır. Kenan'ın üniversiteden arkadaşıdır. Kenan'a daima hayrandır ama diğer kızlar gibi onun peşinde hiç koşmamıştır. 'Sabırla' Kenan'ı beklemiştir ve sonunda onunla evlenmiştir. Ancak kızların Kenan'a olan ilgisinden, Kenan'ın onlara tavrından da daima haberdardır. Evliliklerinden kısa bir süre sonra yakın arkadaşı Özlem ile Kenan'ın ilişkisi öğrenip hemen boşanmıştır. Kenan da Özlem'le evlenmiştir. Handan Kenan'ı unutamamış psikolojik olarak kötü günler geçirmiştir. Kenan'la tekrar iletişim kurmuş bu kez aldatılan değil aldatan olmuştur. Özlem bu yüzden boşanınca, Kenan'ı bir daha asla bırakmamak üzere, ikinci kez Kenan'la evlenmiştir. Ancak kocası aynı çapkınlıklara devam etmiştir. Boşandıktan sonra çektiği aşk acısı yüzünden, Kenan'ı bir daha asla terk etmeyeceğine dair kendi kendine söz vermiştir. Kenan bebek istememesine rağmen, kocasını eve bağlamak için hamile kalmıştır. Kenan'la kavga ettikleri bir gün bebek erken doğum sebebiyle ölmüştür. Bu olaydan sonra karı 
koca ilişkileri oldukça soğumuştur. Handan Hanımın psikolojisi bozulmuş ama evliliğine hiçbir şey olmamış gibi devam etmiştir. Kocasının kendisi defalarca aldatmasını bilmesine rağmen ses çıkarmamıştır. Bu konuda kendini suçlamıştır. Çünkü Kenan'ın huyunu bilmesine rağmen onunla evliliğini bitirememektedir. Yazar bu konuyu da Handan'ın babası ile ilişkisine ve annesinin babasına olan tavrına bağlamaktadır.

Handan'ın annesi fakir bir ailenin güzel kızıdır. Kocasına hizmette kusur etmez ama yine de hor görülür. Handan'ın babası kaymakamdır. Çirkin bir adamdır, yüzü gülmez ve otoriter bir babadır. Karısı kendinden gençtir, güzeldir ama o yine de karısının yaptığı hiçbir şeyi beğenmez, her şeyine kusur bulur. Handan'ın annesi öldükten sonra yaşadıkları konağın idaresi 12 yaşındaki Handan’a kalmıştır. $O$ da annesi gibi babasından çekinir, evi çekip çevirir, evdeki çalışanları da idare eder. Üniversite için evden ayrıldığında babası yeniden genç bir kadınla evlenir ve siyasete girerek zenginliğini yitirir. Yazar, Handan'ın Kenan'a âşık olmasını babasının çirkinliğine bağlar. Sabrını, evinin her türlü işi ile ilgilenip Kenan'ı hoş tutmaya çalışmasını ise annesine bağlar. Handan Kenan'a bir anne gibi bakar, bu da Kenan'ın beklediği ilgidir. Ne var ki Kenan'ın yaptığı her şey onun gururunu her geçen gün incitmiş şahsiyetini içten içe yok etmiştir. Handan Hanım Kenan'a taht kurmuş ve onu her zaman kendinden üstün tutmuştur. "Hayattan korkan, özgüveni eksik kadınlar, eşlerinin her dediğine evet derler. Duygularını bastııılar. Kendi kişilik sınırlarını yok sayarlar. Sabırlı olmayı 'içine kapanık olmak' olarak algılarlar ve ruh sağlıkları bozulur. Erkek de hep almaya alıştığı için bencilleşir. Eşinin duygularını önemsememeye başlar. Başka arayışlara yönelir." (Tarhan, 2009: 33). Handan Hanım ve Kenan'ın ilişkileri de bu yolda ilerleyerek bitmiştir. Bunu ancak Fadi'nin Kenan'ı dövdüğü gün son haddinde hissetmiş ve Kenan'ı bırakmaya karar vermiştir. Yine de kocasının hastalı̆ını atlatmasını beklemiş, kendi deyimiyle 'onun kendisine en çok ihtiyacı olduğu zamanda' terk etmiştir. İçindeki tüm duyguları Doktor'a giderek anlatmıştır Kenan'dan ayrıldıktan sonra memleketi Bursa'ya yerleşmiş, bir müddet sonra da 'babası gibi yaşı' bir adamla evlenmiştir. Ancak Kenan ortada kaldığında onun için huzur evi bulup yerleştirmiş, son görevini yapmıştır. Doktor onu çok iyi bir insan olarak nitelendirir. Özelliklerini değerlendirmeye tabi tuttuğumuzda onun çok fedakâr, vefakâr hatta gereğinden fazla şeye göz yuman bir Türk kadını temsili olduğunu ileri sürebiliriz.

Eserin ikinci önemli kişisi Fadi'dir. Onun karakter özeliklerinden ziyade roman içinde yer aldığı kadarıyla hayat hikâyesine bakmak gerekir:

Fadi/ Fatoş Hanım: Asıl adı Fadime'dir. Bir kırsalda ailesinin beşinci kızı olarak doğmuştur. Bu sıralama onun hayatını belirleyen temel etkendir. Çünkü babası, annesini bu kez de kız doğurursa onu boşayacağı tehdidini savurmuştur. Annesi onu doğurduktan sonra çok üzülmüş, bakımsız bırakmış, uğursuz olduğuna hükmetmiştir. Eve gelen bir misafir bebeği sevdikten sonra trafik kazasında ölünce adı iyice uğursuza çıkmıştır. Ne yapsa annesine babasına yaranamamıştır. Çocukluğunda kucağa bile alınmamıştır. Hatta sürekli anne babasında kötü söz duymuş ve dayak yemiştir. Sevgi açlığı içinde, merhamet duygusundan uzak büyümüştür. Kendinden önceki kızlar da aynı kaderi paylaşmaktadır. Baba hem eve 'boyalı oynak kadınlar' getirip hem de kızları ve karısını dövmektedir. Babasını gülerken gördüğü anlar eve 'o kadınlar'ın geldiği günlerdir. Kızlar babasının o anda güldüğü gibi gülen adamlarla evlenme hayali kurmaktadırlar. Baba bir gün karısı ve kızlarını kovup ikinci kez evlenmiştir. Birkaç hafta sonra da aynı eve ilk karısı ve kızlar tekrar gelir. Kuma onlara iyi davransa da ev çocuklar için iyice cehenneme döner. Babasının, hep istediği erkek çocukları, ikinci kadın doğurur. Anne ve kızlar erkek bebek olmasın diye dualar, beddualar ederler. Evde erkek bebeklerin varlığı Fadi'nin annesini ve kızları iyice silikleştirir. Ne var ki zaten kızlar on beş yaşına bastıklarında evlendirilirler. Artık en sona Fadi ve ondan bir büyük ablası kalır. Ablası ufak tefek olduğu için hemen evlenemez. Bu sırada, kederinden hasta olan annesine bakar. Fadi ise okula gitmektedir. Oldukça başarııdır ve okula devam etmek ister. Ablası ile hiç konuşamaz, çünkü ablası onu her seferinde azarlar. Bir gün geldiğinde ablasının intihar ettiğini öğrenir ve Fadi o gün kilitlenir. Ağlamaz, konuşmaz, yemez, içmez. Bu olay Fadi'nin kaderini değiştirir. Babası Fadi'yi iyileştirebilmek için şehre yatılı okula gönderir. Okulda çok başarılıdır, hep birinci olur. Eve dönüş onun için azaptır. Dönüşte annesinin 
öldüğünü de öğrenir. Ama yıllarca kızlarına da kendisine de hayatı zehir eden annenin ölüşü Fadi'yi sarsmaz. Hayata Dön eserindeki Ala karakterinin annesi ile ilişkisinin bir benzerini Fadi yaşamıştır. İkisinin annesi de mutsuz ve sevgisizdir. Çocukları sevgisizlik hatta nefret içinde büyür. Fadi'nin okuldaki başarısı kaderindeki ikinci dönümdür, Ankara'ya üniversiteyi burslu okumak için gider ve bir yandan okur bir yandan gece kulübünün ofisinde çalışır. Çalışma hırsı ve disiplinli başarısı sebebiyle gece kulübünde aranan biri olur. Kenan'la burada tanışır. Kenan'ın yakışıkııığının yanı sıra onun gücüne, gülüşüne âşık olur. Erkeklerden uzak duran, evlenmeyi hiç düşünmeyen Fadi; âşık olduktan sonra evli bir adamla, Kenan'la, on yıl birliktelik yaşar. Ancak Kenan onu, evliliğinin bittiğine inandırmış, evlenecekleri yolunda yalanlarla kandırmıştır. Önceleri Kenan onu kulüp görevlisi bir kız olarak görmüş, eğitimine yardım etmiştir. Ancak daha sonra Fadi'nin ondan uzak duruşu, onu elde edemeyişi Kenan'ı hırslandırmıştır. Okulu bittikten sonra gidecek yeri olamayan Fadi'ye Kenan bir ev döşemiş ve orada kalmasını sağlamıştır. Bunun ardından da ilişkileri başlamıştır. Fadi Kenan'ı kendinden çok çok üstün görür. Daima onun etrafında pervanedir. Çalışkan ve zekiliği sayesinde eğitimini ilerletir. İyi bir konumda çalışır. Ancak kendini gariban olarak görmeye devam eder. Geçmişiyle bağlarını koparır, sadece Kenan'la evlenme düşüncesi içindedir. On yıldır kandırılmaktadır. Bunu somut olarak gördüğünde ise travmatik bir kriz anı ile Kenan'ı sokak ortasında darp eder. Ardından intiharı dener. Doktora zorla getirildiğinde geçmişi tekrar su yüzüne çıkar. Onun kodlarında kendini sevdirme kabul ettirme isteği vardır. Çünkü doğal olarak olması gereken aile sevgisinden mahrum büyümüştür. Kendi kendini var etmiş, ancak sevgi açlığını yanlış adamda gidermeye çalışmıştır. Ne var ki artık mantığı bu yanlışı daha fazla ileriye götürmemiş ve ilişkisini sert bir şekilde sonlandırmıştır. Uzun süren bir aşk acısı çekmiş, aşkı nefrete dönüşmüştür, Kenan'dan sonra Doktora duygusal bağlanma yaşadığı için Doktor bunun önlemini almıştır. Fadi duruma üzülmüş ve tedaviyi yarım bırakmıştır. Bir müddet sonra iş yerinde ilerleyerek İstanbul'a taşınmıştır. Güven ve bağlanma sorunları nedeniyle tekrar bir ilişki yaşamamış, hayatını okumaya felsefeye adamıştır. Ailesi ile de iletişime geçmiş, üvey anne ve üvey erkek kardeşleri ile görüşmeye başlamıştır. Nihayetinde Kenan'ı da bağışlamış, onun huzurevinde kalması için finansörlük etmiş ve iç huzuruna kavuşmuştur.

Fadi'nin Kenan'ı bağışlaması, Kurtlarla Koşan Kadınlar adlı kitaptaki tam bağışlama şekliyle örtüşmektedir. Bu esere göre bağışlamanın dört evresi vardır: 1. Vazgeçmek, herhangi bir şeyle meşgul olmak (Fadi kendini işine vermiştir). 2. Kaçınmak, cezalandırmak ya da cezalandıııı sözlerden kaçınmayı içerir (Fadi Kenan'a beddua okumaktan vazgeçmiştir.). 3. Unutmak, olayın ön planda kalmasına izin vermeden arka plana geçmesini sağlamak, geriye bakmamak (Fadi Kenan'ı unutmasa bile uzaktan sadece izlemiştir.). 4. bağışlamak, esaslı olarak bağışlamaktır, suçlanan kişiye merhamet göstermek, bir şey beklememektir (Fadi, Kenan'ın pahalı huzurevinde kalması için gizlice finansörlük yapmıştır.) (Estes, 201: 406-409).

Fadi'nin annesi: Fadi'nin terapisi esnasında romana girer. Önce ezilmiş sonra ezen kadın rolündedir. Kocası ondan oğlan çocuk ister, son olarak Fadi'yi doğurduktan bir müddet sonra kocası onu ve kızları evden kovar. $O$ ise bütün suçu Fadi'ye yükler. Onu uğursuz olarak görür, zira erkek olsaydı kocası onu sevecek üstüne kuma getirmeyecekti. Ne var ki baba zaten eve 'boyalı, süslü, gülen, dans eden kadınlar' getirerek anneyi hiçe saymaktadır. Öte yandan anne hem evde çocuklara bakar, tarlada çalışan işçilere bile yemek yapar, dahası tarlada da çalışır. Üstelik akşamları dayak yer ardından baba onu yatağa çağııı ve sonrasında babayı yıkama görevini yapar. Tüm bunlar neticesinde öfkesini, hıncını kızlarından çıkarır. Özellikle evden kovulup döndüğünde evde kumayı görünce artık tümüyle öfkeden ibaret bir anneye dönüşmüştür. Kızları sürekli döver, özellikle kızlara, kocasına, kumasına ve üvey oğlanlara nefretle doludur. Kuma geldikten sonra kocası onu yatağa çağırmaz ama öldüresiye dövmeye devam eder. Artık evin işine karışmaz, onun tek işi kocasının dayağı ile işçilere yemek pişirmek olmuştur. Bir müddet sonra da kanser olur ve yatağa bağlı yaşar. Ancak oradan bile nefretini kusar. Yedi kız çocuk doğurmuştur, beşi yaşamıştır, yaşarken hiçbirine sevgi göstermemiş, hatta intihar eden kızına daha çok eziyet etse de onun ölümünün ardından sevgisini ölüye göstermiştir. Bu özellikleriyle güncel hayattan çok da uzak olmayan, kocasına her anlamda 
itaatkâr, dur durak bilmeden çalışan, emeği hiçe sayılan ancak yine de horlanan bir kadın profili görüyoruz. Koca, kadından hizmet ve erkek evlat beklemektedir. Başka hiçbir varlık sebebi yoktur. Kadın bu role ikna olmuş hatta kızlarını ezen role de girmiştir. Zira o hayatın içinde kız- kadın ezilmeye, sömürülmeye mahkûm bir hâldedir. Koca, hayatın çilesi, kuma ve kumanın erkek çocuk doğurmasıyla dünyası iyice daralan ve kararan anne tüm hıncını kızlarından çıkarır ancak vücudu buna daha fazla elvermez, kanser olarak yatağa bağlanır. Üç kızını evlendirip, bir kızını intihara kurban verip Fadi'yi de uzakta okumaya gönderince o da hayata gözlerini kapar. Böylelikle sevilmeyen, sevmeyen bir kadın daha toprak olur.

Kız kardeşini erken yaşta, koca şiddeti yüzünden kaybeden Tevfik Fikret Hemşirem için adlı şiirinde sadece kardeşinin değil, kadınlığın durumunu da anlatmış gibidir:

"Elbet değil nasîbi mezellet kadınlığın,

Elbet değil melekliğin ümmidi zulm ü şer;

Elbet sefîl olursa alçalır beşer

Lâkin bu gün hep onlara âit yı̆̆ın yığın

Endişeler, kederler, eziyetler, iğneler" (Kaplan, 2005:131).

Kuma Hanife: Kuma modeli için oldukça yerinde bir profil çizmektedir. Fadi'nin babasının tarlasında çalışan fakir ve mülayim bir kızdır. Âdeta kuma olmaya mecbur gibidir. O da bu durumu kabullenir, ancak kötü bir kuma olmaz, eve dönen kumasına ve kızlara iyi davranır yine de yaranamaz. Tam da istendiği gibi art arda oğlan doğurur ve baba onun sayesinde övünç duyar (!) zira babanın Allah'tan tek dileği oğlan çocuktur. Hanife kumasına hastayken çocuk gibi bakar, her isteğini yerine getirir. Yıllar sonra Fadi onu ve çocukları İstanbul'a getirtir ve böylelikle Fadi yıllardır özlemini duyduğu aile hasretini giderir.

Türklerde Aile başlıklı araştırmasında, Prof. Dr. İsmail Doğan, T.C. Anayasasının 41. maddesini delil göstererek, Cumhuriyet döneminin geçen tüm anayasalarında ilgili maddede öne çıkarılanın anne ve çocuk olduğunu ifade eder. Bu madde "Aile Türk toplumunun temelidir ve eşler arasında eşitliğe dayanır. " cümlesi ile başlasa da anayasa ile korunması beklenen anne ve çocuğun çeşitli travmalarla, bozuk bir düzen içinde ruh sağlıklarını silsileli bir şekilde kaybettikleri - incelenen roman ve öykülerdegörülmektedir (Doğan, 2013: 283).

Doktor Gülseren Budayıcıoğlu: Burada Doktoru bir hastalarının gözünden bir de kendi kaleminden tahlil etmeye çalışacağız.

Fadi ona ilk gittiğinde açılmak istememiş ama Doktor onu konuşturmayı, kodlarını çözmeyi, başarmıştır. Fadi'nin acıları ile birlikte acı çeken, onu anlayan sarıp sarmalayan bir doktor olmuştur. Hatta Fadi ile birlikte ağlamasına kendi kendine şaşırmış 'Ben doktorum, hasta ile ağlamak neyin nesi oluyor.' diyerek duygularını belli etmiştir. Fadi Kenan'dan arındıkça Doktoruna bağlanmaya, 'sahip' olarak Doktoru görmeye başlayınca Doktor bunu anlayıp Fadi'ye yaptığı yanlışı göstermiştir. Fadi ile ilişkilerinde Doktorun beklediği düzeyde bir ilerleme kaydetmişlerdir. Çünkü Doktor, mesleğini 'insana kendini affettirme sanatı' diye tanımlar. Fadi de terapi sonrasında çok düşünmüş, çok okumuş ve kendini affetmiş, hayattan memnun olmaya başlamıştır.

Kenan'ın psikiyatri doktorlarına gitmek gibi bir düşüncesi yoktur. Ancak karısı ve arkadaşları zoruyla birkaç erkek psikiyatra gitmiştir. Fakat aradığını bulamamıştır. Çünkü o iyileşmek değil, Fadi'yi kendisine döndürecek bir doktor aramaktadır. Hastalık hâli kötüleştiğinde, dünyaya âdeta keyif çatmaya gelen Kenan, hiçbir şeyden keyif alamamaya başlayınca kendiliğinden Doktor Gülseren Budayıcıoğlu'na gider. Sıra almak, beklemek gibi şeyleri düşünmeyen Kenan Doktora, doktor olarak değil kadın olarak bakar. Beğenince ve ilaç iyi gelince devam etmeye başlar. Öte yandan Doktora da diğer kadınlara davrandığı biri davranır. Onun için giyinip kuşanır, Doktor bu konuda titizlikle Kenan'ı uyarır ve asla bu yola girmesine 
müsaade etmez. Doktor Kenan'ı konuşturmaya çalıştıkça Kenan geçmişin önemli olmadığını iddia ederek kaçar, sorunu çözüp hayatını yoluna sokma konusunda hiç çaba sarf etmez. Doktorun sadece verdiği ilaçları kullanır, neden buraya geldiği ile ilgili düşünmez, Doktorun önerilerine kulak asmaz. Ancak Doktorun en son resti, Kenan'ı kendine getirir. Kenan'a göre Doktor önceleri sadece kadın, sonra güzel bir kadın oluşu ile vardır. Daha sonra ise ilaçları iyi gelen, iyi bir dinleyici olan Doktoru karşısında bulur. Ancak en nihayetinde Doktorun kendi üzerindeki hakkını günlüğünde yazar. $\mathrm{O}$, Kenan'a göre, hayatının sonuna kadar anlayış gösteren, dinleyen, yardım eden biri olarak hafızasında kalır. Doktora zorluklar çıkardığını kendi de itiraf eder. Ancak Doktor, yıllar süren bir izlemle onu takip eder. Gerektiğinde ücretsiz tedavi ve ilaç ile Kenan'ın elinden tutar. Sonunda ise ona hayatı sorgulatacak sorular sorarak düşündürür, son hamle ile Kenan'ın değişiminde rol oynar.

Kenan onu şöyle tasvir eder: "Gerçi o da çok resmi giyiniyordu. Etek ceket filan... Kendine erkeksi bir hava vermeye çalışsa de, kadın aslında çok çekiciydi. Hele biraz kabarık, kızııımsı saçlarına bayılmıştı. Sadece ses tonu, onu biraz rahatsız ediyordu. Hep emir verir gibi konuşuyor, arada bir de hafiften dalga geçer gibi gülüyordu. Ama yine de erkek doktorlardan daha fazla etkilenmişti ondan. Sanki o ne söylese. Öyle olacak gibi hissediyordu. Demek ki güveniyordu bu kadına." (Budayıcıŏ̆lu, 2016: 182).

Yazar, Doktor olarak birinci ağızdan eseri kaleme aldığı bölümlerde hem hastaları ve psikiyatri bölümünden bahseder hem de kendi hakkında, âdeta bir eser kişisi gibi, bilgiler verir. Bu bölümlerde hastalarla ilgili yorumlarını da buluruz. Bu bölümün ilkinde 'Yazar- Doktor' otuzlu yaşlarındadır. İşini, muayenehanesini, çalışma arkadaşlarını ve hastalarını sevmektedir. Kocası Aydın, çocukları Yağmur ve Hasan'la güzel bir aile tablosu içinde yer almaktadır. Eser içinde kendinden bahsederken kızıyla mutfak işlerini birlikte yapmaktan hoşlandıklarını, oğlunun ise teknik işler ve bilgisayarlarla ilgilendiğini belirtir. Kocası ile de sevgiye, saygıya dayalı bir ilişkilerinin olduğunu aynı zamanda çok yakışıklı bir adam olduğunu ifade eder. Yazar kendisini de seven bir kadındır. Güzel giyinmeyi, bakımlı olmayı sever. Hastalarına gösterdiği tavırla onların güvenini kazanır. Hastaları tedaviyi yarım bıraktığında içinde 'yenilmişlik, terk edilmişlik duygusu' oluşacak kadar hastası ile bütünleşmektedir. Öyle ki Doktor ailesine karşı hissettikleriyle hastalarına karşı hissettiklerini neredeyse eş tutar. "Ailem, bir de vazgeçemediğim sevgili hastalarım var. Eşime ve çocuklarıma duyduğum sevgi dolu sorumluluğun bir benzerini de hastalarıma duyuyorum. Belki de bunun için çok yorulsam da kırmızı renkli küçücük odamda akşama kadar çalışmak hep büyük zevk veriyor bana." (Budayıcıoğlu, 2016: 151).

Madalyon Kliniğin kurucusu olan Doktor, Türkiye'de alanında ilk olan bu kliniği kurma düşüncesine de roman içinde şöyle yer verir: "Bu kliniği kurarken tek hedefim ben bu dünyadan göç ettikten sonra arkamda, insanları şefkatle kucaklayan ve her dem onlara yardıma hazır bir ekip bırakabilmekti. Şimdi ise daha çok insana ulaşabilmenin peşindeyim, çünkü biliyorum, ülkemizde pek çok kişinin bu tür bir desteğe ihtiyacı var." (Budayıcıoğlu, 2016: 305).

Doktor, hastaları geçmişe dair konuştukça, onların şimdiki hâl ve hareketlerinin kodlarını çözer ve okuyucuya aktarır.

Eserde en çok Kenan'la olan ilişkilerine şahit olduğumuz Doktor, önce ona gerçekleri göstermeye çalışır ancak Kenan her seferinde kaçtığı için, Doktoru dinlemeden bildiğini okuduğu için, Doktor ona faydalı olamadığını düşünür. "Onu tanıyalı yıllar oldu ama o hâlâ ilk günkü gibi duruyor, hiç değişmedi, gelişmedi. (...) Ben de onu kırmamak, üzmemek için hiç sözünü kesmeden sabırla ve biraz da üzülerek dinliyorum. Artık konuşmaktan, ona yol göstermeye çalışmaktan çoktan vazgeçtim. $O$, bunları istemiyor. Şu sıralar kafasındaki hayalleri tekrar tekrar anlatabileceği bir dosta ihtiyacı var. Sonunda tam istediği gibi bir doktor oldum. Ne kadar yazık... (...) Kenan Bey'in anlattıkları dinlerken üzüleyim mi, kızayım mı bilemiyorum. Göz göre göre düştü bu hâllere. Çok zaman ve çok emek verdim ona ama hepsi boşa gitti. (...) bir yandan da düştüğü durumu gördükçe üzülüyorum. Öyle perişan ki... Hala ipe sapa gelmez hayaller peşinde. Onu bir 
türlü gerçekle yüzleştiremiyorum. Çaresizlik doktorları her zaman çok olumsuz etkiler. Bu adamın karşısında ben de kendimi çaresiz hissediyorum. Son zamanlarda vizite ücretini de ödemediği için çok dikkatli davranmaya çalışıyorum. Söylediğim şeyleri yanlış anlayabilir." (Budayıcıoğlu, 2016: 258, 260, 262). Doktor, Kenan karşısında kendini başarısız hissetmektedir ve bu duygudan kaçmak istediğini belirtir. Kenan'ın gerçeklerden kaçışını, yaşadığı olumsuzların sebebi olarak görmektedir. Yani Kenan her ne kötü durum yaşıyorsa bu, yaptıklarının bir karşılığı olarak önüne çıkmaktadır. Bu konuda Doktor-yazar şöyle söylemektedir: "Bana göre sistem, tıpkı Mevlana'nın dediği gibi karşılıklar esasına göre işliyor. Ne bir katre hayır karşılıksız kalıyor, ne de bir katre şer. Bu dünyada ne yaparsan, dünya er veya geç sana onun bir karşılığını mutlaka veriyor." (Budayıcıoğlu, 2016: 308-309).

Doktor kendi hayatından bahsettiği bölümlerden birinde acıyla tanıştı̆̆ından da bahseder. Eşinin hastalığı, kızının hamileliğinde çıkan sorunlar ve sonra eşini kaybetmesi yaşadığı derin acılardandır. Bu dönemi kendi kendine konuşarak, her türden kitaplar, özellikle tasavvuf ve felsefe okuyarak atlatmıştır. Acılarından da bir şeyler öğrenme peşine düşmüştür. Doktor gibi Fadi de kitaplara sığınarak kendini ve acılarını unutma yolunu tercih etmiştir. Psikolojide bibliyoterapi denen okuma sisteminde, kişi okuyarak kendini tedavi eder. Bu sağaltma sistemi çok eskiden beri mevcuttur (Öner, 2007: 135). Doktorun ve bazı hastaların bu yöntemi kullandığını görürüz. ${ }^{8}$

Sonsöz bölümünde Doktor hastaları ile âdeta söyleşir, kitabı yazma sürecinden bahseder. Kendinden bahseder. $\mathrm{O}$, umutsuzluğu, başarısızlığı sevmeyen, insanlara ve güzel şeylere olan inancını yitirmeyen bir kişidir. Edebiyata ve okumaya bağlıdır. Kenan'ı bir başarısızlık hikâyesi olarak yazmaya başlamış ancak Kenan'dan gelen günlük ile romanın sonu tümüyle değişmiştir. Yazar kendini 'her şeye meraklı' olarak tanımlar. İnanç sistemi ve bilimsel verilerle iç huzurunu sağlamıştır ve bunu hastalarına da okuyucularına da aktarır. Yine Sonsöz'de, mutlu olabilmek için başkalarını mutlu edebilmiş olmayı görmeyi diler.

Doktorun annesi: Doktor, annesine büyük bir sevgi ile bağııdır. Erken yaşta evlenmiştir. Evine, çocuklarına bağlı tipik bir Türk annesidir. Ancak kızına her zaman pozitif olarak, her şeyi yapabileceği inancı aşılamıştır. Sevgi ve inanç ile başarılamayacak bir şeyin olmayacağı düşüncesinin temelidir.

Tuna: Eserdeki en pozitif kişilerdendir. Doktor'un sekreteridir. Heyecanlı, neşeli biridir. Doktoru çok sever ve elinden geldiğince ona yardım eder. Hastalarla iletişimi iyidir. Doktor onu toplumun çekirdeği gibi görür, ondaki değişimi fark eder ve dikkate alır.

Semra: Bu kadın, eski Kenan'ın sonu gibidir. Kenan kıt kanaat, kiralık bir evde eski eşyaları ile yaşarken pastanede bu kadınla tanışır. Tuhaf şeyler giyen, çok konuşan garip bir kadındır. Çantasında üniversite diplomasıyla gezer, bir aşııı neşeli bir aşırı kavgacıdır. Çok zengin olduğunu, çocukları olduğunu söyler. Kenan'la samimi olurlar, beraber yiyip içerler. Kenan'ın evinden gerekli gereksiz bir sürü şey aşırır. Yalnızlıktan ölesiye korkan Kenan bu kadına bu hâli ile bile tahammül eder. Kadının aldığı çeşitli ilaçlar da vardır. Bipolar rahatsızığı yüzünden ağır bir nöbet geçirmektedir. Doktor, Kenan’a bu kadından uzak durmasını tehlikeli olabileceğini söylese de Kenan dinlemez. En sonunda Kenan'ın evini, o yokken tümüyle boşaltır ve ortadan kaybolur. Bu yüzden Kenan'ın giyecek elbisesi bile kalmaz.

Saliha: Kenan'ın hayatındaki son kadındır. Ama öncekilerden çok farklıdır. İri yarı, güçlü bir köylü kadınıdır. Huzurevinde bahçıvanlık yapmaktadır, kocasını, oğlunu, gelinini trafik kazasında kaybetmiştir. Kötürüm kalan torununa bakmak için çok uzak mesafeden yürüyerek çalışmaya gelir. Kenan'a bahçe işlerini öğretir. Hayatını, torununu anlatır. Kenan çocuğa yürekten bağlanır ve ona önce tekerlekli sandalye, sonra ameliyat sonra iyi bir ev ve eğitim masraflarını karşılamak için elinden gelen her şeyi yapar. Öldüğünde emekli maaşı kadına ve torununa kalsın diye, kadınla kâğıt üstünde evlenir. Bu kadın normalde eski

\footnotetext{
8 Psikiyatrist Irvin Yalom, Bugünü Yaşama Arzusu adlı kitabında bibliyoterapi ile hayatını değiştiren bir kişiyi konu alır.
} 
Kenan'ın asla bakmayacağı tipte biridir, ancak Kenan'ın değişim derecesini göstermesi bakımından romanda önemli yere sahip olduğunu söyleyebiliriz.

Eserde fon figür olarak şu kadınları da sayabiliriz: Fadi'nin kız kardeşleri ve arkadaşları, Gülay, Handan'ın arkadaşı Özlem, Öğretmen Serap, Şoför İsmail'in karısı ve kızı, Kenan'ın hayatındaki geçici kadınlar...

Kitap konu olarak şu temel bölümler üzerinden ama bölümler birbiri içine girmiş bir şekilde ilerlemektedir. Önce Kenan ve Fadi'nin birlikte hayatları, sonra Fadi'nin travması ve Doktor'a gelişiyle onun hayatı, Kenan'ın ayrılık sonrası yaşadıkları ve Doktora gelişi, Kenan'ın düşüşü, Kenan'ın dönüşümü.

Eser teknik yapı bakımından farklı bir görünüm arz etmektedir. Şöyle ki: Yazarın, üçüncü tekil kişi ağzından olayları ilâhî bakış açısı ile anlattığı bölümler 1'den 21'e kadar uzanmaktadır. Aralarında ise 'Doktorun Günlüğünden' başıılı 14 bölüm vardır. Burada yazar- Doktordur. Birinci tekil şahıs ağzından, gözlemci bakış açısı ile olaylar ele alınır. Eserin sonunda ise Kenan'ın günlüğü ile karşılaşııı. Artık eser kahramanı kendi hayatını kendi dilinden anlatır. Böylelikle üç anlatıcı ve farklı bakış açıları ile örülü bir roman ortaya çıkar. Roman örgüsü sona erdikten sonra yazar "Sonsöz" ile okuyucuları ile iç dünyasını paylaşır, kendinden bahseder ve son olarak da "Teşekkür" ile başta Kenan'a ve hayatında olan herkese teşekkür ile eserini bitirir.

Eserde Kenan'ın varlığı kadınlar üzerine kurulmuştur. Kenan kadınları çok sever, aynı zamanda da duygusal olarak incitir. Bu davranış şeklini incelediğimizde, feminist hareketin öncülerinden Fatma Aliye'nin 1913'te kaleme aldığı "Hukuk- I Nisvan” yazısındaki sözlerin değeri anlaşılmaktadır: "Kadınlar erkeklerin enis-i canı imiş, refik-i ömrü imiş, aklın, iz'anın mütemmimi, yuvanın nâzımı, idarenin nazırı velhasıl şerik-i hayatı imiş, daha bilmem ne imiş! Bunların hepsi yalan! Muharrirlerin bu tarif ve tavsifleri yalan olmakla beraber ince olan hissiyatımızı ihtizaza getiriyor, bizi aldatıyor. Bu aldanma yüzündendir ki hukukumuzu müdafaa edemiyor, daima erkeklere âtıl bir esir kalmışız. İnsanların dünyada şüyu bulduğu zamanlardan beri hal bu minval üzeredir. Erkek, kadın daima ayrı ayrı hayat takip etmiştir. Biz zavallı kadınlar, erkekler nazarında daima bir meyve bir meta halindeyiz. Amelimiz, hakk-ı hayatımız tahdit edilmiştir. Hem de hiçbir zaman tam manâsıyla erkeklere enis-i can, refik-i ömr, şerik-i hayat olamadık. Yuvamızın nâzımı, idaremizin nazırı dahi değiliz. Biz kadınları daima ayrı bir 'daire-i hayat' içinde sıkmışlar, erkeklere esir mahkûm eylemişler." (2015: 59-60).

\section{Bulgular}

İncelenen dört eserde, genelde toplum, özelde aile içinde kadının çok çeşitli sorunlarla yüz yüze geldiği görülmektedir. Kadının sadece var oluşu bile kimi zaman rahatsız edici kabul edilmiş, kadın reddedilmiş, suçlanmış, aşağılanmıştır. Öte yandan bu olumsuz davranışlar kadına önce aile içinden, özellikle annebabası tarafından uygulanmışsa, kadının özgüven eksikliğinde ve birey olma yolunda kapatılamayan açıkları olduğu görülmüştür. Eşleri tarafından psikolojik ve fizyolojik istismara uğrayan kadınlar ise, bu durumlarını yıllarca kabullenmiş, problem kemikleştikten sonra psikolojik destek almak zorunda kalmışlardır. Tüm eserleri, kadın sorunu açısından tek bir noktada toplamak gerekirse; kadının, hatta insanın sevgi, merhamet gibi insanî duygulardan yoksun olarak yaşamasının, onu nasıl bir yıkıma götürdüğü, gerçek hayat hikâyelerinden yola çıkılarak anlatılmıştır.

Kızlarını baskı altında tutan ailelerin genelde onları koruma amacı vardır. Ancak amaç baskılayıcı bir şekle dönüştürse kötü sonuçlar doğurmaktadır. Zafer Toprak 1908-1935 yılları arasında Türkiye'de Kadın Özgürlüğü ve Feminizm adlı çalışmada belirttiği üzere, Cumhuriyet ile çeşitli özgürleri artan kadınların bu özgürlüklerini kullanmayışlarını bilememelerinden kaynaklanan ruhsal bozukluklar veya intihar vakalarının varlığı bilinmektedir. Bu yüzden aileler kızları için endişelenir. "Kadın disiplin altına alınmalı, kontrol mekanizmaları kadının mizacını şekillendirmeliydi. Ağaç yaşken eğilirdi. Kızını dövmeyen dizini döverdi. 0 
nedenle daha büluğ çağında gerekli disiplin ihdas edilmeli, genç kızken doğru yola çekilmeliydi. Aşk onun için bir 'altın tuzak'tı. Genç kız bir an önce yuva kurmalı, çoluk çocuk sahibi olmalıydı. Kadın ancak aile yuvasıyla kimlik kazanabilirdir. Seksüalite genç kızı baştan çıkarır, büluğ buhranı genç dimağları Bakırköy'e, bimarhaneye, akıl hastanesine kadar sürükleyebilirdi." (2015: 372-374). Kızlarını korumak uğruna eve kapatan annelerin kızlarının, evden kaçtığı, intihar ettiği, Budayıcıoğlu’nun eserlerinde de görülmektedir.

Kadının, eşine yakınlığı ile kendi değerini belirlediği üç öykü kişisi benzer duygular içindedir. "Binbir Gece Masalı"ndaki Nihal Hanım, "Internette Aşk Başkadır"daki Jale Hanım ve "Kırık Hayatlar"daki Reyhan Hanım evliliklerinde eşlerini çok severler. Ancak aynı ilgiyi göremediklerinde önce hayal kırıklığına uğrar sonra da psikolojik olarak rahatsızlanırlar. Bu konuda "Türkiye'de, eşine yakın olma duygusu, kadınlar için büyük değer ifade etmektedir." (2001: 290) diyen Kırkpınar'ın görüşünün haklıı̆ı̆ını buluruz.

Kadınların hemcinsleri ve karşı cins tarafından gerek duygusal gerek fiziksel şiddete uğraması tarih boyunca var olmuştur. Ancak Fatmagül Berktay'ın da ifade ettiği gibi, bu ezilmeye sistemli bir karşı çıkış yoktur (2003: 89). Budayıcıoğlu'nun eserlerindeki kadınların pek çoğu ekonomik özgürlüğüne sahip ya da maddi gücü yerinde olan kadınlar olmasına rağmen herhangi bir hak arayışı ya da sistemli bir yapı içinde mesela feminist duruş ile kendilerini korumaya alacak girişimde bulunmamaları dikkat çekicidir.

Kadınlı̆ı̆n en çok sömürülenleri olan hayat kadınları, incelenen eserlerde karşımıza çıkmıştır. Bu kadınlardan ikisi: "Kader Kurbanları" öyküsündeki Hayal ve "Günahın Üç Rengi" öyküsündeki Hayat fahişeliğin, kadınların kendi tercihi olduğunu ifade etse de "Fahişeliğin Rengi Kırmızı" öyküsünde Meliha'nın annesi ve ablasının bu yolu tercih etmedikleri buna zorlandıkları bilinmektedir. Bu konuda hayatın gerçeğinde de Saylan şu ifadelere yer verir: "Bir gençkızın fahişeliğe itilmesinde yalnızca içinde bulunduğu kötü aile koşullarının, ruhsal yapısının ve ekonomik durumunun sorumlu olmadığını, çevresindeki insanların da bu yönlendirmede büyük rolü olduğunu ve başlangıçta olayların çocuk veya gençkızın isteği dışında geliştiğini görürüz." (1995: 284). Nitekim fahişeliğin ayrıntılarından bahseden bu kadınlar ev baskısından kurtulmak için sevdiği gençlere kaçmış, sonradan bu batağa saplanmışlardır. Öte yandan Meliha'nın annesi ve ablası ise köyde tecavüzlere maruz kalmışlar ve buna karşı koyacak herhangi bir güç bulamamışlardır.

Öykü içlerinde ve özellikle Hayata Dön romanında şiddet ciddi bir uyarıcı olarak karşımıza çıkmaktadır. Fiziksel ya da sözel şiddetin yer aldığı bu eserlerde bu durumun normalleştirilmesi olayın vahametini artırmaktadır. "Toplumsal şiddette en büyük tehlike, şiddetin içselleştirilmesi, gelecek nesillere aktarılması ve bu süreç içerisinde, kalıcı ve doğal sayılmasıdır. Çocukluğunda şiddeti bir terbiye biçimi olarak yaşayan ve algılayan bireyler, genellikle aynı yöntemi kendi çocukları için tercih ederler ya da şiddete maruz kaldıklarında bunu kendi suçlarının doğal sonucu olarak kabul ederek içselleştirirler." (Balkır, 2013: 211). "Ev içi şiddet, aile içi şiddet olarak da adlandırılmaktadır. (...) Şiddetin karşıdakine, sadece fiziki olarak güç kullanmak suretiyle onu darbetmek şeklinde değil, aynı zamanda istem dışı, sözlü ve psikolojik baskı şeklinde karşıdakini rahatsız etme olarak görülmesinin daha doğru olacağını düşünmekteyiz. Böyle bir tanım içerisinde, şiddet, içinde özgürlüklerin ve hakların kısıtlanmasını barındıran bir davranış biçimi olarak algılanmalıdır." (Öztürk, 2011: 15-16). Aile Araştırma Kurumunun yaptırdığı araştırmaya göre Türk kadını çeşitli şiddet biçimlerine maruz kalmaktadır. Yüzde 84 ile sözel şiddet (hakaret) ilk sırayı alırken yüzde 78.9 ile fiziksel şiddet (dayak) ikinci sıradadır. Bunları sırası ile duygusal şiddet (tehdit, yüzde 29.3), ekonomik şiddet (parasal, yüzde 17.5), cinsel şiddet (zorla ilişki, 9.1) takip etmektedir. Şiddetin sebepleri ise yine çeşitlidir. "Maddi güçlükten kaynaklanan sorunlar, kocanın aşııı sinirli olması, kocanın akrabalarının kışıırtmaları, kocanın aşııı alkol kullanması, sudan sebepler, belli ir neden yok, kadının dikbaşı olması, kocanın aşırı kıskanç olması" şiddete maruz kalanın belirttiği sebeplerdir. (Aile İ̧̧i şiddetin Sebep ve Sonuçları, 1995: 140, 143). 
Gerçek hayat hikâyelerinden oluşan bu eserler esasen toplumsal gelişim haritamızın bir parçasına ışık tutmaktadır. "Bir toplumun ne denli medenî bir yapıya sahip olduğu kadınların toplum içindeki görüntüsü ile ölçülebilir. Ne var ki kendi kültürel ve tarihî derinliklerindeki yüksek medeniyetleri ile övünen çok ileri toplumlarda bile kadın ve kadının kültür hayatı tartışma konusu olamayacak kadar yetersizdir." (Akşit Kuşcan, 2015: 173). Türk toplumunda en eski çağlardan günümüze doğru kadının konumu ve değeri incelendiğinde kültürel alt yapımızın analizi de bu doğrultuda yapılmış sayılacaktır.

\section{Sonuç}

Psikolojik çözümlemeleri esas alan bu kitaplarda kadınların iç dünyalarını iki farklı açıdan okuyarak kadın gerçeğinin kişisel ve toplumsal olarak nasıl yükler altında kaldığına şahit olduk. Kadın varlığını sadece edebiyat temelli değil psikolojik vaka olarak incelediğimizde, karşımıza çeşitli şekillerde kadın tipleri çıkmaktadır. Yazar bir psikiyatrist olarak, insanı anlamayı vazife edinmiş ve insanın kendini anlamasına ve affetmesine yardımcı olmuştur. Profesyonel işi haricinde bunları gizli klinik dosyalarından çıkarıp edebî bir bütünlük ve kurmaca içinde yazar olarak edebî dünyaya katmıştır. Genelde yazarlığına, özelde tipoloji yaratısına baktığımızda, Budayıcıoğlu başarılı bir çizgide ilerlediğini görmekteyiz. Çünkü karakter ve tip yaratmada ilk kitabından son kitabına kadar gelişerek değişmiştir. Kitaplarını tür ve tarz olarak incelersek, ilk kitabı, kısa öykülerden oluşur. Eser kişileri daha yalın kat oluşturulmuştur. Bu, kısa öykü türünün üzerinde taşıdığı bir özellik olarak da değerlendirilebilir. ikinci eseri uzun öykülerden oluşur. Eserler arasında beş yıl vardır. Ancak yazardan öğrendiğimize göre, bu beş yıl yazar açııından, yoğun ve acılarla geçmiş̧ir. İkinci eserde kişilerin ve olayların, biraz daha detaylandııılığını görmekteyiz. Eserlerin kurgusu da ilkine göre daha edebî bir hâl almıştır. Üçüncü eser romandır, ancak içinde kısa öyküler barındırmaktan uzak durmaz. Çünkü bu ilk üç eserde Doktor, aynı zamanda birinci tekil ağızdan olayların anlatıcısıdır. Bu yüzden roman içinde asıl olay ve kişiye geçerken, onun öncesindeki hastalardan bahseder. Onların hikâyeleri ile romanı besler. Son eser ise tümüyle bir edebî roman görünümdedir. Yazar yukarıda ifade ettiğimiz gibi farklı edebî teknikler de kullanmıştır. Tekniklerin yanı sıra hayattan aldığı kişileri artık fiktif kişi hâline getirmekte daha başarılıdır. Kişiler fiziksel özellikleriyle detaylıca çizilmiştir. Zaten ruhsal özelliklerine apaçık bir ayna tutulmuştur ve bunlar anlatılırken, olayın örgüsündeki bağlar koparılmadan yapılmıştır. Yazarın genel tutumu kişileri önce fiziksel sonra ruhsal özellikleri ile anlatmaktır. Bu tarz, aynı zamanda hastalarını incelerken kullandığı bir metottur. Kendisine gelen kişiyi gözlerinden, yüz çizgilerinden ellerine, kıyafetlerine, taktığı aksesuarından kokusuna kadar detaylı bir şekilde inceler. Sonra yürüyüşü, mimikleri devreye girer. En sonunda da önce konuştuğu yüzeysel konuları, sonrasında bilinçdışının karanlıklarında kalan bilgilere ulaşıp kişiyi öyle analiz eder. Mesleğinde yıllarca kullandığı bu tekniği eserlerinde de kullanarak edebî örüntüyü kurmuştur.

Dört eserdeki kadınların sorunlarını belli başlı odak noktalarda toplayabiliriz. Öncelikli olarak en büyük eksiklik sevgidir. Bir kadın sevildiğini hissetmediği bir ortamda asla mutlu olamaz. Özellikle bu küçüklüğünden gelen bir sorunsa, yetişkinliğinde de aşamaz. Çünkü sevgiyi, tanıması gereken dönemde tanımamıştır. Aile bu konunun içinde sadece sevgiyi sağlayan asıl kaynak olarak görülür. Ailede başlayan, çözümlenemeyen her konu yetişkinlikte patlamaya hazır bir sorun olarak zihinlerde taşınmaktadır. Kız çocuklarının karşılaştıkları sorunlardan başlıcası, erkek olarak doğmamalarıdır (!). Bu ise kadının kendini sevmemesine esas teşkil eder. İkinci olarak, tanımadığı erkeklerle görücü usulü evlenmeleridir. Üçüncüsü ise aile içindeki baskı ve şiddettir. Evlilik sonrasında ilk soruna yine dönülür, bu kez kadın erkek çocuk doğuramadığı için suçlanır. Evlilikle gelen başka bir sorun kıskançıktır. Kadının kendi namus kavramından ziyade, kocanın namus anlayışı etkindir. Kocalar eşlerine en küçük yersiz bir şüphe şiddet uygular. Kadının karşılaştı̆̆ı en büyük handikap hem duygusal hem fiziksel şiddettir. Çocukken şiddete alıştırılanlar haricinde, psikanaliz biliminin kurucusu Freud ve yazar Budayıcıoğlu kadının bilinçdışını suçlar. Kadın içindeki yerli yersiz suçlanmayı bastırma yöntemi dayak yemek, kendini başkası elinden cezalandırmaktır. 
Kadın sadece kocadan hasar almaz, baba da bu konuda etkindir. Hatta hayatındaki en önemli erkekten, babadan, dayağı öğrenen kadın evlendikten sonra kocasından da bunu bekler. Kadın sadece erkekten şiddet görmez, anne de bu konuda yaralayıcı olmaktadır. Annesinden bu muameleyi gören çocuklar, kendi çocuklarına da benzer şekilde davranmaktadır. Çocuğu şekillendiren annenin yaptığı her hata, ileriye dönük, daha büyük bir hatanın habercisidir. Anne çocuğunu büyütürken aşırı korumacı davrandığında da sorunlu bir çocuk yetişmektedir. Cinsel kimlik bulma evresinde benzer şekilde, annenin katı tutumu çocukları cinsel sapkınıklara da yöneltebilmektedir.

İnsanlığın daima arzuladığı sağlıklı bir toplum hayatı için, önce aileyi kuran kadına hak ettiği değerin verilmesi gerekmektedir. Çocukluğunda ötelenen, ileride sözlü ya da bedensel şiddete maruz kalan bir genç kızın, evlendiğinde sağlıklı bir eş ve anne olmadığı görülmektedir. Sevgi ile büyütülmeyen kızlar kendi ailelerini kurduklarında çeyizlerinde sevgisizlerini de getirmekte ve miras olarak çocuklarına aktarmaktadırlar. "Sevgi ve hoşgörü" felsefesi yaşam biçimine dönüştürülmedikçe, yaşam alanlarında huzurlu ve sağlıklı topluma kavuşmak uzak bir hayaldir. Ancak Türk İslâm kültüründe, bozulmamış Anadolu geleneklerinde, tasavvufî felsefede, "sevgi ve hoşgörü"nün her şeyin esasına yerleştirildiğini görebiliriz. Özünde bunları taşıyan milletlerin, öfke, nefret gibi kabuklarından sıyrılması hasretle beklenen bir durumdur. Doktor Gülseren Budayıcıoğlu, hastaları ile ilişkisinde tam da bu felsefeyi yaşatan kişi olarak görülür. Hasta kendini ne kadar bağışlanmaz ve sevimsiz hissetse de, o, profesyonel doktor kimliği ile hastasına gerekli olan her şeyi sevgi ve hoşgörüsü ile aktarmıştır.

Kadını kendi tarihini çocukta yazan kişi olarak değerlendirebiliriz. Yazımızı kadınları anlamadığı itiraf eden Freud'un "Dişilik" konferansını bitirdiği sözlerle bitirelim: "Eğer dişilik hakkında daha fazla şey öğrenmek isterseniz kendi yaşam deneyimlerinizi sorgulayınız ya da şairlere yöneliniz ya da bilim size daha derin ve daha tutarlı bilgi verebilinceye dek bekleyiniz." (Freud, 1998: 150). Ne var ki hâlâ bilim de sanat da kadınlar hakkında tutarlı ve kesin bilgi vermekten yoksundur.

\section{Kaynakça / References}

Abadan, Unat N. (1982). Toplumsal Değişme ve Türk Kadını. Türk Toplumunda Kadın. (s. 1-32). Ankara: Araştırma, Eğitim ve Ekin Yayınları.

Akşit, Kuşcan Ö. (2015). Lilith'den Malala'ya Kadının Adı Var. İstanbul: Puslu Yayıncılık.

Balkır G. Z. (2013). Kadın Çalışmasında Ayrımcılık ve Cinsel Taciz, (Tekcan M.) Kadın Kitabı. (s. 205-250). Kocaeli: Umuttepe Yayınları.

Berktay F. (2003). Tarihin Cinsiyeti. İstanbul: Metis Yayınları.

Budayıcıoğlu, G. (2016). Kral Kaybederse. ìstanbul: Remzi Kitabevi.

Budayıcıoğlu, G. (2017a). Madalyonun Içi. İstanbul: Remzi Kitabevi.

Budayıcıoğlu, G. (2017b). Günahın Ü̧̧ Rengi. İstanbul: Remzi Kitabevi.

Budayıcıoğlu, G. (2018). Hayata Dön. İstanbul: Remzi Kitabevi.

Cebeci, D. (1993). Tanzimat ve Türk Ailesi. İstanbul: Ötüken Neşriyat.

Doğan, İ. (2013). Türklerde Aile. (C. Öztürk Ed.). Türk Tarihi ve Kültürü (s. 267-285). Ankara: Pegem Akademi. 
Estes, C. P. (2017). Kurtlarla Koşan Kadınlar. (Atalay H. Çev.). İstanbul: Ayrıntı Yayınları.

Fatma, Aliye (2015) Hukuk-ı Nisvan, (H. Osmanağaoğlu) Feminizm Kitabı Osmanlı'dan 21. Yüzyıla Seçme Metinler. (s. 58-60) Ankara: Dipnot yay.

Freud, S. (1963). Cinsiyet ve Psikanaliz. (S. Hilav Çev.). Ankara: Varlık Yayınevi.

Freud, S. (1981). Dostoyevski ve Baba Katilliği. (S. Hilav Çev.). Psikanaliz Açısından Edebiyat (s.5-32). Ankara: Dost Kitabevi Yayınları.

Freud, S. (1998). Ruhçözümlemesine Yeni Giriş Konferansları. (E. Kapkın- A. Kapkın Çev. ) İstanbul: Payel Yayınevi.

Jung, K. G. (1981). Psikoloji ve Edebiyat. (S. Hilav Çev.). Psikanaliz Açısından Edebiyat (s.53-78). Ankara: Dost Kitabevi Yayınları.

Kaplan, M. (2005). Tevfik Fikret, Devir- Şahsiyet- Eser. İstanbul: Dergâh Yayınları.

Kırkpınar, L. (2001). Türkiye’de Toplumsal Değişme ve Kadın. Ankara: Kültür Bakanlığı.

Moran, B. (2004). Edebiyat Kuramları ve Eleştiri. İstanbul: iletişim Yayınları.

Öner, U. (2007). Bibliyoterapi. Journal of Art and Sciences. Sayı: 7.

Öztürk, E. (2011). Feminist Teori ve Tarihsel Süreçte Türk Kadını. İstanbul: Rağbet Yay.

Sartre, J.P. (1982). Edebiyat Nedir? (B. Onaran Çev.). İstanbul: Payel Yayınları.

Saylan, T. (1995). Kadın Ticaret ve Zorla Fuhuş (N. Arat) Türkiye'de Kadın Olgusu. (s. 273-290). İstanbul: Say Yay.

Tarhan, N. (2009). Kadın Psikolojisi. İstanbul: Nesil Yay.

Toprak, Z. (2015). Türkiye’de Kadın Özgürlüğü ve Feminizm (1908-1935). İstanbul: Tarih Vakfı Yurt Yay.

Türkiye Cumhuriyeti Başbakanlık Statüsü ve Sorunları Genel Müdürlüğü (2001). Türkiye'de Kadın 2001. Ankara.

Türkiye Cumhuriyeti Başbakanlık Aile Araştırma Kurumu (1995), Aile İ̧̧i Şiddetin Sebep ve Sonuçları, Ankara.

Üskül, Engin Z. Ö. (2008). Hukuk Sosyolojisi Açısından Türkiye'de Evlenmenin Evrimi. İstanbul: Beşir Kitabevi.

Yılmaz, A.K. (1998). Erkek ve Kadında Eşcinsellik. İstanbul: Özgür Yayınları.

Yalom, I. (2002). Bağışlanan Terapi. (Z. İyidoğan Babayiğit Çev.) İstanbul: Kabalcı Yayınevi.

Yalom, I. (2007). Bugünü Yaşama Arzusu Schopenhauer Tedavisi. (Z. İyidoğan Babayiğit Çev.) İstanbul: Kabalcı Yayınevi. 